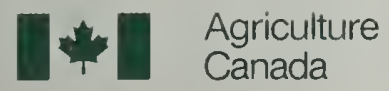

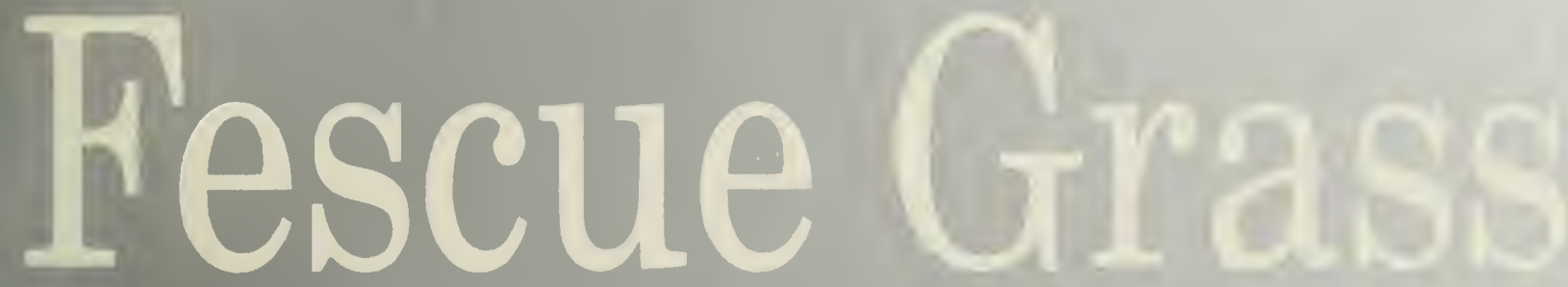

\title{
of Canada
}

I*I Aagrature SEP 111990

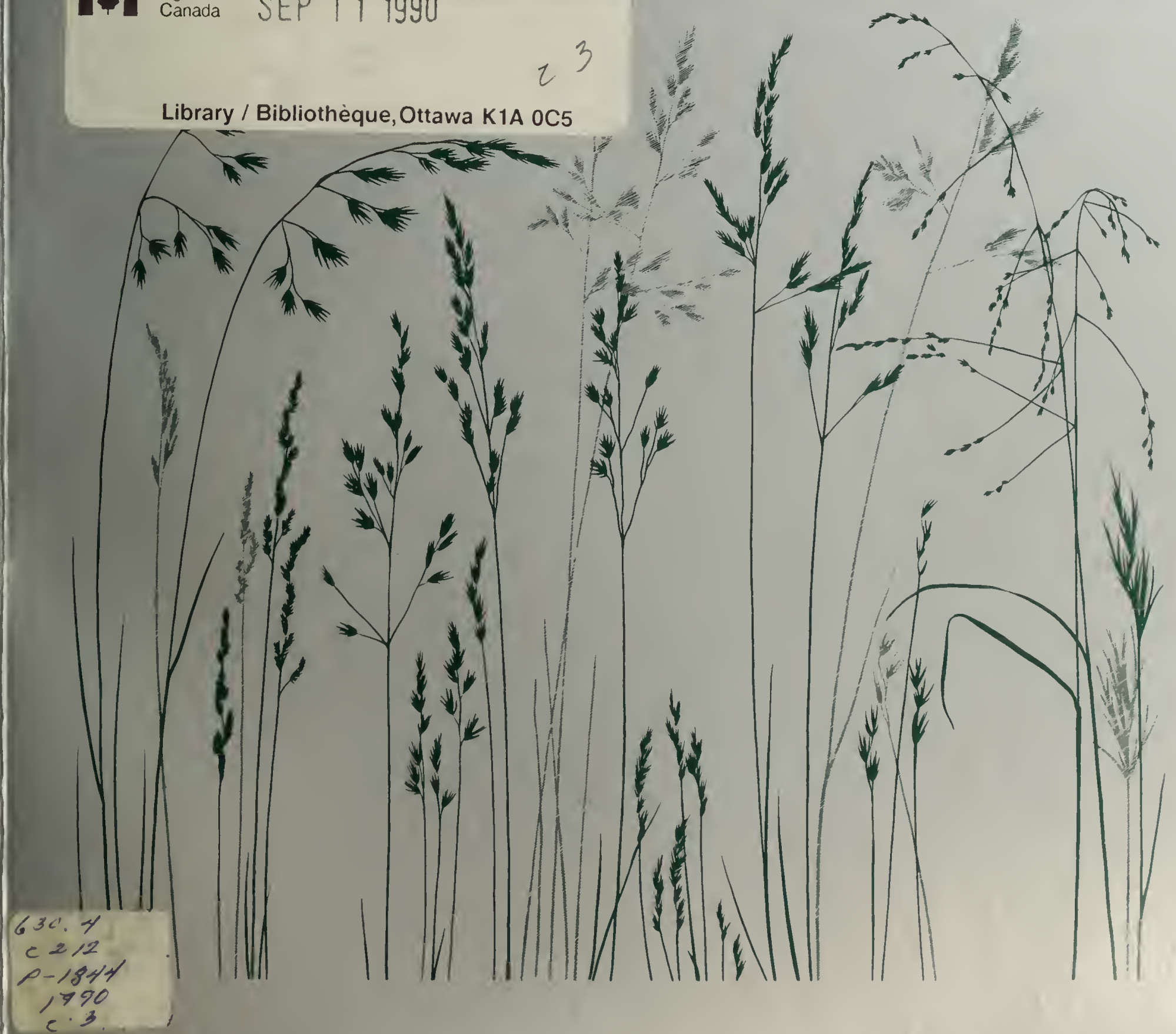





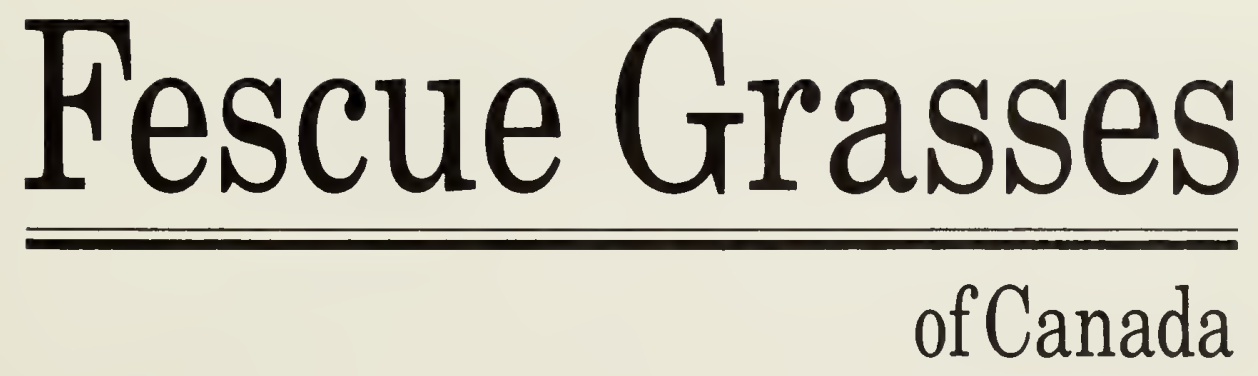




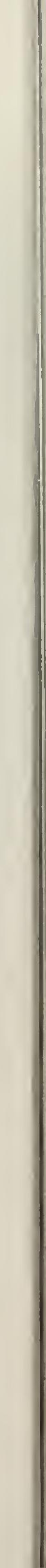




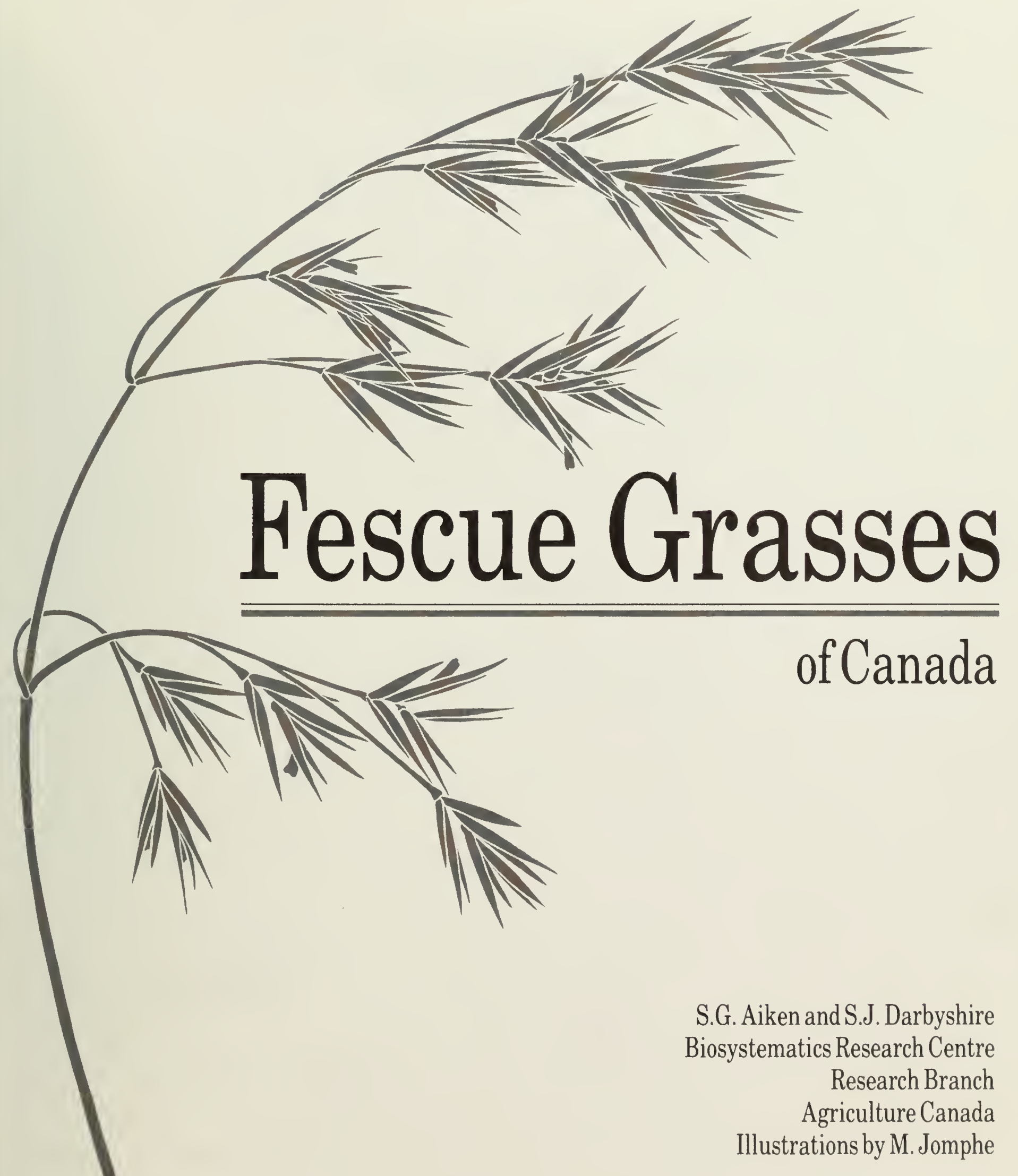

Publication 1844/E 
- Minister of Supply and Services Canada 1990

Available in Canada through

Authorized Bookstore Agents

and other bookstores

or by mail from

Canadian Government Publishing Centre

Supply and Services Canada

Ottawa, Ont. Canada K1A 0S9

Catalog No. A53-1844/1990E

ISBN 0-660-13483-7

Canadian Cataloguing in Publication Data

Aiken, S. G.

Fescue grasses of Canada

(Publication ; 1844/E)

Includes bibliographical references.

Cat. No. A53-1844/1990E

ISBN 0-660-13483-7

1. Fescue--Canada. I. Darbyshire, S. J. II. Canada. Agriculture Canada. III. Title. IV. Series:

Publication (Canada. Agriculture Canada). English ; 1844.

QK495.G74A34 $1990 \quad 584 / .9 \quad$ C90-099105-4

Illustrator: M. Jomphe Staff editor: Jane T. Buckley 


\section{Contents}

Acknowledgments iv

Abstract/Résumé v

Introduction 1

Economic importance 1

Phytogeography 1

Taxonomy: the genus 1

Taxonomy: the species 2

Hybrids 3

Vegetative proliferation or pseudovivipary 4

Relationships with fungi 5

Materials and methods 7

Results and discussion 9

Use of characters in identification 9

DELTA 11

Generic description 13

Key to species 14

F. altaica 21

F. arundinacea 23

F. baffinensis 27

$F$. brachyphylla 29

$F$. brevissima 31

F. campestris 33

$F$. filiformis 35

$F$. gigantea 37

$F$. hallii 39

$F$. hyperborea 41

$F$. idahoensis 43

$F$. lenensis 47

F. minutiflora 49

$F$. occidentalis 51

$F$. pratensis 53

$F$. richardsonii 55

F. rubra 57

$F$. saximontana 61

$F$. subulata 65

F. subuliflora 67

F. subverticillata 69

F. trachyphylla 71

$F$. viridula 73

$F$. vivipara 75

Concluding remarks 78

Collection sites: Maps 1-25 79

Literature cited 97

Appendix 103

Index 109 


\section{Acknowledgments}

The authors ${ }^{1}$ thank M. Kerguélen (Universidad Autonoma, Madrid, Spain), I. Markgraf-Dannenberg (retired, Botanischer Garten und Institut für Systematische Botanik der Universität Zürich, Switzerland), H. Salvensen (Botanisk Institutt, Universiteti Oslo, Norway), and S. Frederiksen (Institute for Systematic Botany, Copenhagen, Denmark) for most helpful discussions and some annotations on Festuca species occurring in Europe as well as in Canada; P. Morisset and M. Dubé (Laval University, Quebec), J. Looman (retired, Agriculture Canada Research Station, Swift Current, Sask.), V. Harms (University of Saskatchewan, Saskatoon), S. Smoliak (retired, Agriculture Canada Research Station, Lethbridge, Alta.), L.E. Pavlick (Royal British Columbia Provincial Museum, Victoria), B.M. Brooke (Agriculture Canada Research Station, Kamloops, B.C.), and A. Roberts (Williams Lake, B.C.) for specimens, information, discussions, and insights into Festuca occurring in Canada; W.J. Cody and J. Cayouette (Biosystematics Reseach Centre, Agriculture Canada, Ottawa, Ont.), R.I. Hamaguchi (Ottawa, Ont.), W.J. Crins (New York State Museum, Albany), L. Maus (University of Windsor, Ont.), S.G. Klumph (retired, Public Lands Division, Lethbridge, Alta.) for living collections of Festuca; J. Reese and K. Upton (Plant Research Centre, Agriculture Canada, Ottawa, Ont.) and G. Gazendam (National Museum of Natural Sciences, Ottawa, Ont.) for assistance in maintaining the living plants; M.C. Goffinet (New York State Agricultural Experimental Station) for discussion on the interpretation of sheath development. Thanks are also extended to illustrator M. Jomphe (Biosystematics Research Centre) and editor Jane T. Buckley (Research Program Service) for their special contributions.

1 S.G. Aiken's present address:

Botany Division, Canadian Museum of Nature,

P.O. Box 3443, Station D, Ottawa, Ont. K1P 6P4 


\section{Abstract}

Twenty-four species are described in the grass genus Festuca (Poaceae) in Canada, of which six species are introduced and naturalized. One species, red fescue ( $F$. rubra), has both native and introduced forms.

Taxonomic literature, morphology, and ecology are discussed. A key to the species and species accounts are presented. Species accounts include partial synonymy, descriptions, distribution, chromosome counts, illustrations, dot distribution maps (for Canada) and comments on taxonomic problems, subspecific taxa, and ecology.

\section{Résumé}

Dans cette publication, on fait la description de vingt-quatre espèces du genre Festuca (Poaceae) que l'on trouve au Canada dont six introduites ou naturalisées. Une espèce, la fétuque rouge ( $F$. rubra), a les deux morphotypes, indigène et introduit.

On y fait en outre un exposé sur les publications taxonomiques, la morphologie et l'écologie. On y trouvera également un tableau d'identification et des commentaires sur les espèces. Pour chaque espèce, on retrouve une liste partielle de la synonymie, une description, une aire de répartition, des dénombrements chromosomiques, des illustrations, une carte de répartition pour le Canada et des notes sur les problèmes taxonomiques, les sous-espèces et l'écologie. 
Digitized by the Internet Archive in 2012 with funding from

Agriculture and Agri-Food Canada - Agriculture et Agroalimentaire Canada 


\section{Introduction}

\section{Economic importance}

The name Festuca L. comes from an old Latin word meaning a weedy grass. In Canada, native or introduced Festuca species are known generally as beneficial plants but sometimes are considered as weeds (Crompton et al. 1988). One or more species directly affects the life of almost every Canadian. Homeowners are familiar with the virtues of the lawn grasses creeping red and Chewing's fescue. These and other commercial forms of red, tall, and hard fescues are commonly seeded for land stabilization on such places as roadsides, parks, deforested areas, ski slopes, sports fields, and along pipelines. Livestock owners in the East use red, hard, meadow, and tall fescues; in the West, plains, rough, Rocky Mountain, and Idaho fescues are important rangeland grasses. Throughout Canada various species are important as wildlife forage. Coarser species, such as tall fescue, are sometimes considered weeds of fine-textured lawns. The United States Department of Agriculture index to available cultivars for 1972 listed 42 fescues and an artificial hybrid variety ( $X$ Festulolium Ascherson \& Graebner). Duke and Terrell (1974) listed six species of Festuca (all occurring in Canada) among the world's 1000 most important crop plants.

\section{Phytogeography}

The genus Festuca contains an estimated 450 species (Clayton and Renvoize 1986). They occur in polar, temperate, and alpine regions of both hemispheres. Within Canada the genus is distributed from Masset, B.C., to St. John's, Nfld., from the high arctic tundra to the temperate rain forests, and from intertidal marshes to alpine barrens. The genus is represented in all major floristic zones by different species adapted to, and largely restricted by, different environmental conditions.
In the West, species that occur more widely in the United States extend their range into southern Canada. For example $F$. subulata Trinius in von Bongard and $F$. subuliflora Scribner in Macoun occur in the forests of British Columbia; $F$. viridula Vasey and $F$. idahoensis Elmer are found in open grasslands. Species found in high arctic and alpine habitats include $F$. baffinensis Polunin, $F$. brachyphylla Schultes \& Schultes fil., $F$. brevissima Jurtzev, $F$. hyperborea Holmen ex Frederiksen, $F$. lenensis Drobov, and $F$. minutiflora Rydberg. Members of the rough fescue complex (section Breviaristatae Krivot) are dominants in fescue grasslands from British Columbia to Manitoba. Festuca subverticillata (Persoon) Alexeev is a common grass in wet and mesic forests of southeastern Canada. Some species have remarkably disjunct distributions. For example, $F$. altaica Trinius in Ledebour is widespread in the Yukon, Northwest Territories, and northern British Columbia and has disjunct populations in Quebec and Newfoundland. Another example is $F$. occidentalis Hooker, which occurs mainly west of the Rocky Mountains but also has populations around the Great Lakes region.

Introduced species, although widely distributed across the country, are particularly common in eastern Canada. Their adventive distribution will undoubtedly increase with increased use and the breeding of varieties having greater drought or cold hardiness.

\section{Taxonomy: the genus}

The genus Festuca, with its more or less rounded lemmas and linear hilum, represents one of the main evolutionary lines in the tribe Poeae. This large and ancient group (Tzvelev $1971,1972 a$ ) has given rise to a number of minor segregates showing more advanced characteristics such as annual habit, racemose inflorescence, and fertile spikelets with sterile associates. The abundance of small genera 
centred around the large genus $F$ estuca indicates unresolved inconsistencies in the application of the generic concept in Poeae (Clayton and Renvoize 1986). Although superficially similar to some Festuca, the genus Bromus L. (section Pnigma Dumortier) is readily distinguished by the pubescent apical ovary appendage and subterminal styles. The high number of characters variable at the generic level is apparent from various generic descriptions (Clayton and Renvoize 1986, Watson et al. 1986, Watson and Dallwitz 1988).

The first major monograph on Festuca was that of Hackel (1882), Monographia Festucarum Europaearum. Piper (1906) compiled the first extensive treatment for North America. He followed Hackel's delimitation of the genus for the most part but included subgenus Vulpia (C.C. Gmelin) Hackel. Hitchcock (1935) and Hitchcock and Chase (1951) treated these annuals as section Vulpia (C.C. Gmelin) Reichenbach and this treatment has been followed in many North American works. Although Vulpia C.C.

Gmelin and Festuca species have been shown to hybridize (Barker and Stace 1982, Ainscough et al. 1986), the annual habit, usually cleistogamous florets and the one to three short anthers (less than $0.5 \mathrm{~mm}$ ), distinguish Vulpia from Festuca. The latter is perennial and has chasmogamous florets and three large anthers (mostly more than $0.5 \mathrm{~mm}$ ). These differences are now considered to be sufficient to justify the recognition of two genera (Lonard and Gould 1974). This delimitation of genera has also been adopted by Bews (1929), Fernald (1950), Tzvelev (1976), Gould and Shaw (1983), Markgraf-Dannenberg (1980), Clayton and Renvoize (1986), and Watson and Dallwitz (1988).

The subgeneric classification of North American Festuca proposed by Alexeev (1980) is listed with Canadian species:

Subgenus Obtusae Alexeev: F. subverticillata Subgenus Subulatae (Tzvelev) Alexeev:

Section Subulatae Tzvelev:

$$
\text { F. subulata }
$$

Subgenus Subuliflorae Alexeev:

F. subuliflora
Subgenus Schedonorus (Beauvois)

Peterman:

Section Schedonorus (Beauvois) Koch:

$F$. arundinacea, $F$. pratensis

Section Plantynia (Dumortier)

Tzvelev: $F$. gigantea

Subgenus Leucopoa (Grisebach) Hackel:

Section Breviaristatae Krivot:

$F$. altaica, $F$. campestris, $F$. hallii

Subgenus Festuca:

Section Festuca:

$F$. baffinensis, $F$. brachyphylla,

$F$. brevissima, $F$. filiformis,

$F$. hyperborea, $F$. idahoensis,

$F$. lenensis, $F$. minutiflora,

$F$. occidentalis, $F$. richardsonii,

$F$. rubra, F. saximontana,

$F$. trachyphylla, $F$. viridula,

F. vivipara.

\section{Taxonomy: the species}

Early species concepts within the genus Festuca were very broad, especially within $F$. ovina L. as treated by Hackel (1882) and Saint-Yves (1925). Many taxa, previously recognized as infraspecific in $F$. ovina, are now generally regarded as species. Sheep fescue ( $F$. ovina) has often been cited in the Canadian flora generally referring to the native species, such as $F$. saximontana Rydberg, $F$. brachyphylla or $F$. idahoensis, or the introduced $F$. trachyphylla (Hackel) Krajina. European $F$. ovina L. sensu stricto may have been distributed in Canada with early seed mixtures, but it is not known to have naturalized and is not considered in this treatment.

The F. rubra L. complex occurs throughout Canada. In southeastern areas it is often dominant in pastures and fields and is an important forage. The taxonomic situation has been complicated by widespread selective breeding and introduction of cultivars into Canada from around the world. It is suspected that in this outcrossing species at least some interbreeding of native and introduced members has occurred. Duyvendak et al. (1981) after a detailed study of 59 red fescue 
commercial cultivars in Europe found that each of the many characteristics considered showed continuous variation with the exception of chromosome number. These workers recognized three cultivar groups: hexaploid noncreeping, hexaploid creeping, and octoploid creeping red fescues. They concluded that these three groups do not coincide with any of the described taxa. Festuca richardsonii Hooker, here treated as a species but often referred to $F$. rubra ssp. arctica (Hackel) Govoruchin, and some of the infraspecific taxa recognized by Pavlick (1985) may have merit though they form a continuum within the $F$. rubra complex and are not always recognized by authors.

Of the 24 species recognized as occurring in Canada, Scoggan (1978) included 19 of these taxa, recognizing 10 species with 23 infraspecific taxa. Since Scoggan (1978) several other publications have appeared that are relevant to taxonomic problems in the genus in Canada. For example, the number and level of the taxa recognized in the rough fescue complex has been studied by Alexeev (1982), Aiken and Lefkovitch (1984), Pavlick and Looman (1984), and Harms (1985). Work has been done on the red fescue complex (Dubé et al. 1985, Pavlick 1985, Dubé and Morisset 1987, Aiken et al. 1988 ) and on the $F$. ovina complex (Frederiksen 1978, 1979, 1981, 1982, 1983; Pavlick 1983a, b, $c, 1984)$. There have also been some more general treatments (Alexeev 1980, 1982, 1985; Dore and McNeill 1980; Aiken et al. 1985).

This study was undertaken to incorporate recent work and to summarize infor mation on this taxonomically difficult group in Canada. In this treatment we have recognized 24 species, about half of which are widely accepted as good species, about a quarter are generally accepted, and the remainder are presented tentatively as their taxonomy is still the subject of debate and in need of further research.

\section{Hybrids}

Naturally occurring hybrids within the genus Festuca and with species of other grass genera have not been reported in Canada, although some have been reported from Eurasia. The economic value of fescues has encouraged many breeding programs and artificial hybrid studies. Some forage grass varieties of hybrid origin have been developed such as Kemal and Prior ( $F$. pratensis Hudson $\times$ Lolium perenne L.). Those natural and artificial hybrids involving Festuca and reported for pairs of grasses known to occur in Canada are listed.

Combinations for which binomials have been published are followed by a dash and the name. None of these hybrids have as yet been reported for Canada.

Festuca arundinacea

$\times F$. gigantea $-F . \times$ gigas Holmberg

$\times F$.rubra

$\times$ Bromus erectus Hudson-

$\times$ Bromofestuca cojocnensis Prodan

$\times$ Bromus ramosus Hudson

$\times$ Lolium multiflorum L.

$\times$ L. perenne- $\times$ Festulolium holmbergii (Dörfler) P. Fournier

ssp. arundinacea $\times F$. gigantea $-F$.

$\times$ flischeri Rohlena

ssp. arundinacea $\times F$. pratensis ssp. pratensis $-F$. $\times$ aschersoniana Dorfler var. fasciculata Sonder $\times F$. gigantea $-F$. $\times$ moyana Erdner

Festuca filiformis

$\times F$.pratensis

$\times$ F.rubra

$\times$ Lolium perenne

Festuca gigantea

$\times F$. pratensis ssp. pratensis $-F$.

$\times$ schlickumii Grantzow

$\times F$. pratensis ssp. apennina (De Notaris) Hegi-F. $\times$ czarnohorensis Zapalowicz

$\times F$. rubra

$\times$ Bromus arvensis L.

$\times B$. inermis Leysser

$\times$ Lolium multiflorum Lamark$\times$ Festulolium nilssonii Cugnac \&

A. Camus

$\times$ L. perenne- $\times F$. brinkmannii (A. Brown) Ascherson \& Graebner 
Festuca pratensis

$\times F$. rubra-F. X herocynica Wien

$\times$ Bromus erectus Hudson

$\times B$.ramosus

$\times$ Glyceria fluitans (L.) R. Brown

$\times$ Lolium multiflorum-X Festulolium braunii (K. Richter) A. Camus

$\times$ L. perenne $-\times$ Festulolium loliaceum (Hudson) P. Fournier

$\times$ L. temulentum L. $-\times$ Festulolium colini Cugnac \& A. Camus

$\times L . \times$ hybridum Haussknecht $(=L$. perenne $\times$ L. multiflorum)

Festuca hyperborea

$\times F$. vivipara

Festuca richardsonii

$\times F$. vivipara

Festuca rubra

$\times F$.trachyphylla

$\times$ Lolium multiflorum

$\times$ L. perenne- $\times$ Festulolium fredericii Cugnac \& A. Camus

$\times$ Vulpia bromoides (L.) S.F. Gray

$\times$ V. myuros (L.) C.C. Gmelin

ssp. arctica $(=F$. richardsonii)

$\times F$. vivipara

\section{Vegetative proliferation or pseudovivipary}

Virtually all fescues, and many other grasses (Beetle 1980), are capable of producing leafy bulbils or plantlets in place of the floral bracts. This structure is a modification of the vegetative tissue of the flowering shoot and, although it may include one or more staminate flowers, it is not, as the term "vivipary" suggests, the germination of a seed in situ. Plants with stressed physiology are prone to produce such structures through the disruption of hormonal regulation. Various environmental factors are implicated in the initiation of proliferation including predation, disease, moisture levels, nutrient levels, photoperiod, herbicides, and seasonal climate. Vegetative proliferation is often seen in fescues both in the field and in cultivation; in most cases, it is the result of temporary physiological disruption of flowering.

In some fescue plants the production of plantlets is constant as a result of disruption to the genetic control of sexual reproduction. Cytological studies suggest that many of these plants are hybrids, and either allopolyploids or autopolyploids (Löve and Löve 1956,

Frederiksen 1981). The genetic disruption of sexual reproduction has occurred many times in some populations of fescues. The red fescues in eastern North America have given rise to some highly adaptive clones that continue to grow and spread solely by plantlets produced by vegetative proliferation or by rhizomes. These clones, which may cover extensive areas, generally occur in slightly different habitats to the nonproliferating forms.

Selection in arctic, boreal, and alpine areas is rigorous and many plants producing remarkably well-developed plantlets are found in such habitats. Harmer (1984) suggested that vegetative proliferation in such habitats may be an adaptive alternative to sexual reproduction in unpredictable short-season environments. He pointed out that Scottish forms of $F$. vivipara (L.) Smith are rarely wholly proliferous but occasionally produce sexual organs. However, neither Festuca vivipara nor $F$. rubra forma prolifera (Piper ex Robinson) Hylander are known to produce seed. The success of these widely ranging forms is the result of selection of the most fit clones from a polyphyletic range of genotypes.

Despite the large number of studies on the production of leafy structures in grass spikelets (Arber 1934; Nygren 1950; Wycherley 1953a, b; Moore and Doggett 1976; Harmer and Lee 1978; Frederiksen 1981; Harmer 1984; Aiken et al. 1988; and others) many problems remain in interpreting the process in relation to species limits (compare Frederiksen 1981, Alexeev 1985, and Aiken et al. 1988). The genus Festuca displays a bewildering variety of these leafy forms, which have confounded attempts to reconcile the requirements of a phylogenetic yet practical taxonomy. 


\section{Relationships with fungi}

Sixty-seven species of pathogenic or decay fungi have been identified from at least nine Festuca species in Canada (Conners 1967, Ginns 1986). Some are problems not only for the plant but also for herbivores. Ergot

(Claviceps purpurea (Fr.) Tul.) epidemics often occur locally, attacking grasses and sedges. This fungus attacks the developing fruits and forms a large, hard sclerotium in place of the grain. Generally black in color, they may also have purple, white, or pink patches. They are spherical to irregularly cylindrical and curving in shape and are larger than uninfected grains.

Fungi in the tribe Balansiae are well known on a variety of grass hosts (Diehl 1950, Clay 1988). Some species are systemic endophytes whereas others are epiphytic on surfaces of immature tissues. The Balansiae are closely related to Claviceps Tul. and also produce toxic ergot alkaloids. The best known of the endophytic fungi is Epichloe typhina (Pers.) Tul. (anamorph: Acremonium coenophialum Morgan-Jones \& Gams) which commonly occurs in F. rubra (Sampson 1933), F. arundinacea Schreber (Bacon et al. 1977), and other grasses (Diehl 1950, White 1987, Clay 1988). Recent studies have shown a number of endophyte fungi in species of Festuca (Latch et al. 1984, 1987; White and Cole 1985, 1986; White et al. 1987). These fungi affect the hosts in many ways. Endophytes that produce toxins have been shown to provide protection for their hosts from predation (see review by Clay 1988). This problem can be serious to grazing animals where pastures are dominated by infected grasses. Intoxication occurs at very low concentrations and is called "summer syndrome" (in cattle grazing $F$. arundinacea) or "rye-grass staggers" (in sheep grazing Lolium perenne). Depression in the performance of grazers is highly variable but is significant at moderate rates of infection. Although we have detected some endophytes, they do not seem to represent a significant problem in Canada. Mitigation of toxicosis by providing other forage species greatly reduces performance depression. Initial infection by endophytes appears to be rare. Pastures seeded with endophyte-free varieties of tall fescue will remain free of infection as long as infected seed does not invade from nearby areas. 


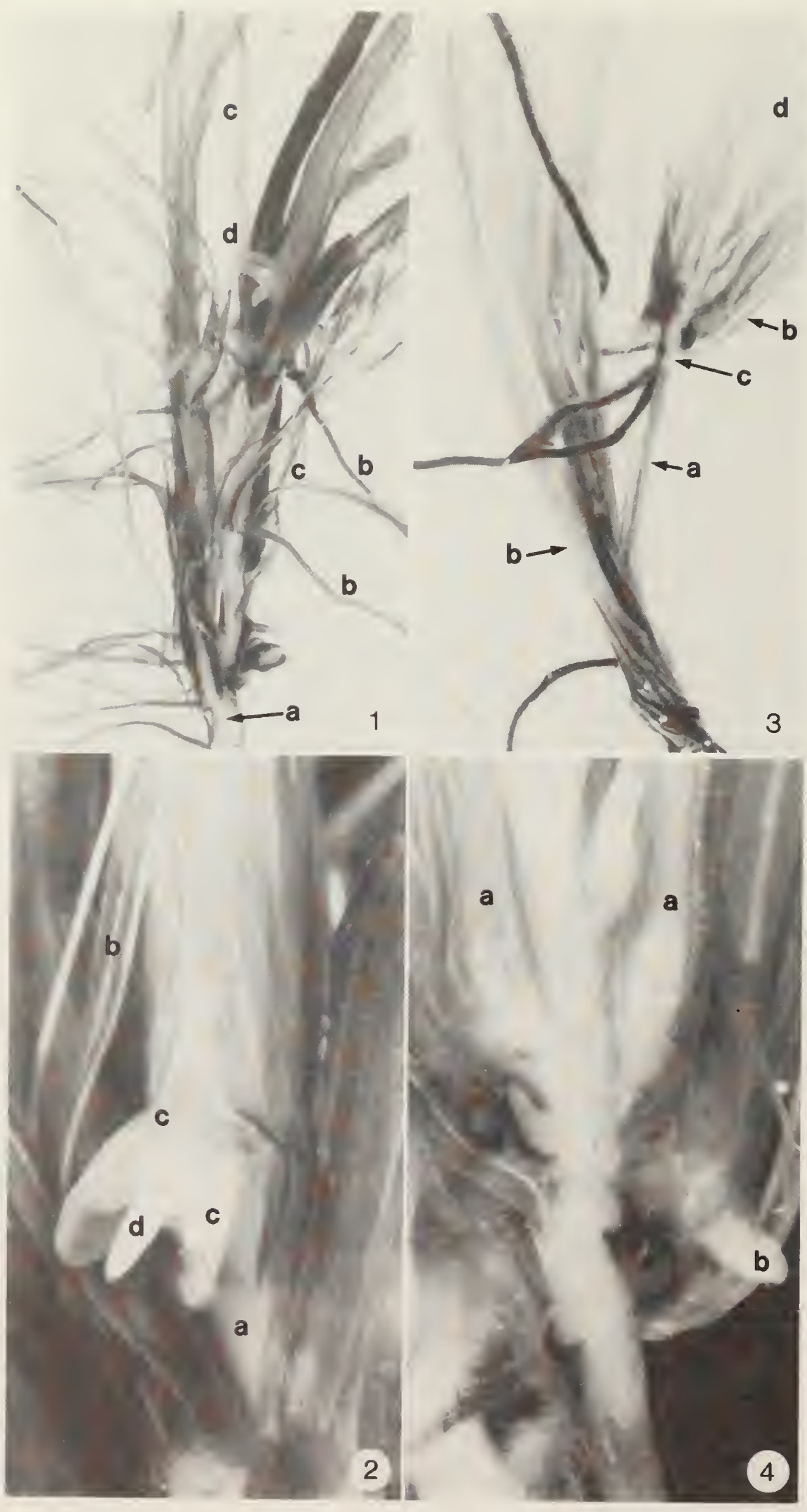




\section{Materials and methods}

This treatment is based on literature survey, correspondence and discussions with many workers (particularly those mentioned in the acknowledgments), field work, cultivated material, and an examination of the Festuca collections at the herbaria of the Canadian Museum of Nature (CAN) 1 and the Biosystematics Research Centre, Agriculture Canada (DAO) with selected material from ALTA, BM, BRY, C, F, GH, GGB, K, MICH, MTJB, NY, OXF, PHIL, QF, QFA, SASK, SCS, UBC, US, WIN, WYA, and Z. Data were gathered in DELTA format following the techniques described by Watson et al. (1986) and using the characters listed in the Appendix and illustrated in Plates 1-5. Measurements in the species accounts given in brackets are values found in the literature or are rarely encountered in Canadian material. Anatomical characters were recorded as described in Aiken et al. (1985). Leaf descriptions apply to mature leaves of vegetative shoots unless otherwise stated. Lemma characters refer to the lower lemmas in the spikelets. Chromosome counts given in boldface have been reported from Canadian material. Distribution maps were prepared primarily from specimens at CAN and DAO (see Maps 1-25 under "Collection sites"). Only synonyms commonly used in North American and, in particular, Canadian references are listed. Extensive synonymy listing may be found in Alexeev (1985). Detailed listing of subspecific names has been omitted, although subspecific concepts are discussed when deemed appropriate.

Illustrations of each species (see Plates 6-30) were compiled in standard format for ease of comparison. The following features are illustrated for all species: whole plant habit (A) at various scales; the junction of leaf sheath and blade (B) at $12 \times$; leaf cross section (C); an enlarged portion of the inflorescence (D) at $2 \times$; glumes $(G)$ (not always shown) at $8 \times$; lemma $(\mathrm{L})$ at $8 \times$; palea with pre-anthesis anthers $(\mathrm{P})$ at $8 \times$; and ovary $(\mathrm{O})$ at $40 \times$. Other special features illustrated are accompanied by a scale bar. When available, living plants were used for the whole plant drawings.

The key to species was constructed to incorporate identification difficulties rather than to hide them with simplified dichotomies. Many confirmatory characters have been given to strengthen the accuracy with difficult, incomplete, or immature specimens. Read the options carefully and use as many of them as possible until you are familiar with the groups. Identification will become easier with increasing experience, although it is rarely a simple matter, even for "experts."

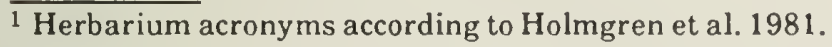

1 Plate 1 Emergence of new shoots.

$(1,2)$ Festuca rubra showing extravaginal shoots: (1) Base of plant showing a rhizome branch $(a)$ between tillers; roots $(b)$ arising at nodes along the rhizome; fibrillose strands (c) from fraying leaf sheaths; prophyll surrounding an extravaginal bud $(d)$ bursting through the leaf sheaths at the base of the culm (about $3 \times$ ). (2) Enlargement of $(d)$ in 1 showing inner $(a)$ and outer (b) sheaths split open between the vascular bundles by the emerging new shoot $(c)$; the first emergent leaf $(d)$ and surrounding prophyll (c) (about $21 \times$ ).

$(3,4)$ Festuca saximontana showing intravaginal shoots: (3) Base of plant showing stem internode $(a)$; leaf sheaths $(b)$ not fraying into fibers; tiller $(c)$ with upper portion longitudinally sectioned to show new shoots surrounded by sheath bases (about $3 \times$ ). (4) Enlargement of $(c)$ in 3 , longitudinal section through a developing tiller showing shoots $(a)$ developing within surrounding sheaths; root (b) pushing through the bases of the sheaths (about $14 \times$ ). 


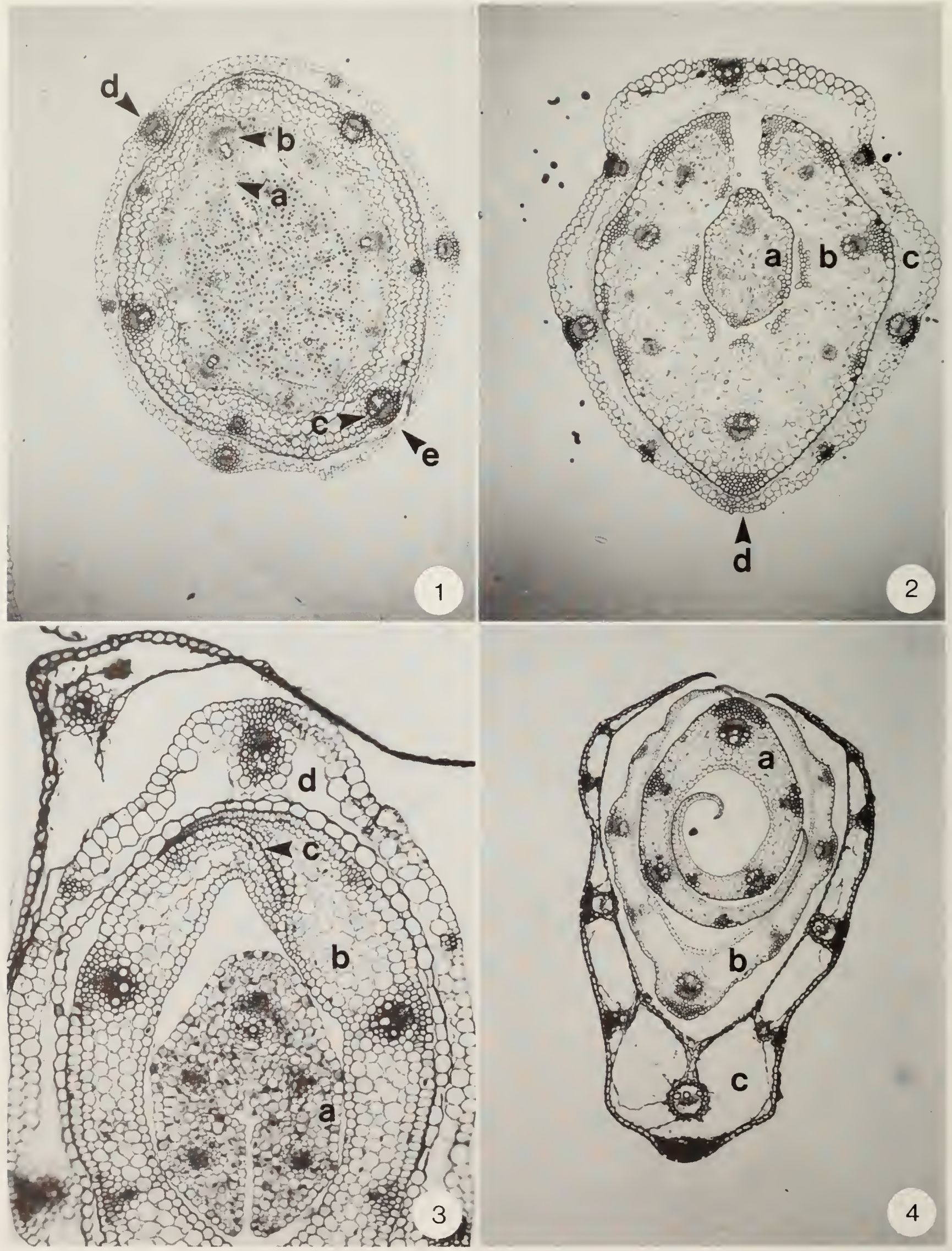




\section{Results and discussion}

\section{Use of characters in identification}

Plant color was found to be of little use, because color differences can be seen within single populations of several species in the field and because color commonly changes on dried herbarium specimens. Plant height can be useful in distinguishing the smaller from the larger species but must be used with caution. Height may vary in adjacent plants growing in apparently identical conditions (see $F$. idahoensis and $F$. saximontana accounts) and is subject to many macro and microenvironmental conditions. The habit at the base of the plant is useful if specimens are properly prepared. A densely tufted habit may be induced in plants whose growth is confined by rocks. The vivid purple color in new shoots was found to be quite variable. Purple coloration is rare in the sheaths of arctic fescues many of which have very purple inflorescences.

The lack of exposed culm nodes in the rough fescue complex is a useful feature to distinguish them from other species such as $F$. saximontana and $F$. idahoensis, which generally have at least one culm node visible. It is a character to be used with caution in small arctic or alpine fescues.

The extravaginal and intravaginal shoot conditions (Plate 1) are useful characters but may be difficult to interpret in highly compact plants or scanty specimens.

The anatomical differences in closed and open sheaths are shown in Plate 2. When old, a closed sheath splits between the vascular bundles as growing leaves within the sheath expand. An open sheath develops a distinct separation zone and opens up in this position, like a split ring, that can yield to pressures of growing leaves within. Whether a sheath does or does not lay down a separation zone is determined at the growing apex within the sheath base (Sharman 1945). The extent to which open sheaths are open (the proportion of the sheath with separated margins) is not only difficult to determine but was found to be highly variable.

Sheaths were found to be not keeled in most Canadian Festuca, although, in some, the larger mid vein may appear to form a keel in pressed specimens. Sheath persistence is usually a conspicuous and useful character, especially

Plate 2 Cross sections of developing leaf sheaths to show the open and closed sheath conditions.

$(1,2)$ Festuca rubra showing closed sheath development: (1) Cross section towards the base of a developing shoot showing margins $(a)$ of a central developing leaf; midribs of successively older sheaths $(b, c, d)$; a split $(e)$ in the outer (older) sheath opposite its midrib; the three rows of parenchyma cells of the innermost sheath are compact, those of the middle sheath are larger and, in places, tissue degeneration has begun (i.e., the middle row of parenchyma cells is disintegrating) and the outer sheath contains only a single layer of parenchyma underlying the outer (dorsal) epidermis (about $6 \times$ ). (2) Cross section towards the top of a developing sheath showing a central, very young, leaf $(a)$ with a developing midvein and sclerenchyma thickening beginning opposite the midvein and at the leaf margins; a well-developed leaf (b) surrounded by a mature sheath (c) that has no separation zone $(d)$; the position opposite the sheath midvein (d) has no vascular bundle and no marginal sclerenchyma thickening, suggesting that, as the inner leaves expand, they are most likely to split the sheath in this position first as in $1(e)$ (about $6 \times 1$ ).

$(3,4)$ Festuca saximontana showing open sheath development: (3) Cross section towards the base of a sheath showing a central developing leaf $(a)$, surrounded by an inner sheath $(b)$ with four or five rows of compact parenchyma tissue between the upper and lower epidermi and a separation zone (c) seen between the midveins of the leaf and outer sheath $(d)$; the dark line of the separation zone may be cuticular material; the outer sheath $(d)$ has large spaces and only one row of parenchyma cells remaining; (about $16 \times$ ). (4) Cross section through three leaf sheaths showing successive development. The innermost sheath $(a)$ has compact parenchyma and the overlapping margins allow considerable expansion in response to pressure from developing leaves within (not seen). The middle sheath $(b)$ margins just overlap, and disintegration of parenchyma between the vascular bundles has occurred; the margins of the outer sheath (c) do not overlap and almost no parenchyma tissue remains intact, with only the vascular bundles, bundle sheaths, and sheath extensions remaining (about $8 \times$ ). 
with sheaths of $F$. rubra that rapidly fray into fibers with senescence (fibrillose, Plate 1, Fig. 1). Many of the bunchgrass fescues, such as the rough fescues, have sheaths described as marcescent (Plate 1, Fig. 2), where the dead leaf sheaths remain intact and persist to form a palisade-like fascicle around the base of the plant. Sheath pubescence is a variable character in some species such as $F$. lenensis, $F$. trachyphylla, and $F$. rubra. The presence of retrorse (downward pointing) hairs on a fraying sheath is a good indication that the specimen is likely $F$. rubra.

The clawlike auricles at the top of the sheaths of $F$. arundinacea, $F$. pratensis, and $F$. gigantea (L.) Villars are an excellent indication of subgenus Schedonorus. Whether or not the auricle position has a distinct erect swelling (see Fig. B on Plates 14 and 20 for $F$. hallii (Vasey) Piper and $F$. pratensis Hudson, respectively) or is rounded (see Fig. B on Plates 15 and 19 for $F$. hyperborea and
$F$. occidentalis, respectively) was used by Howarth $(1924,1925)$ but may vary on different parts of the plant.

Anatomical characters of the leaf blade cross section (Plate 3 ) and their taxonomic use and limitations were studied by Aiken et al. (1985). The dimensions, extent, and position of schlerenchyma and rib characters can be useful in assisting identification.

The shape and position of trichomes (hairs) on the inflorescence rachis branches are sometimes distinct but may also vary with the position in the inflorescence and between specimens. This character is of limited use.

The presence of trichomes between the veins (keels) of the palea, palea vestiture, (Plate 4, Figs. 1-3) are visible with magnification $(10 \times)$. The palea of $F$. subverticillata (Plate 4, Figs. 4-6) has minute silicious bumps and appears glabrous.

Most lodicules in Festuca have a fleshy basal portion that swells at the time of anthesis

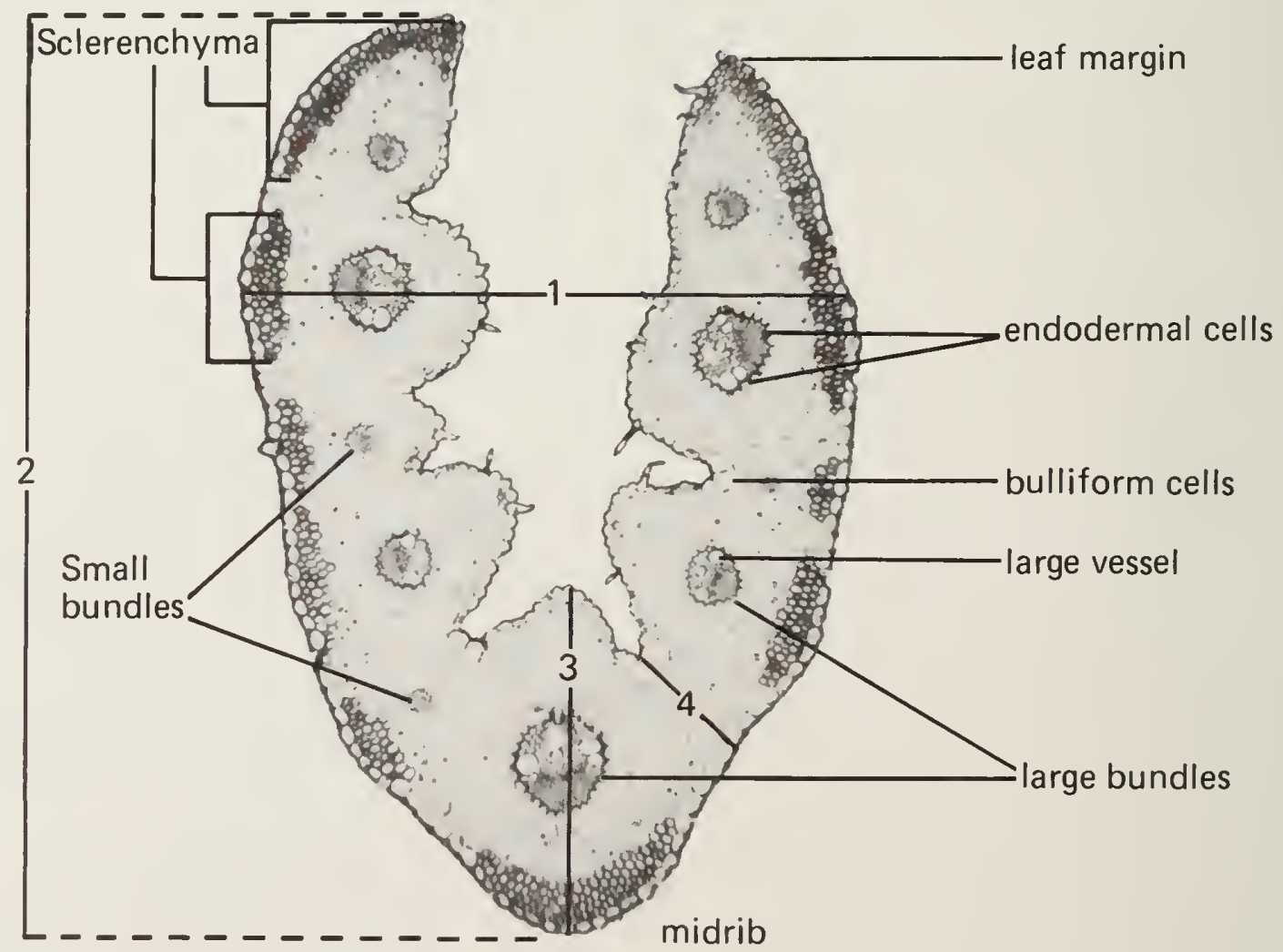

\section{Plate 3 Leaf cross section.}

Festuca idahoensis showing measurements of the width (1) at the widest point of the cross section and the distance ( 2 ) between the midrib abaxial epidernis and the most distant epidermal cell; vascular bundles; sclerenchyma; five well-defined ribs (about $100 \times$ ). 

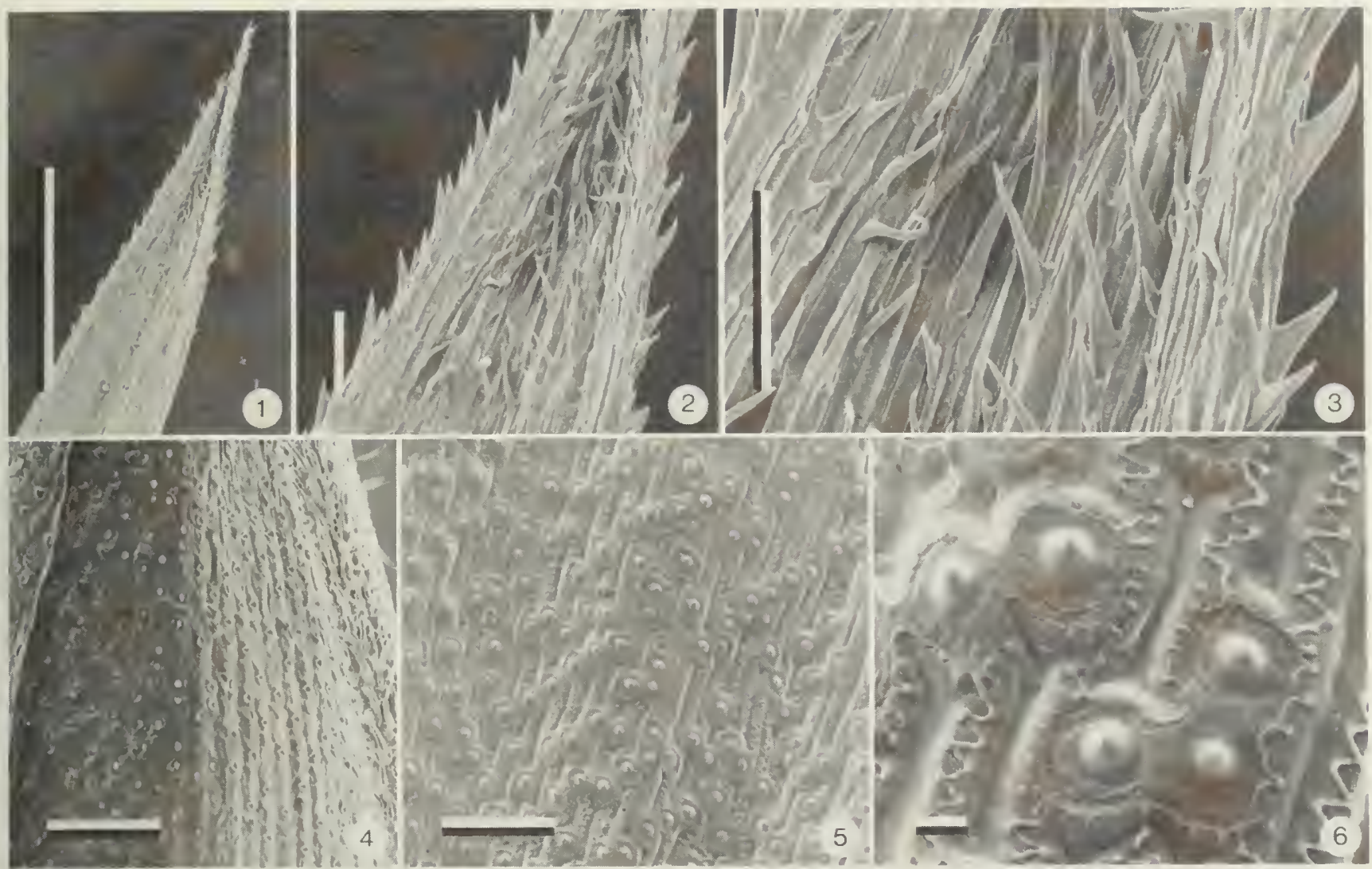

\section{Plate 4 Palea vestiture.}

(1-3) Festuca baffinensis showing a palea distinctly hairy between the veins (1, bar = $1 \mathrm{~mm} ; 2,3$, bar $=0.1 \mathrm{~mm}$ ).

(4-6) Festuca subverticillata showing a palea that is not distinctly hairy between the veins $(4,5$, bar $=0.1 \mathrm{~mm} ; 6$, bar $=0.01 \mathrm{~mm}$ ).

(Plate 5, Fig. 5) to open the floret by separating the lemma and palea. The upper half of the lodicule is thinly membranous and is usually divided into two or more teeth (Plate 5, Fig. 5). The presence of trichomes on the lodicule margins in species that also have hairs at the ovary apex is variable. Species lacking hairs on the ovary usually have glabrous lodicules. Lodicule characters are not significant at the species level. The stamen position relative to the palea length is related to the overall length of the mature anthers. It can be useful in separating small plants of $F$. saximontana and $F$. idahoensis. It was found impractical to distinguish "anthers lying at about half the length of paleas" (Appendix). The presence of hairs on the ovary a pex is an extremely useful and reliable character (Plate 5, Figs. 1-5), although it can be quantitatively variable (compare Plate 5, Figs. 3 and 5). Hairs are usually easily seen even on the mature caryopsis. Hairs develop after the styles have separated on the developing ovary and the character is totally reliable on ovaries from florets just prior to anthesis and older. This character is particularly useful in distinguishing $F$.occidentalis from $F$. idahoensis and $F$. rubra, or $F$. viridula from $F$. rubra, or $F$. minutiflora from $F$. brachyphylla, and even $F$. baffinensis from $F$. brachyphylla.

\section{DELTA}

The computer data base for this project was developed for use with the DELTA system. Although an excellent way to gather, organize, and store data, various difficulties encouraged the generation of key and species description by classical means. 

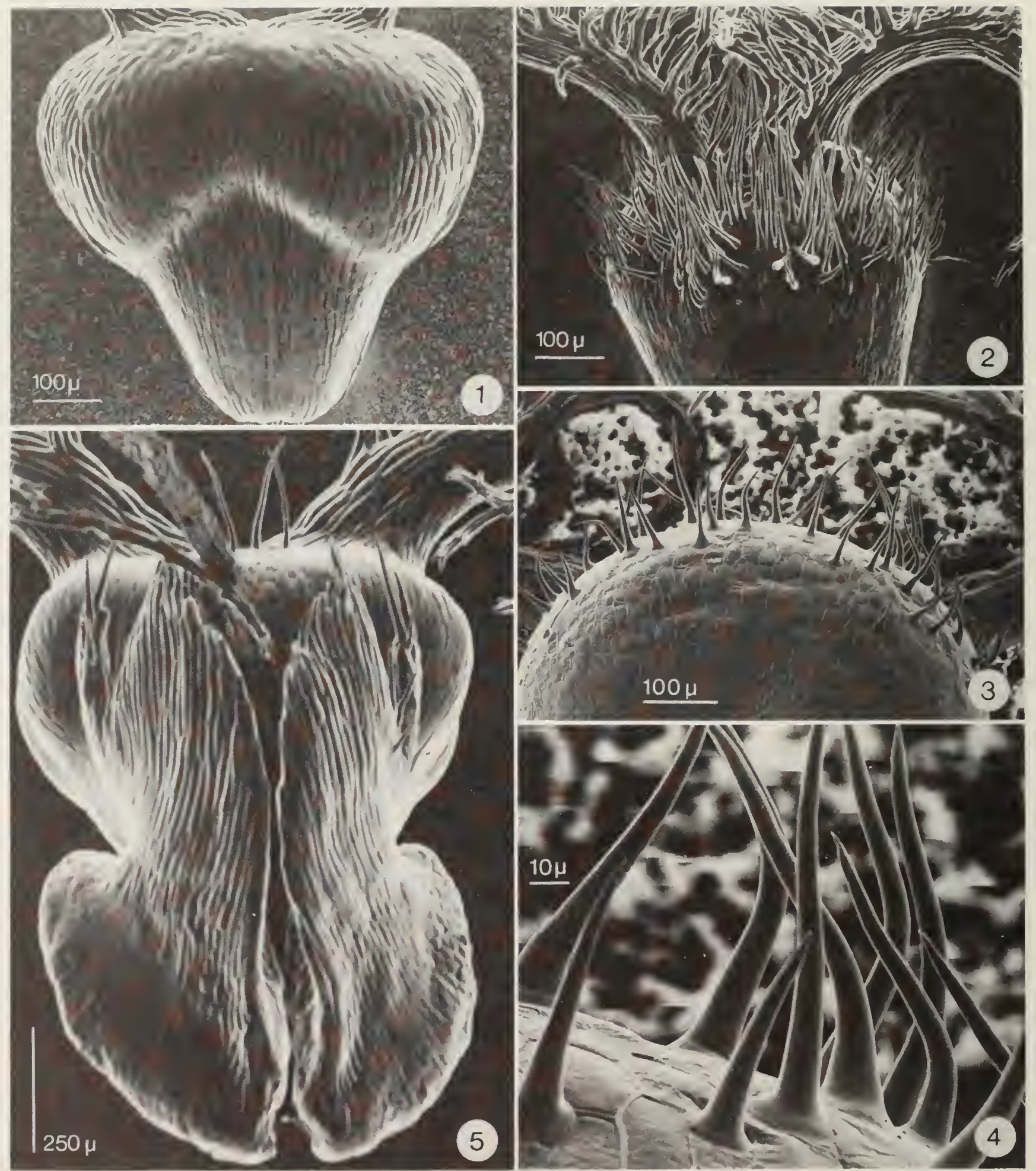

5

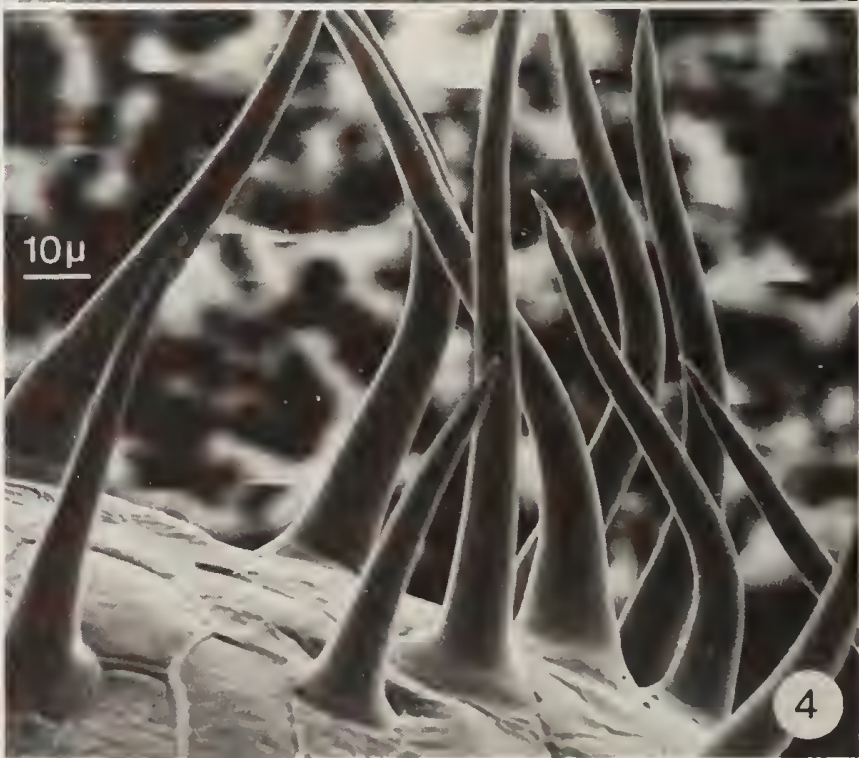

Plate 5 Ovary and lodicule characteristics.

(1) Festuca saximontana showing a glabrous ovary.

(2) Festuca occidentalis showing a densely pubescent ovary apex.

(3-5) Festuca altaica: $(3,4)$ Ovary showing a sparely hairy apex. (5) Showing two toothed lodicules with marginal trichomes in front of an ovary with only three hairs at the apex. 


\title{
Generic description
}

\author{
Festuca L., Sp. Pl.:73. 1753. \\ Type: F. ovina L.
}

Perennials, densely caespitose or rhizomatous. Culms herbaceous, unbranched, usually glabrous, $2-150(-200) \mathrm{cm}$ high. New shoots extravaginal or intravaginal. Leaves basally aggregated or both basal and cauline. Leaf sheaths closed or open. Auricles absent, erect, or clawlike. Ligule usually very short, $0.1-1(-2.5) \mathrm{mm}$ long (rarely to $6.5 \mathrm{~mm}$ long in species occurring outside Canada), often erose, ciliate, and higher on the sides than in the centre. Leaf blades flat or setaceous, folded or rolled in bud, to $1.5 \mathrm{~cm}$ wide, with adaxial surface usually pubescent to lightly scabrous and abaxial surface glabrous to pubescent.

Abaxial leaf-blade epidermis lacking microhairs; mid-intercostal long cells usually markedly sinuous, with or without crescentshaped silica bodies; intercostal short cells common; stomates absent or rare; guard cells overlapped by interstomatal cells. Leaf blade anatomy in cross section with $\mathrm{C}_{3}$ anatomy; mesophyll with nonradiate chlorenchyma; vascular bundles with or without adaxial to abaxial sclerenchyma girders; with or without distinct ribs; bulliform cells occurring in simple fan-shaped groups; abaxial sclerenchyma in strands varying from very slender at midrib and margins, to slender or wide opposite main vascular bundles, to well-developed and even continuous under epidermis.

Plants bisexual with hermaphroditic florets (dioecious species known from the United States and central Asia; also, many species with spikelets occasionally undergoing vegetative proliferation). Inflorescence an open or contracted panicle, sometimes with capillary branchlets, rarely a raceme. Spikelets
3-25 mm long, laterally compressed, disarticulating above glumes and between the (rarely 1-)2-10(-25) florets, with adjacent rachilla internode remaining attached (i.e., diaspores composed of a single phytomere). Rachilla usually pubescent or scabrous, prolonged apically beyond terminal fertile floret (with or without vestigial florets). Glumes 2, relatively large, acute, unequal, or rarely subequal, usually shorter than adjacent lemmas; lower glumes 1(-3)-veined, sometimes keeled; upper glumes (1-)3-5-veined, often rounded on the back. Callus glabrous (in all Canadian species except $F$. subuliflora).

Lemmas usually similar in texture to glumes, coriaceous-herbaceous, 2.5-9 $\mathrm{mm}$ long, rounded or slightly folded basally, sometimes keeled toward apex, with or without trichomes; veins 3-5, more or less prominent; either awnless or with a single straight or crinkled 0.2-20-mm awn that arises dorsally (or rarely subapically) from an acute apex. Palea 2-keeled, about as long as the lemma, enclosing but not adhering to caryopsis, with or without conspicuous trichomes between keels; keels usually with at least a few hairs apically. Lodicules 2, distally membranous, with toothed margins, with or without trichomes. Stamens 3 , anthers $0.4-3(-5) \mathrm{mm}$ long. Ovary apex glabrous or hairy; styles free to their bases; stigmas white. Caryopsis 2-5 mm long; hilium linear; endosperm hard, with compound starch grains. Embryo small, with an epiblast and without a scutellar tail; embryonic leaf margins meet.

$x=7$. 


\section{Key to species}

1 Leaves broad, flat to loosely rolled, $>2 \mathrm{~mm}$ wide, with sclerenchyma either at both abaxial and adaxial surfaces opposite major veins or forming a continuous adaxial to abaxial band (girder) at major veins .........................

1 Leaves narrow, tightly folded or rolled, rarely flat, $<2(-2.5) \mathrm{mm}$ wide, with sclerenchyma on abaxial side only (rarely with small bundles at adaxial surface in $F$. rubra) not touching major veins

2

Plants more or less densely caespitose (sometimes with short rhizomes), usually $>30 \mathrm{~cm}$ high. Tillers and culms erect; culm nodes usually not visible. Dead leaf sheaths persistent from year to year. Leaf blades abaxially scabrous, adaxially scabrous to hirsute, rolled or rarely flat, (1-)2-3(-4) $\mathrm{mm}$ wide. Auricles lacking. Lemmas short-awned to awnless

Plants loosely or densely caespitose, usually $<30 \mathrm{~cm}$ high. Tillers often decumbent or curved, culms often slightly curved at base; some culm nodes usually visible. Dead leaf sheaths usually not persistent from year to year. Leaf blades abaxially glabrous to scabrous, adaxially glabrous to pilose, usually flat, 2-18 $\mathrm{mm}$ wide. Auricles absent or clawlike. Lemmas long-awned to awnless

Foliage yellow green to dark green; leaf blades in cross section with sclerenchyma only opposite veins. Panicle drooping (when mature), with branches flexuous and lax. Upper glume distinctly shorter than adjacent lemma. Lemmas laterally folded basally, usually red or purple with anthocyanin; lateral nerves more or less prominent. Plants of boreal and alpine grasslands

F. altaica

Foliage light green to gray green; leaf blades in cross section with sclerenchyma extending along abaxial side between veins. Panicle not drooping, with branches stiff, erect, or slightly spreading. Upper glume somewhat shorter than, to as long as, adjacent lemma. Lemmas dorsally rounded basally, usually green or stramineus; lateral nerves obscure. Plants of plains and montane grasslands

4 Plants strongly caespitose; shoots intravaginal

Culms (30-)40-90(-140) cm high. Spikelets with (3-)4-5(-7) florets, distinctly longer than glumes. Upper glume somewhat shorter than adjacent lemma. Lemmas (6-)7-8.5(-10) mm long. Plants of foothills and montane grasslands in western Alberta and British Columbia F. campestris 
Plants caespitose; shoots intravaginal and extravaginal forming creeping rhizomes. Culms (18-)20$65(-85) \mathrm{cm}$ high. Spikelets with 2-3(-4) florets (3rd (and 4th) usually sterile), scarcely if at all longer than glumes. Upper glume about equal to adjacent lemma. Lemmas 5.5-7(-9) mm long. Plants of western plains and parklands from western Ontario to Alberta F. hallii

Lemmas either awnless or with awn much shorter than lemma body

Leaf blades 6-18 mm wide, coarse. Auricles clawlike. Ovary apex glabrous. Plants introduced as ornamentals at isolated sites in southern Quebec ......... F. gigantea

Leaf blades 2-10 mm wide, lax. Auricles lacking. Ovary apex with hairs. Native plants of forests in southern British Columbia and extreme southwestern Alberta .... 7

Leaf blades pubescent or glabrous, $2-4(-6) \mathrm{mm}$ wide. Ligule 0.1-0.5 mm long. Lemma callus long, acute, and pubescent with short stiff hairs at base; awn usually distinctly crinkled. Plants of dry forests in southwestern British Columbia ..... F. subuliflora Leaf blades glabrous, 3.5-10 mm wide. Ligule 0.2-1 mm long. Lemma callus short, obtuse, and glabrous; awn usually approximately straight. Plants throughout southern British Columbia and extreme southwestern Alberta ......... F. subulata

8 (5) Leaves without auricles. Panicles drooping, diffuse, with spikelets near ends of branches; lower branches usually reflexed; upper branches spreading. Lemmas broadly rounded dorsally, obtuse to broadly acute, 3.2-4.5 mm long, awnless. Anthers 1.1-1.6 mm long. Ovary apex with hairs. Plants of moist fields, swamps, and woodlands from southern Manitoba eastward F. subverticillata

Leaves with membranous spreading-to-clawlike auricles.

Panicles not drooping, spreading at anthesis but otherwise strict, more or less compact, with spikelets to base of branches. Lemmas rounded or folded dorsally, acute, 4-9(-10) $\mathrm{mm}$ long, awnless or short-awned. Anthers (1.5-)2-4.5 mm long. Ovary apex without hairs. Introduced plants cultivated and adventive in open habitats throughout southern Canada

Old sheaths pale straw-colored, often remaining intact. Leaf blades 3-12 mm wide, coarse with many silica bodies; veins prominent on adaxial surface. Auricles ciliate, sometimes only with a single cilium (check several auricles at magnification of $10-20 \times$ ). Lowest panicle node with $2-3$ branches; all branches 
with $>1$ (usually $>4$ ) spikelet(s). Spikelets elliptic to oblong, with 3-6(-9) florets. Lemmas usually scabrous apically; awns about $0.3-2(-4) \mathrm{mm}$ long, rarely absent .......... $F$. arundinacea

Old sheaths brown, decaying to fibers. Leaf blades 3-6(-7) mm wide, lax with few silica bodies; veins not prominent on adaxial surface. Auricles lacking cilia. Lowest panicle node usually with 2 branches; 1 branch with only $1(-3)$ spikelet(s). Spikelets cylindric to oblong, with (2-)4-10(-12) florets. Lemmas apically glabrous; aristate or lacking awns ................ Fratensis

10 (1) Lemmas awnless, some with a mucro less than one-tenth length of lemma body .............................. 11

Lemmas awned; awn often absent in proliferating forms, some poorly developed but more than one-tenth length of lemma body

11 Plants $35-80 \mathrm{~cm}$ high. Leaf blades $0.8-2.5 \mathrm{~mm}$ wide, with $7(-9)$ veins in cross section. Lemmas $4.8-8.5 \mathrm{~mm}$ long. Anthers (2.0-) 2.5-5 mm long. Ovary apex with hairs. Native plants of subalpine meadows in southcentral British Columbia ... F. viridula

11 Plants (5-)10-40(-55) $\mathrm{cm}$ high. Leaf blades to $1.5(-1.8) \mathrm{mm}$ wide, with $3-5$ veins in cross section. Lemmas $<4.5 \mathrm{~mm}$ long. Anthers (when present) $1.2-2.2 \mathrm{~mm}$ long. Ovary apex without hairs. Plants widespread in Canada

12 Leaf blades filiform, $<1 \mathrm{~mm}$ wide; sclerenchyma in cross section in a continuous or almost continuous band. Spikelets not proliferating. Lemmas 2.3-4.0(-4.4) $\mathrm{mm}$ long. Plants introduced and adventive in disturbed areas in southern Canada ................. F. filiformis

12 Leaf blades about 1-1.8 mm wide; sclerenchyma in cross section in a continuous band or greatly reduced. Spikelets proliferating. Lemmas, at least some, becoming leaflike. Plants native to arctic, subarctic, and alpine tundras and rocky places $\ldots \ldots \ldots \ldots, F$. vivipara

13 (10) Shoots intravaginal and extravaginal; extravaginal shoots forming slender rhizomes. Leaf sheaths closed to near the mouth; old sheaths brown and decaying to fibers. Anthers 2.0-3.0(-4.0) $\mathrm{mm}$ long

13 Shoots intravaginal only, without rhizomes. Leaf sheaths open or closed up to three-quarters of their length; old sheaths strawcolored or brown, decaying to fibers or not. Anthers various

14 Lemmas densely pubescent. Plants of arctic and subarctic habitats ...................... F. richardsonii

14 Lemmas glabrous to scabrous. Plants of subarctic and

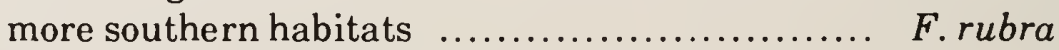

15 (13) Lower branches of panicle usually spreading or reflexed at maturity, sometimes erect; pedicels about as long as or longer 
than spikelets. Lemma bodies usually >(4.5-) $5 \mathrm{~mm}$ long; lemma awns $>2.5 \mathrm{~mm}$, half as long as to longer than lemma body ....... 16

15 (13) Lower branches of panicle usually spreading or reflexed at maturity, sometimes erect; pedicels about as long as or longer than spikelets. Lemma bodies usually $>(4.5-) 5 \mathrm{~mm}$ long; lemma awns $>2.5 \mathrm{~mm}$, half as long as to longer than lemma body

15 Lower branches of panicle erect or spreading only at anthesis; pedicels mostly distinctly shorter than spikelets. Lemma bodies usually $<5 \mathrm{~mm}$ long; lemma awns $<2.5(-3) \mathrm{mm}$ long, distinctly shorter than and usually less than half as long as lemma body .... 17

Plants loosely caespitose. Dead sheaths not persistent, decaying to fibers. Foliage smooth and flexuous, with scattered silica bodies within epidermis. Lower branches of panicle reflexed at maturity. Lemmas $4.5-6.5 \mathrm{~mm}$ long; awns (3-)4.5-8(-12) $\mathrm{mm}$ long. Anthers $<2.0 \mathrm{~mm}$ long; ovary apex with hairs ............. $F$. occidentalis

Plants densely caespitose. Dead sheaths persistent, not decaying into fibers. Foliage rough, with extensive silica deposits forming abaxial prickles. Lower branches of panicle erect to distinctly spreading, not reflexed. Lemmas 5-8 mm long; awns (1.5-)3-6(-7) mm long. Anthers $>2.0 \mathrm{~mm}$ long; ovary apex without hairs

F. idahoensis

17 (15) Culms hirsute to densely pubescent below inflorescence, with short stiff curved antrorse hairs. Branches of inflorescence more or less secund, commonly arched to one side of rachis. Lemmas 4-6 mm long. Ovary apex with few hairs. Anthers 0.2-0.7 (-1.1) $\mathrm{mm}$ long F. baffinensis

17 Culms glabrous to scabrous or sparcely pubescent below inflorescence. Branches of inflorescence not secund, with spikelets on all sides of rachis. Ovary apex without hairs (or if with a few trichomes then lemmas 2.2-3.4(-4.0) $\mathrm{mm}$ long). Anthers usually $>0.7 \mathrm{~mm}$ long

18 Leaf sheaths open to the base; old sheaths strawcolored to light brown, not splitting into fibers. Leaf blades 0.5-1.2 $\mathrm{mm}$ wide, in cross section ribbed, with 3-5(-9) commonly confluent sclerenchyma bundles. Lemmas 3.8-5 mm long. Anthers 2.5-3 mm long F. trachyphylla

18 Leaf sheaths variously closed; old sheaths strawcolored to brown, remaining entire or splitting into fibers. Leaf blades $0.3-0.5 \mathrm{~mm}$ wide, in cross section ribbed or not, with sclerenchyma various. Lemmas various. Anthers usually $<2.5 \mathrm{~mm}$ long (sometimes longer in $F$. lenensis) 

above foliage tuft. Anthers (0.8-)1.2-2.5(-3) mm long .......... 20

19 Panicles long exserted from sheath of flag leaf or not; inflorescence well above foliage tuft or not. Anthers $<1.1(-1.3) \mathrm{mm}$ long $\ldots . .23$

20 Usually at least some leaf blades obviously abaxially hirsute to pubescent (examine all available blades and sheaths at $10 \times)$, in cross section with sclerenchyma in 3 bundles (at the midvein and margins). Lower branches of panicle usually 1 per node, with only $1(-3)$ spikelet(s). Anthers 2-2.5(-3) $\mathrm{mm}$ long. Beringean plants from mainly alpine tundras in the Yukon and Northwest Territories F. lenensis

Leaf blades never obviously abaxially hirsute or pubescent (sometimes minutely scabrous), in cross section with sclerenchyma in 3-5 or more bundles to continuous. Lower panicle branches 1 or usually more per node, with 1 or usually more than 1 spikelet.

Anthers (0.8-)1.2-1.6 mm long. Plants throughout much of Canada

21 Plants usually $>30 \mathrm{~cm}$ high. Sclerenchyma in cross section of leaf blades either in bands $2 \times$ as wide as deep, or more or less confluent, to a continuous subepidermal band. Panicle usually $>5 \mathrm{~cm}$ long. Anthers (1.0-) 1.2-1.6 mm long ....... F. saximontana

21 Plants usually $<20(-30) \mathrm{cm}$ high. Sclerenchyma in cross section of leaf blades in $3-5(-7)$ discrete bundles $<2 \times$ as wide as deep, opposite major veins and at margins. Panicles usually more or less $3 \mathrm{~cm}$ long. Anthers $0.8-1.0(-1.3) \mathrm{mm}$ long $\ldots \ldots \ldots \ldots \ldots \ldots 22$

22 Blades of flag leaf usually $>1 \mathrm{~cm}$ long; sheaths of flag leaf scarcely or not at all inflated ........ F. brachyphylla

Blades of flag leaf absent or short (usually $\pm 2 \mathrm{~mm}$ long, although sometimes longer); sheaths of flag leaf distinctly or at least slightly inflated

23 (19) Foliage fine and setaceous. Panicles long exserted from sheath of flag leaf; lower branches of panicle with more than 1 spikelet. Lemmas 2.2-3.4(-4.0) $\mathrm{mm}$ long. Ovary apex with a few hairs. Cordilleran plants of alpine habitats in British Columbia and the Yukon F. minutiflora

23 Foliage various. Panicles long exserted from sheath of flag leaf or not completely exserted; lower branches of panicle with 1 or more spikelets. Lemmas (3-)4-6(-7) mm long. Ovary apex without hairs. Beringean or holarctic species of boreal to high arctic and alpine (including cordilleran) habitats

24 Panicle usually with more than 8 spikelets; lower

$(22,23)$ branches of panicle with more than 1 spikelet. Sheaths of flag leaf scarcely or not at all inflated; blade of flag leaf $>1 \mathrm{~cm}$ long F. brachyphylla 
24 Panicles usually with fewer than 8 spikelets; lower branches of panicle usually with only 1 spikelet.

Sheaths of flag leaf slightly to distinctly inflated;

blades of flag leaf occasionally absent or usually

$<1 \mathrm{~cm}$ long

25 Plants loosely tufted; culms often geniculate or semiprostrate.

Dead leaf sheaths not forming persistent tufts. Leaves often glaucous; basal leaves curved and tapering rapidly at the tip.

Culms up to twice as long as foliage tuft. Inflorescence long, exserted from sheath of flag leaf or partially enclosed; branches of panicle erect at anthesis. Upper glumes acute to obtuse. Lemmas ovate to lanceolate; awn short, often slightly bent, curved or sinuate. Holarctic plants of subarctic and arctic tundras F. hyperborea

25 Plants densely tufted; culms erect. Persistent dead leaf sheaths in tufts. Leaves not glaucous; basal leaves more or less straight and long tapering. Culms usually more than twice as long as foliage tuft. Inflorescence usually long exserted from sheath of flag leaf; branches of panicle spreading at anthesis. Both glumes long, acuminate. Lemmas lanceolate; awn erect or straight. Beringean plants of alpine tundras in the Yukon F. brevissima 


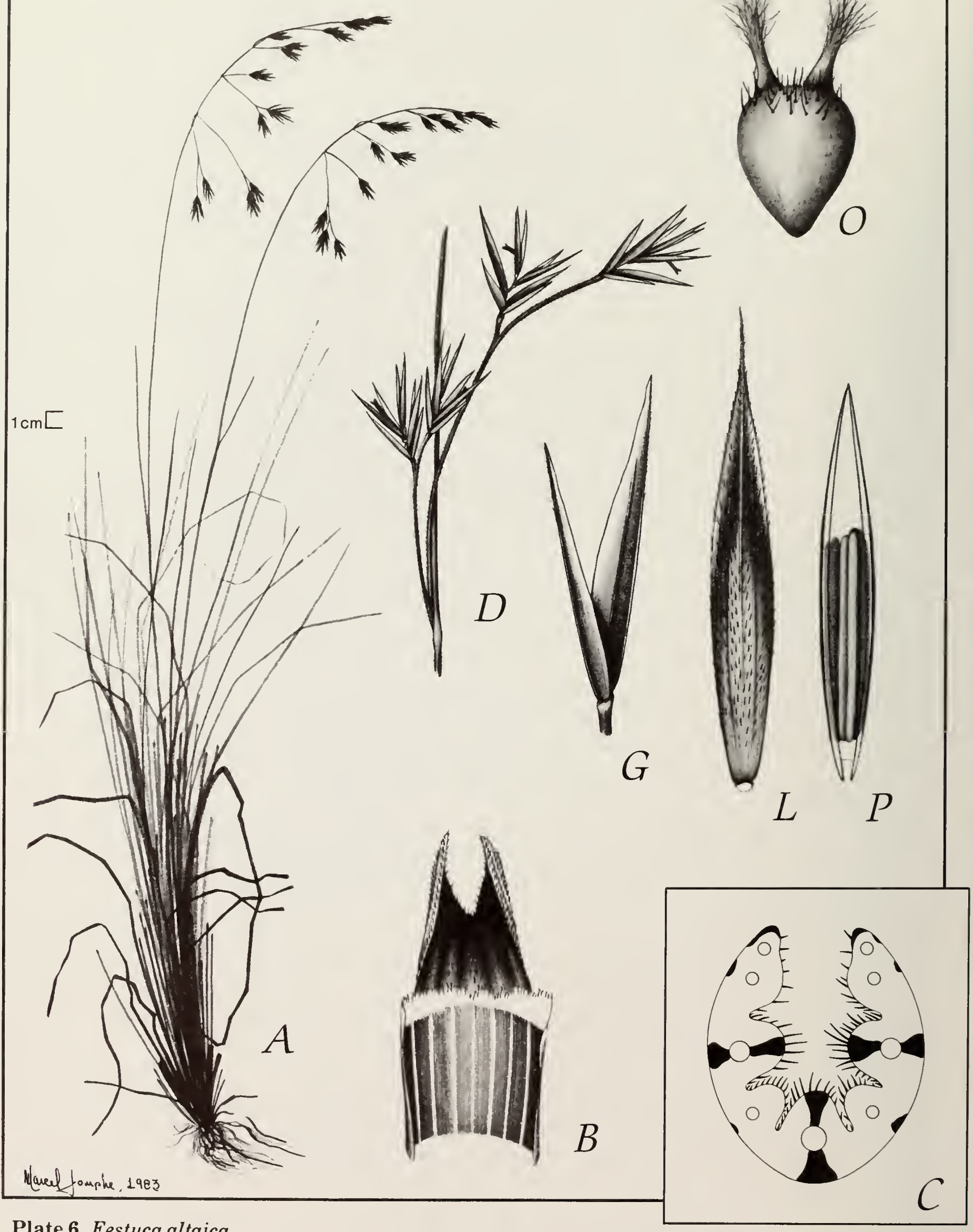

Plate 6 Festuca altaica. 


\section{Festuca altaica}

Festuca altaica Trinius in Ledebour, Fl. Alt. 1:109. 1829

F. scabrella Torrey in Hooker, Fl. Bor.-Amer. 2:252. 1840.

\section{Northern rough fescue \\ Plate 6, Map 1}

Plants yellowish green or dark green, densely caespitose, with short inconspicuous rhizomes between tillers in bunches. Culms (25-)30-90 $(-120) \mathrm{cm}$ high; nodes never exposed; culm internodes glabrous to scabrous. Dead blades breaking off at collars leaving entire sheaths that persist for many years. Shoots intravaginal and sometimes extravaginal. Living sheaths with or without purple pigments, open, glabrous to scabrous, rounded with a prominent midvein. Auricle positions with or without a distinct swelling. Ligule distinctly erose, $0.2-0.6$ (-1) $\mathrm{mm}$ long. Blades (5-)10-30(-35) $\mathrm{cm}$ long, stiffish, plicate or flat, 1-3(-4) $\mathrm{mm}$ wide; blade of flag leaf (2-)3-5(-8) cm long. Blade anatomy in cross section $3-5(-7)$ large and $4-10$ small veins; ribs $6-8$; sclerenchyma adaxial to abaxial girders present and abaxial opposite vascular bundles.

Panicle 5-16 cm long; branches flexuous; lowest branches (1-)2 at node; longer branches pulvinate, to $10 \mathrm{~cm}$ long, often all blown to one side of inflorescence; rachis branches rounded or angular, glabrous or scabrous. Spikelets purplish (rarely pale green, forma pallida Jordal), 8-14 mm long, with 3-4(-6) florets. Glumes much shorter than spikelets, unequal or subequal, usually keeled, scabrous; marginal zone transparent giving a sheen to the inflorescences; margins entire or erose; lower glume with 1 vein, (4-)4.2-6.8 mm long; upper glume with 1-3 veins, (4.5-)5.3-7.5(-10) $\mathrm{mm}$ long. Lemma rounded, (6.5-)7.5-9(-12) mm long, scabrous over the entire surface, with prominent veins; awn $0.2-0.7 \mathrm{~mm}$ long. Palea scaberulous between keels. Lodicules with one or more marginal teeth, occasionally with trichomes. Anthers 2.6-4.5 mm long, with top of anther lying about halfway along palea. Ovary apex pubescent, usually with fewer than 20 trichomes.
$2 n=28$ (Bowden 1960, Johnson and Packer 1968, Mulligan and Porsild 1970).

Distribution outside Canada: Michigan, Alaska, Far East (USSR) through eastern Siberia, northern Mongolia to the Altai region of central Asia.

\section{Discussion}

The recognition of $F$. altaica as a distinct species is generally accepted, despite persisting debate about the status of taxa in the rough fescue complex (Alexeev 1982, 1985; Pavlick and Looman 1984; Harms 1985). Plants from Quebec and Newfoundland, considered by most North American workers to be $F$. altaica, have been placed (with $F$. campestris Rydberg) under $F$. hallii by Alexeev (1985). Plants that do not produce purple in the spikelets have been described as forma pallida Jordal.

Vegetatively proliferat-ing forms may be referred to as forma vivipara Jordal. Both these forms have been described from the Brooks Range in Alaska (Jordal 1952).

In eastern North America, where populations are quite localized, $F$. altaica occurs on sand plains (northcentral Quebec and Michigan), gravel outwashes (western Newfoundland and Gaspé), serpentine barrens (western Newfoundland, Gaspé, and southern Quebec), limestone plains (Ungava), and basaltic slopes (western Newfoundland). In western Canada $F$. altaica occurs in alpine and subalpine areas, in open forest or untreed areas, rocky slopes and plateaus, northern meadows and grasslands in British Columbia, Yukon, and Northwest Territories. In southeastern Yukon it occurs at all elevations in many types of habitats (Porsild 1951) from subalpine forest, through open meadows, to open pine forests. The dense, tufted habit of the rough fescues makes them resistant to moderate grazing and light fire. 


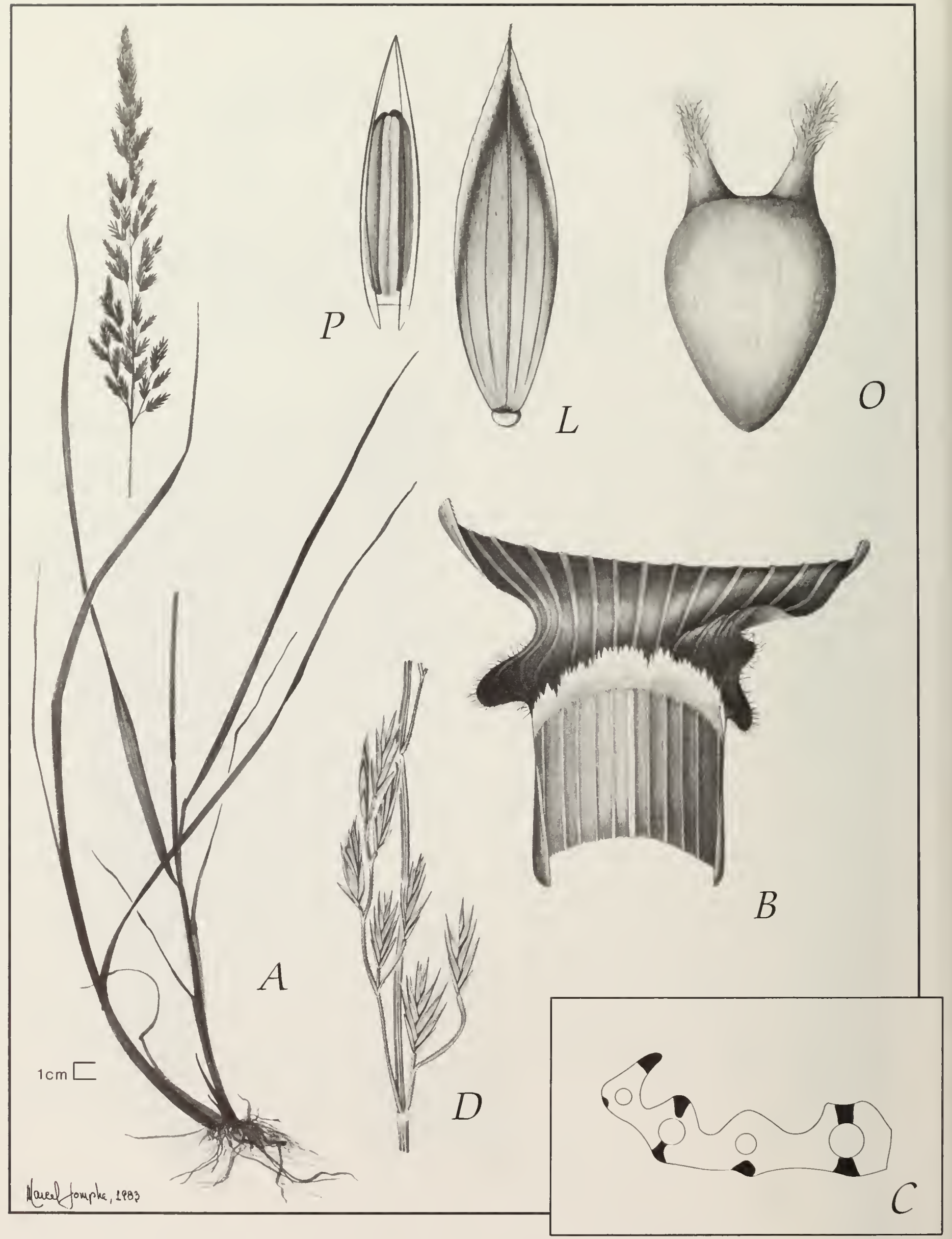

Plate 7 Festuca arundinacea. 


\title{
Festuca arundinacea
}

\author{
Festuca arundinacea Schreber, Spicil. Fl. Lips.:57. 1771 \\ F. elatior L., Sp. Pl.:75. 1753, nom. ambig. \\ Schedonorus elatior (L.) Beauvois, Ess. Agrost.:177. 1812. \\ F. elatior var. arundinacea (Schreber) Wimmer, Fl. Schles. ed. 3:59. 1857. \\ F. elatior ssp. arundinacea (Schreber) Čelakovský, Prodr. Fl. Bohm. 1:51. 1867
}

\section{Tall fescue, reed fescue \\ Plate 7, Map 2}

Plants caespitose (rhizomatous subspecies occur but have not been reported in Canada), dark green. Culms $60-150(-200) \mathrm{cm}$ high; nodes exposed, internodes glabrous. Dead sheaths, pale straw-colored, usually persistent. Shoots extravaginal. Living sheaths with or without purple pigments, open, rounded, glabrous or glabrescent. Auricles prominent, clawlike, with sparse or dense cilia. Ligules lacerate, erose, $0.4-1.5 \mathrm{~mm}$ long. Blades coarse, flat, rather rigid, $10-30(-40) \mathrm{cm}$ long, $3-12 \mathrm{~mm}$ wide; blade of flag leaf (8-) $10-23 \mathrm{~cm}$ long; adaxial epidermis glabrous; abaxial epidermis with short cork cells and long cells with undulating walls. Blade anatomy in cross section with adaxial to abaxial strands of sclerenchyma at most or all vascular bundles.

Panicle remaining loosely open or contracted after anthesis, $10-25(-35) \mathrm{cm}$ long; lowest node with 2-3 branches and with (3-)5-15 spikelets; longest branches of panicle $6-12 \mathrm{~cm}$, angular in cross section, with trichomes more prominently on the angles. Spikelets elliptic to oblong, 9-14 mm long, 3-6(-9) florets. Glumes much shorter than spikelets, unequal, rounded, glabrous or scaberulous at the apex only, margins membraneous; lower glumes $1-3$ veins, 3-7 mm long; upper glume 3(-5) veins, 4.5$8 \mathrm{~mm}$ long. Lemma rounded, glabrous or scabrous at the apex only, $5(-7)$ veins, 4-9 $(-10) \mathrm{mm}$ long, awn $0.3-1.5(-4) \mathrm{mm}$ long. Palea glabrous between the keels, $6-8 \mathrm{~mm}$ long. Lodicules elongate with marginal teeth, without trichomes. Anthers more than half the length of the palea, 3-4.5 mm long. Ovary apex glabrous.

$2 n=28,42,56,70$ (Taylor and Mulligan 1968, Borrill et al. 1971, Alexeev 1985).

Distribution outside Canada: Native through Europe, western USSR, Transcaucasia, Asia Minor to China, and North Africa. Introduced in many subtropical and temperate countries around the world.

\section{Discussion}

Festuca arundinacea is a valuable, coolseason forage grass that has been used for pasture and hay throughout eastern and southeastern North America since the last century. It has become a popular seeding for land stabilization. Several low-growing turf varieties have been developed recently for use in lawns and turf for sports facilities. The deep root system provides this grass with a greater tolerance to drought than other popular turf grasses. Like many wide-ranging species, tall fescue has distinguishable ecogeographic races (Robson 1967). These have been the basis for many studies, cytogenetic (e.g., Crowder 1953, 1956; Lewis 1963; Evans et al. 1973; Woodward and Frakes 1977; Berg et.al. 1979; Hunt and Sleper 1981), anatomical (Cohen et al. 1982a, b), and physiological (Lhamby 1978). It is not practical to ascribe subspecific names to the highly selected, anthropogenic forms present in Canada. Much of the research on tall fescue as an agronomically important plant was reviewed by Buckner and Bush (1979).

Terrell (1979) stated that the time of the introduction of tall fescue to the United States is unknown, but by 1870 seed catalogues were selling tall fescue labeled $F$. elatior as a "robust variety of meadow fescue [that] succeeds admirably in moist soils where the meadows are subject to flood." In Canada, $F$. arundinacea was collected for the first time at London, Ont., in 1878 and 1879 (Dore and McNeill 1980). These authors reported that in about 1950 tall fescue started to become popular in seedings for turf and meadows and in coarse mixtures for highway edges. Burns 
and Chamblee (1979) reported that, at

Saskatoon, winter kill occurred the first winter of seeding and at Brandon tall fescue persisted but was subject to considerable winter injury. They suggested that Brandon demarcates the northern limit of survival of tall fescue in North America. Several varieties have been tested in the Peace River District in Alberta with good winter hardiness and yields (Howe 1987). Ultimately winter coldness may be less of a restriction to its distribution than summer drought. The geographic and ecological range of tall fescue continues to expand through plantings and subsequent escape. In eastern Canada it is now commonly found as a ruderal weed and even as a lawn weed where prostrate growth may be induced in trampled and closely mown areas.

Usually it is easy to distinguish tall fescue from meadow fescue ( $F$. pratensis). Many essential details were given by Terrell (1979), although Boivin (1981) observed an overlap of morphological criteria and combined the two as varieties of $F$. elatior. Characters useful in distinguishing tall from meadow fescue include the presence of at least a few hairs (rarely glabrous) on the auricle margins (examine several auricles) and the pale straw-colored, intact leaf sheaths. Unfortunately auricles are commonly damaged or the basal leaf sheaths are missing on herbarium specimens. The leaves of tall fescue are wider and coarser than those of meadow fescue and form a more robust tuft. The foliage on tall fescue remains fresh well after the first frosts whereas the finer, more yellow-green foliage of meadow fescue, withers rapidly with the first frost. The coarse, stiff leaves of tall fescue have an abundance of silica bodies in the epidermal tissues (Huon 1965). Badoux (1971) showed that the abaxial leaf epidermis of $F$. arundinacea has cells with more or less undulating cell walls and cork cells in the intercostal zone, whereas $F$. pratensis has long cells with straight walls and no cork cells.

In Europe, naturally occurring sterile hybrids of intermediate morphology have been reported between $F$. arundinacea and $F$. pratensis $(F . \times$ aschersoniana), and Lolium perenne L. ( $\times$ Festulolium holmbergii). The close relationship between $F$ estuca subgenus Schedonorus and Lolium has also been demonstrated in the seed protein study of Butkute and Konarev (1982) and in the chloroplast DNA study of Lehväslaiho et al. (1987). The cytological and limited cpDNA data available suggest a closer relationship between this subgenus and Lolium than between it and subgenus Festuca. 



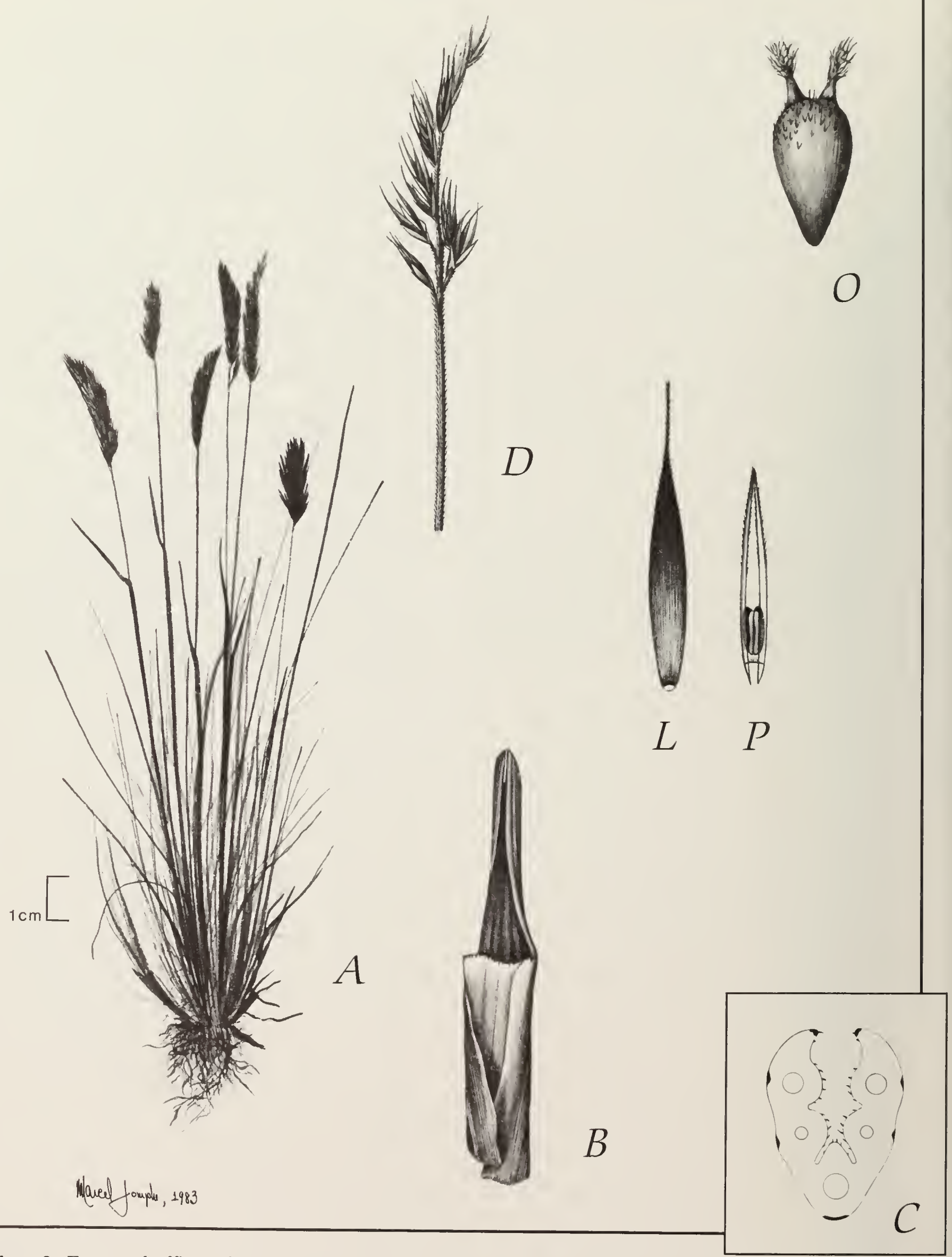

Plate 8 Festuca baffinensis. 


\section{Festuca baffinensis}

Festuca baffinensis Polunin, Natl. Mus. Can. Bull. 92. Biol. Ser. 24:91. 1940.

F. brevifolia var. arctica Saint-Yves subvar. pubiculmis Saint-Yves, Candollea 2:254. 1925.

\section{Plate 8, Map 3}

Plants caespitose, without rhizomes, green to bluish green. Culms $6-25(-30) \mathrm{cm}$ high, to twice the length of basal leaves but usually less, with or without exposed nodes; upper internode (at least the upper half) very densely tomentose with short curved hairs. Dead sheaths prominent, eventually decaying into fibers. Shoots intravaginal. Living sheaths with or without purple pigments, open for half their length; sheath of upper culm leaf slightly inflated, glabrescent. Auricle position with distinct erect swelling. Ligule $0.1-0.3 \mathrm{~mm}$ long, emarginate (obcordate) to truncate, erose Blades stiffish, setaceous, more or less pubescent, 1.5-10 cm long; blade of flag leaf (0.3-)0.7-2 cm long. Blade anatomy in cross section $0.25-0.6 \times 0.5-0.8 \mathrm{~mm}$; veins $3-7$; ribs $3-5$; sclerenchyma $3-7$ very slender strands.

Panicle somewhat secund, broadly ovoid, often very dense; branches ascending, $1.5-4 \mathrm{~cm}$ long; rachis branches angular in cross section $0.3-1.5 \mathrm{~cm}$ long, scabrous on and between angles. Spikelets usually purplish, $5-7.5$ $(-8.5) \mathrm{mm}$ long, with (2-)3-5(-6) florets. Glumes much shorter than spikelets, unequal, dorsally rounded, glabrous or scaberulous, with margins erose; lower glume 2.3-4 mm long, with 1 vein; upper glume $3-5 \mathrm{~mm}$ long, with 3 veins. Lemma rounded on the back, scaberulous towards the apex, elsewhere glabrous, glossy, 4-6 mm long; awn 0.8-2.6 (-3.3) $\mathrm{mm}$ long. Palea sparsely pubescent between the keels, 3.5-6 $\mathrm{mm}$ long. Lodicules with one or more marginal teeth, without trichomes. Anthers about one-third the length of palea, $0.3-0.7(-1.1) \mathrm{mm}$ long, subglobose to short cylindrical. Ovary apex with few trichomes.

$2 n=\mathbf{2 8}$ (Bowden 1960, Holmen 1964, Mosquin and Hayley 1966, Hedberg 1967).

Distribution outside Canada: Circumpolar, high arctic, and alpine species.

\section{Discussion}

Festuca baffinensis is easily recognized by the dense, somewhat secund inflorescence that is usually dark in color (brown-purple to almost black), by the dense, antrorsely curved pubescence on the upper part of the culm, and by its small, more or less subglobose anthers. In other Canadian arctic species culm pubescence is either absent, or, if present, is sparse and restricted to the very top of the culm. McNeill and Dore (1976) comparing $F$. baffinensis and $F$. brachyphylla stated "the customary diagnostic feature of culm hairiness does not correlate completely with other features such as ploidy level" and that within single spikelets of both $F$. baffinensis and $F$. brachyphylla anthers varying from 0.5-0.7 mm long can be found. Frederiksen (1977) observed a few specimens in which the culm is very sparsely hairy and suggested that these may form a transition between $F$. baffinensis and $F$. brachyphylla.

In the type description, Polunin (1940) stated, "in all my material of $F$. baffinensis stretching over its known range of more than $2,000 \mathrm{~km}$, the anthers are subglobose and still shorter (than $F$. brachyphylla), being only 0.3-0.5 mm long." Several collections from Arctic Canada that otherwise fit the $F$. baffinensis description have anthers more than $0.5 \mathrm{~mm}$ long (to $1.1 \mathrm{~mm}$ ).

Frederiksen (1977) in a paper on the $F$. brachyphylla group in Greenland, provided a table of 18 characters comparing $F$. baffinensis, $F$. brachyphylla, and $F$. hyperborea. Two of her characters, sheaths of the upper culm leaves inflated and spikelet length, help to confirm identification of $F$. baffinensis. The character "flag leaf blade normally exceeding $10 \mathrm{~mm}$ " is unreliable as most Canadian specimens have flag leaf blades 5-10 $\mathrm{mm}$ long. 

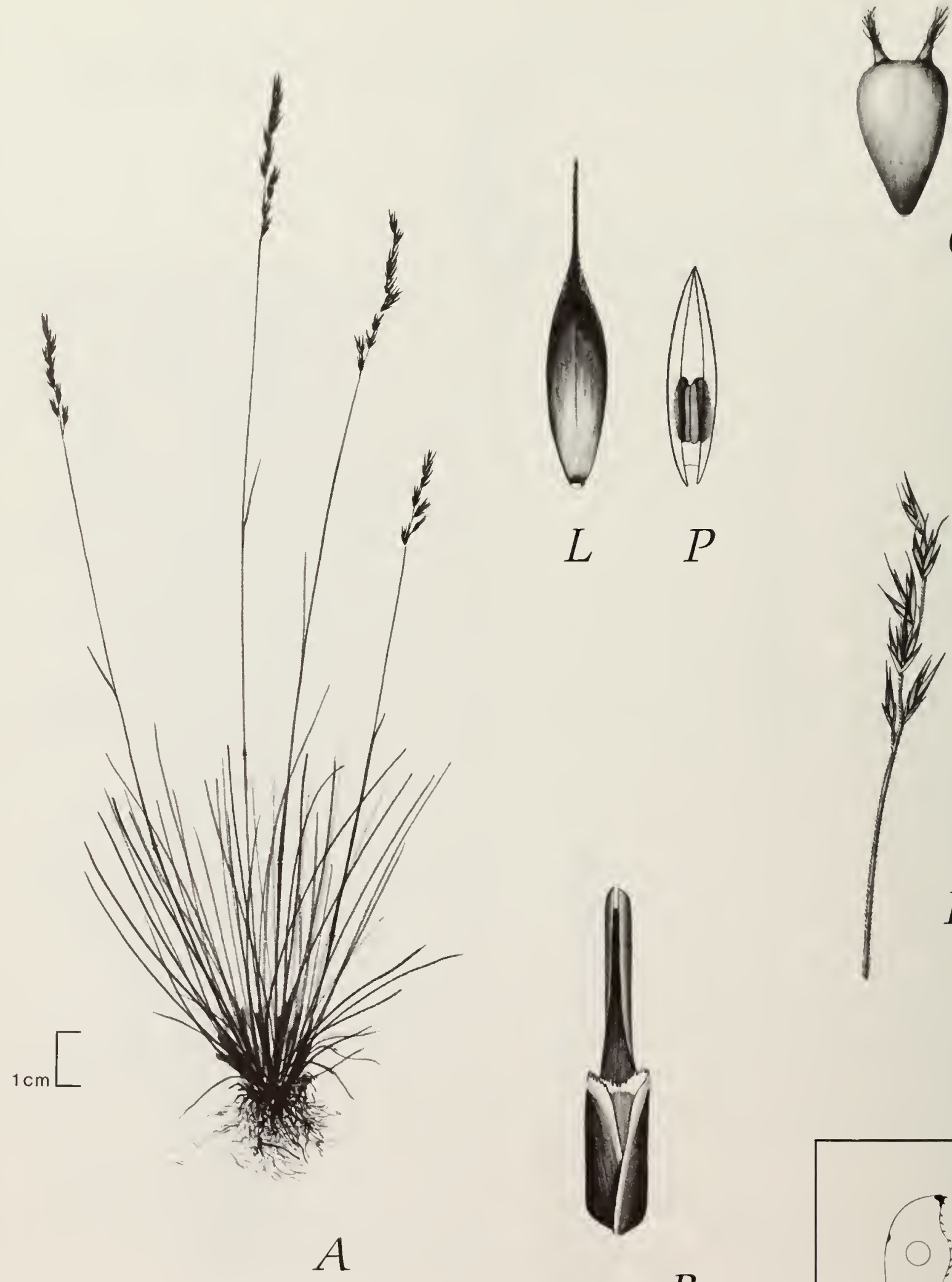

O

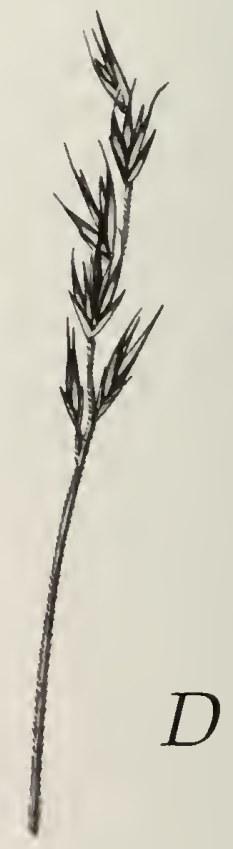

Naveelf fomptu, 2983

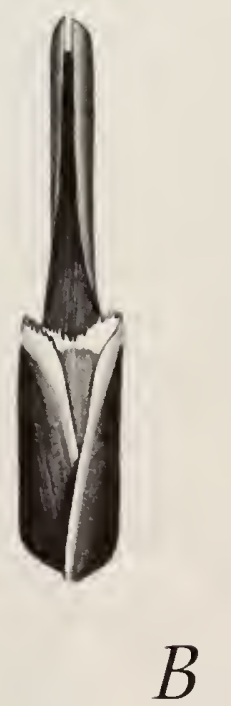

$D$

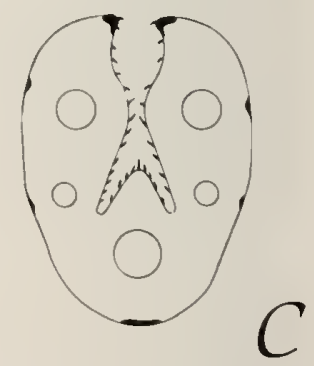

Plate 9 Festuca brachyphylla. 


\section{Festuca brachyphylla}

Festuca brachyphylla Schultes et Schultes fil., Add. ad Mantissa 3:646. 1827.

F. ovina var. brachyphylla (Schultes \& Schultes fil) Piper, Contrib. U.S. Natl. Herb. 10:27. 1906.

F. brevifolia R. Brown, Chloris Melvilliana:31. 1823, non Muhlenberg.

F.jenseni Gjaerevoll \& Ryvarden, Kongel. Norske Vidensk. Selsk. Skr. 4:18. 1977.

\section{Plate 9, Map 4}

Plants loosely to densely caespitose, bluish or fresh green. Culms (5-)8-30 cm high ( $-55 \mathrm{~cm}$ when cultivated), and with or without traces of purple at base with or without exposed nodes; internodes glabrous, or very rarely sparsely puberulent with stiff hairs. Shoots arising within or below existing tillers. Dead sheaths more or less prominent at base of plants, eventually splitting between veins; sheaths closed for at least half their length, glabrescent. Auricle positions usually with an erect swelling. Ligule minutely erose, $0.1-0.3 \mathrm{~mm}$ long. Blades stiffish, abaxially glabrous; blade of flag leaf $0.5-1.5 \mathrm{~cm}$ long. Blade anatomy in cross section $0.35-0.5 \times$ 0.3-0.7 $\mathrm{mm}$; veins 3 large, 2-4 small; ribs (1-) 3-5; sclerenchyma in 3-5 slender strands.

Panicle erect, spikelike, green or purple, 1.5-4(-5) cm long, with short erect branches; branches rarely to $1.2 \mathrm{~cm}$ long, with 1-4 spikelets, angular in cross section with trichomes on and between angles. Spikelets (3.5-)4.5-6(-7.3) mm long, sometimes glaucous, with 2-4(-6) florets. Glumes much shorter than spikelets, unequal, dorsally rounded, glabrous or scaberulous at the apex only, with margins erose; lower glume 1 vein, 1.8-3 $(-3.5) \mathrm{mm}$ long; upper glume 3 veins, 2.6-4(-4.5) $\mathrm{mm}$ long. Lemmas rounded on back, glabrous, or scaberulous at apex and margins only, (3-)3.7-5.5 mm long; awn 1.2-1.5(-3) $\mathrm{mm}$ long. Paleas $3-5.5 \mathrm{~mm}$ long, distinctly pubescent between keels. Lodicules toothed, without trichomes. Anthers (0.5-) $0.7-1.1(-1.3) \mathrm{mm}$ long, about one-third of palea length. Ovary apex glabrous.

$2 n=28,42,44$ (Bowden 1960, Mosquin and Hayley 1966, Hedberg 1967).
Distribution outside Canada: Circumpolar arctic and alpine species. Rocky Mountains south to New Mexico and California.

\section{Discussion}

Hultén (1942) observed that

F. brachyphylla is usually not very variable, although specimens from exposed places are very low-grown (like those from the Arctic Archipelago). He also commented that some specimens from southeastern Alaska are very "high-grown" and in general appearance resemble $F$. saximontana. A specimen of $F$. brachyphylla collected in the Yukon (Cody $\&$ Ginns 31632, DAO) had leaves $2-3 \mathrm{~cm}$ long, but after it was grown in the greenhouse for 6 months, the newly developed leaves were three times as long as the field collection.

The Festuca brachyphylla aggregate of species occurs throughout most arctic, subarctic, and alpine areas of the northern hemisphere with some forms adapted to warmer, xeric conditions (e.g., $F$. saximontana). A polyploid series is differentiated into a series of closely related species: $F$. brevissima $(2 n=$ $14), F$. baffinensis $(2 n=28), F$. minutiflora $(2 n=28), F$. hyperborea $(2 n=28,42)$, $F$. brachyphylla $(2 n=28,42), F$. saximontana $(2 n=42)$, and the polyphyletic $F$. vivipara ( $2 n=$ various multiples of seven). Frederiksen has published a table of distinguishing characters for Greenland species (Frederiksen 1977) and a key to North American species (Frederiksen 1982), which may be usefully consulted. (See also comments under $F$. hyperborea and $F$. saximontana.) 


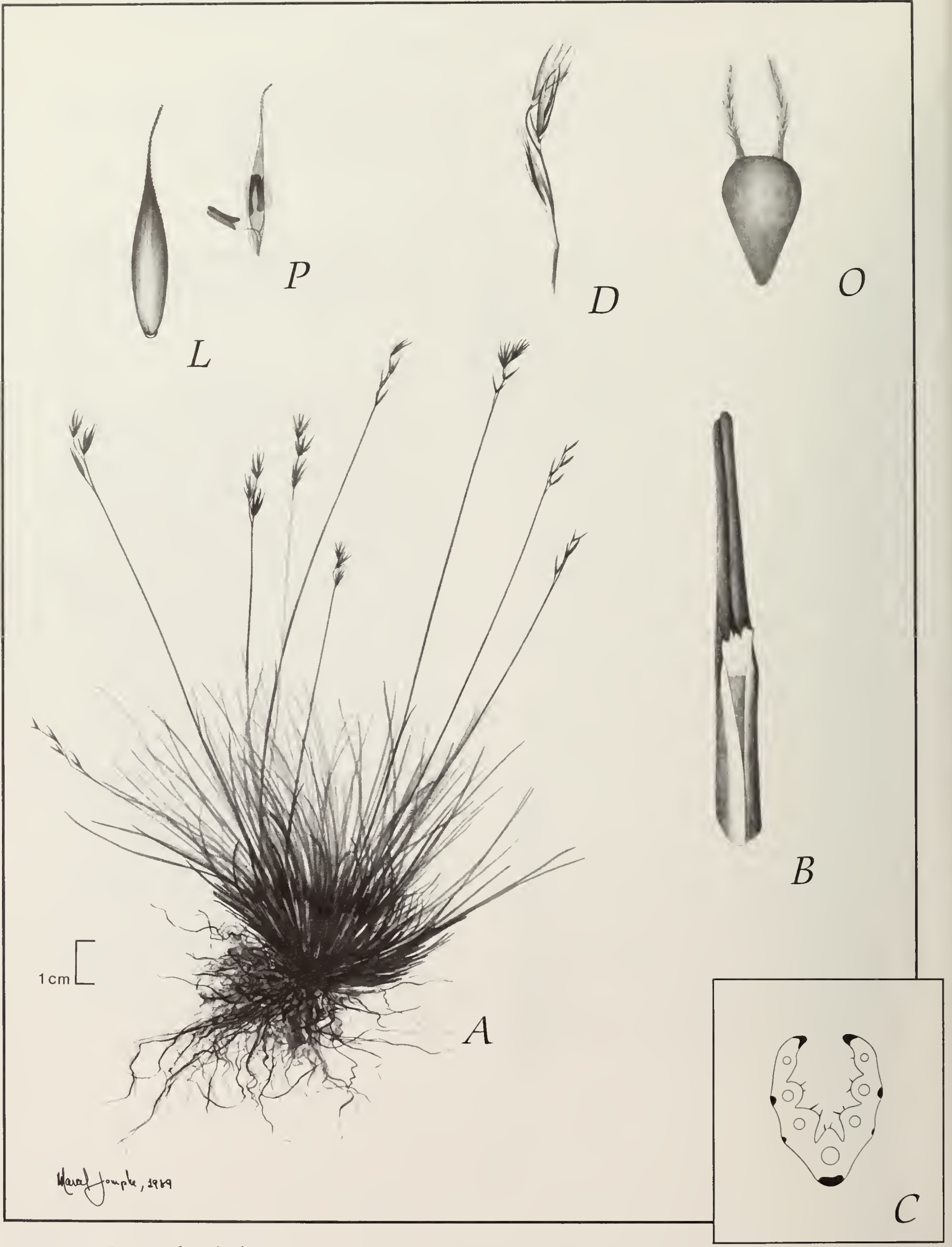

Plate 10 Festuca brevissima. 


\begin{abstract}
Festuca brevissima
Festuca brevissima Jurtzev, Bot. Zh. (Leningr.) 57:645. 1972.

F. ovina ssp. alaskana Holmen, Bot. Not. 117:115. 1964.
\end{abstract}

\title{
Plate 10, Map 5
}

Plants green to blue-green, caespitose, densely tufted, with groups of shoots surrounded at base by numerous dead leaf sheaths. Culms (2.5-)5.5-16(-18) cm high, erect, thin, and wiry; nodes rarely exposed; upper internodes glabrous, or scabrous $1-2 \mathrm{~cm}$ below panicle. New shoots intravaginal. Sheaths closed about one-half or more of their length, rounded, glabrous, prominent at the base of the plant; dead sheaths remaining entire; flag leaf sheath scarcely to slightly inflated. Auricle position with a distinct erect swelling. Ligule erose and ciliate, $0.3-0.5 \mathrm{~mm}$ long. Blade erect, stiffish, plicate, glabrous, or scabrous in lines along sclerenchyma strands. Blade anatomy in cross section $0.3-0.9 \times 0.5-$ $1.1(-2.5) \mathrm{mm}$; veins (3-)5-7; ribs pronounced (3-)5; sclerenchyma in 5-7 slender strands.

Panicle erect, 0.7-2.5(-5) cm long, often reduced to a raceme, with 3-14 spikelets; rachis thin and often slightly curved; branches rounded or angular in cross section, spreading at anthesis, with trichomes (when present) mainly on the ridges. Spikelets 4.5-6.1 $(-7) \mathrm{mm}$ long, with 2-4(-5) florets. Glumes unequal, usually acuminate, shorter than first lemma; lower glume with 1 vein, (1.2-)2.5$3.2 \mathrm{~mm}$ long; upper glume (1-)3 veins, (2.4-)3$4.8 \mathrm{~mm}$ long, glabrous, or slightly scabrous over most of outer surface; margins erose, ciliate. Lemma with trichomes on the upper portion, (3-)3.9-4.2(-7) mm long; a wn (0.2-)0.7-2.5 mm long. Palea glabrous between the keels, with conspicuous silica bodies, keels scabrous apically. Lodicules glabrous, with one or more marginal teeth. Anthers (0.6-)0.9-1.2 mm long, lying at about one-third to one-half of the length of paleas. Ovary apex glabrous.

$2 n=14$ (Holmen 1964 and Johnson and Packer 1968 in Alaska; Jurtzev and Zhukova 1978 in USSR).

Distribution outside Canada: Alaska and Far East (USSR).

\section{Discussion}

In Canada $F$. brevissima is found in alpine regions of west-central and northern Yukon. It grows on exposed, dry, rocky tundras. Frederiksen (1978) documented that the taxon previously known as $F$. ovina ssp. alaskana Holmen is conspecific with $F$. brevissima and mapped the distribution in Alaska. Material named as $F$. ovina ssp. alaskana by most North American authors is generally referable to $F$. lenensis. The anthers of $F$. ovina ssp. alaskana were originally described as being $2.5-3 \mathrm{~mm}$ long, as in $F$. lenensis, but the type specimen was determined by Frederiksen (1978) to have much shorter anthers and was referred to $F$. brevissima. (See also comments under $F$. lenensis.) Frederiksen (1982) provided the new combination of $F$. brevissima forma pallida (Holmen) Frederiksen to refer to plants with green or pale spikelets.

Unlike $F$. brachyphylla and $F$. hyperborea, $F$. brevissima has panicle branches spreading at anthesis. According to Frederiksen (1978) it further differs from $F$. brachyphylla in its smaller size, short blade of the culm leaf, fewer spikelets (usually one per branch), and glaucous color. It differs from $F$. hyperborea in its dense tufts, straight basal leaves, erect culms, somewhat longer anthers, and lanceolate lemmas with erect terminal awns. Other features assisting in the identification of $F$. brevissima include the thin, wiry rachis that is often slightly curved, the somewhat longer ligule, and the usually attenuate glumes.

As with most species in the $F$. brachyphylla aggregate, the low stature of $F$. brevissima and its occurrence in cold, treeless habitats means that it is of little importance as livestock forage. In their wide distribution and often local abundance, these species provide important forage for wildlife. 


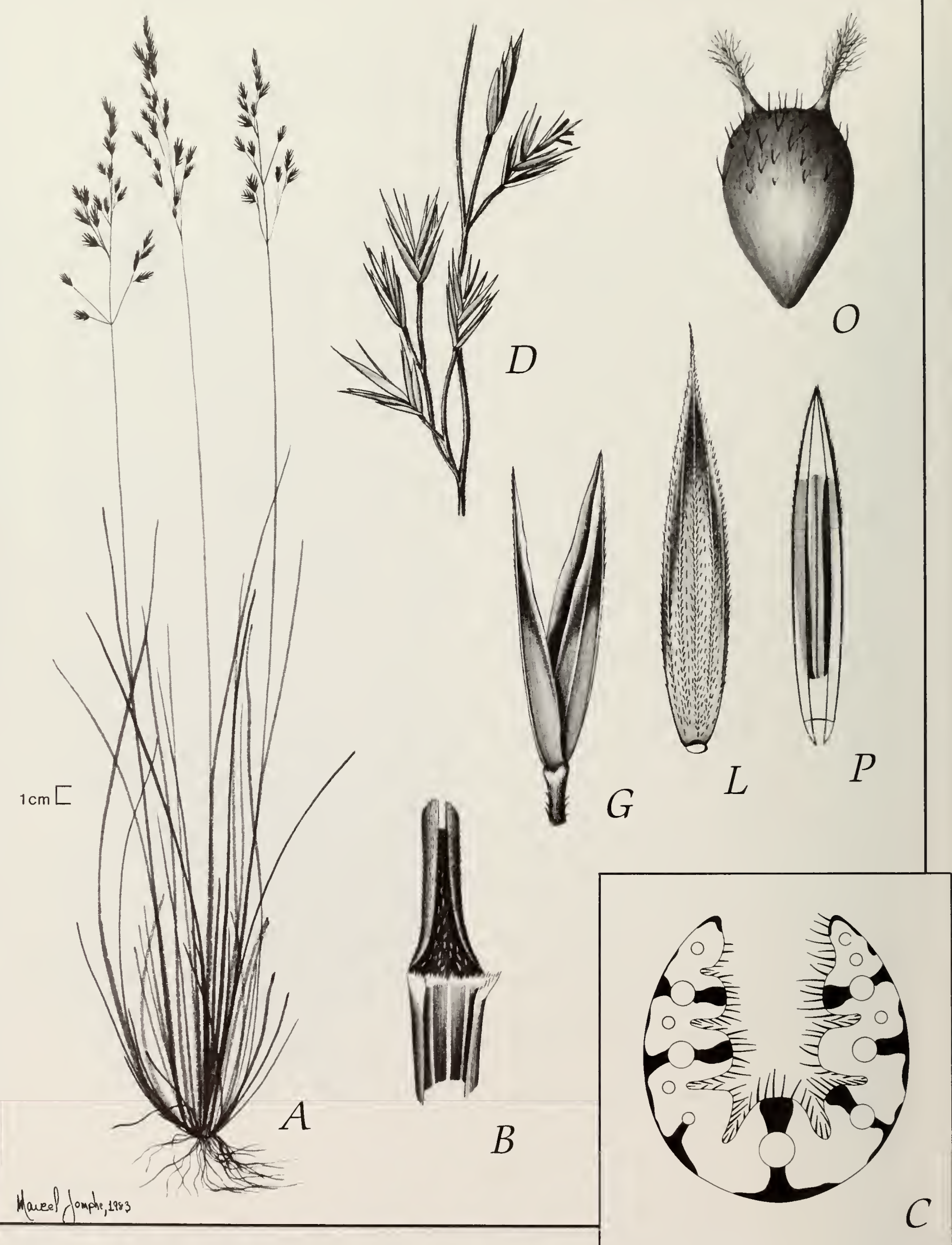

Plate 11 Festuca campestris. 


\section{Festuca campestris}

Festuca campestris Rydberg, Mem. N.Y. Bot. Gard. 1:57. 1900.

F. scabrella var. major Vasey, Contrib. U.S. Natl. Herb. 1:278. 1893.

F. altaica ssp. scabrella (Torrey in Hooker) Hultén, Fl. Alaska and Yukon 2:241. 1942.

F. altaica var. major (Vasey) Gleason, Phytologia 4:21. 1952.

F. altaica var. scabrella (Torrey in Hooker) Breitung, Am. Midl. Nat. 58:12. 1957.

F. doreana Looman, Budd's Flora Can. Pr. Prov.:128. 1979, nom. illeg.

\section{Mountain rough fescue Plate 11, Map 6}

Plants bluish gray-green, densely caespitose, rarely with rhizomes. Culms (30-)40-90(-140) cm high; nodes never exposed; internodes scabrous. Dead blades breaking off at collars leaving entire sheaths that persist for several years. New shoots intravaginal or rarely extravaginal. Living sheaths usually bright purple, open, glabrescent. Auricle position usually with distinct erect swelling. Ligule distinctly erose ciliate, 0.1-0.5 mm long. Blades erect, stiffish, plicate or flat, 14-45 cm long, $1.2-3.2 \mathrm{~mm}$ wide when flat, abaxially scabrous; blade of flag leaf 3-6.5 cm long. Blade anatomy in cross section; veins (3-)5-7 large, 5-11 small; ribs 7-11; sclerenchyma girders present, with abaxial sclerenchyma forming an interrupted to almost continuous ring.

Panicle 5-18 cm long, with stiffly spreading branches; longest branches of inflorescence (2.5-)4.4-7 cm long, rounded or angular in cross section, with trichomes over whole surface. Spikelets yellowish or gray-green, 8-12 mm long, with (3-)4-5(-7) florets. Glumes shorter than spikelets, shorter than adjacent lemma, unequal, glabrous or scaberulous at a pex only; lower glume $1(-3)$ veined, $4.5-7.5(-8.5) \mathrm{mm}$ long; upper glume (1-)3 veined, 5.3-8.2(-9) $\mathrm{mm}$ long. Lemma scabrous, (6-)7-8.5(-10) $\mathrm{mm}$ long, veins not prominent; awn $0.5-1.5 \mathrm{~mm}$ long. Palea pubescent between keels towards apex. Lodicules with one or more marginal teeth, occasionally with trichomes. Anthers (3.3-)4.5-6 mm long; top of anthers lying towards end of palea. Ovary apex pubescent, usually with more than 20 trichomes.
$2 n=56($ Bowden 1960).

Distribution outside Canada: Washington, Oregon, Idaho, and Montana.

\section{Discussion}

One of the five native fescues in western Canada that are very important for livestock grazing, $F$. campestris has been extensively studied by rangeland ecologists and botanists It was long known, with $F$. hallii, under the name of $F$. scabrella (hence the name rough fescue), although Alexeev (1985) did not distinguish $F$. campestris from $F$. hallii even at a subspecific level. The analysis of typification of the name $F$. scabrella by Harms (1985) suggested that "the presumed geographic location and possible habitat of the type collection, allows that it is most likely, although still some what tentatively that of $F$. campestris Rydb." If so, the name $F$. scabrella would have priority. (See also the comments under $F$. altaica and $F$. hallii.)

$F$. campestris is a dominant component in a number of grassland associations in southern Alberta and British Columbia (Looman 1969, 1982). In their review of rangeland production in southern Alberta, Smoliak et al. (1985) found the $F$. campestris grassland in the foothills near Stavely to be the most productive of the rangelands surveyed. Looman (1982) characterized the $F$. campestris grasslands (Agropyrion spicatae alliance) as having cooler and moister spring climate than other fescue grasslands. 


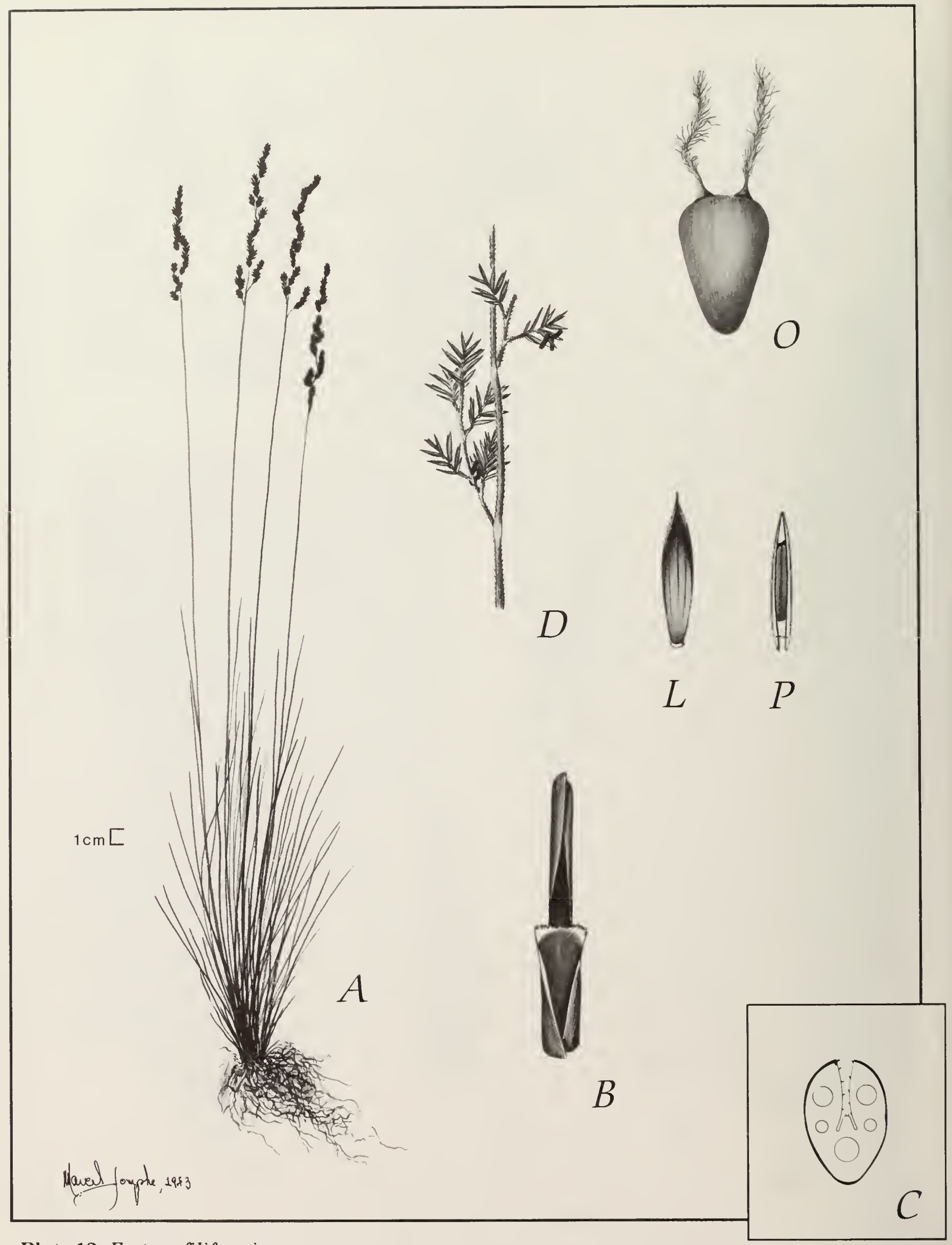

Plate 12 Festuca filiformis. 


\section{Festuca filiformis}

Festuca filiformis Pourret, Mém. Acad. Roy. Sci. Toulouse 3:319. 1788.

F. capillata Lamark, Fl. Fr. 3:597. 1778, nom. illeg.

F. tenuifolia Sibthorp, Fl. Oxon.:44. 1794.

F. ovina var. capillata (Lamark) Alefeld, Landw. Fl.:354. 1866.

F. ovina var. tenuifolia (Sibthorp) Roemer \& Schultes, Syst. Veg. 2:714. 1817.

\section{Hair fescue, fine-leaved sheep fescue Plate 12, Map 7}

Plants densely caespitose, bluish or yellowish green. Culms $18-40(-55) \mathrm{cm}$ high, without rhizomes; nodes usually exposed; internodes strongly scabrous or puberulent. New shoots intravaginal. Dead sheaths prominent at base of plants, not splitting. Living sheaths open, rounded, glabrous or glabrescent with minute trichomes, rarely with any purple pigments. Auricle position with a distinct erect swelling. Ligule erose, ciliate, $0.15-0.3 \mathrm{~mm}$ long. Blades setaceous or threadlike, plicate, (5-)11-23(-30) cm long; blade of flag leaf $0.5-5 \mathrm{~cm}$ long; abaxial epidermis scabrous at least towards tip. Blade anatomy in cross section $0.2-0.4 \times 0.3-0.6 \mathrm{~mm}$; veins 3 large, $0-4$ small, with 1 central rib; sclerenchyma forming continuous or almost continuous abaxial ring.

Panicle 1-4(-7) cm long, open or narrowly contracted; branches $0.5-1.5(-2) \mathrm{cm}$ long, angular in cross section, with trichomes over the entire surface. Spikelets yellowish green, $3-6(-6.5) \mathrm{mm}$ long, with 2-6 florets. Glumes shorter than spikelets, unequal, glabrous or with few scaberulous trichomes at apex; margins erose; lower glume with 1 vein, 1-2.5 mm long; upper glume 3 vẹins, (1.7-)2.3 $(-3.9) \mathrm{mm}$ long. Lemmas dorsally rounded, glabrous or scaberulous only at apex, 2.3-4 $(-4.4) \mathrm{mm}$ long, awnless or with arista to $0.4 \mathrm{~mm}$ long. Paleas with very few trichomes between keels at apex only, 2.3-3.7(-4) mm long. Lodicules with one or more marginal teeth, without trichomes. Anthers appearing about half as long as paleas, 1.5-2.2 $\mathrm{mm}$ long. Ovary apex glabrous.

$2 n=14,28$ (McNeill and Dore 1976).

Distribution outside Canada: Native in Europe to Asia Minor and North Africa. Introduced in many countries.

\section{Discussion}

Hair fescue occurs only sporadically in Canada except in Nova Scotia and southern New Brunswick where it is adventive in ruderal habitats and may even become a pest in dry sandy or rocky areas. Its introduction here, as in many places in the world, is the result of old turf or forage plantings. It may still be present as a contaminant in some seed mixes.

Under poor conditions $F$. filiformis may persist for many years as substantial but nonflowering tufts. Vegetative plants are easy to distinguish by the dense tufts of light brown, persistent sheaths and the fine leaf blades. In cross section the blade has no ribs and the sclerenchyma lies in a continuous, more or less even, subepidermal band. Only $F$. saximontana is likely to approach this combination of characteristics. 


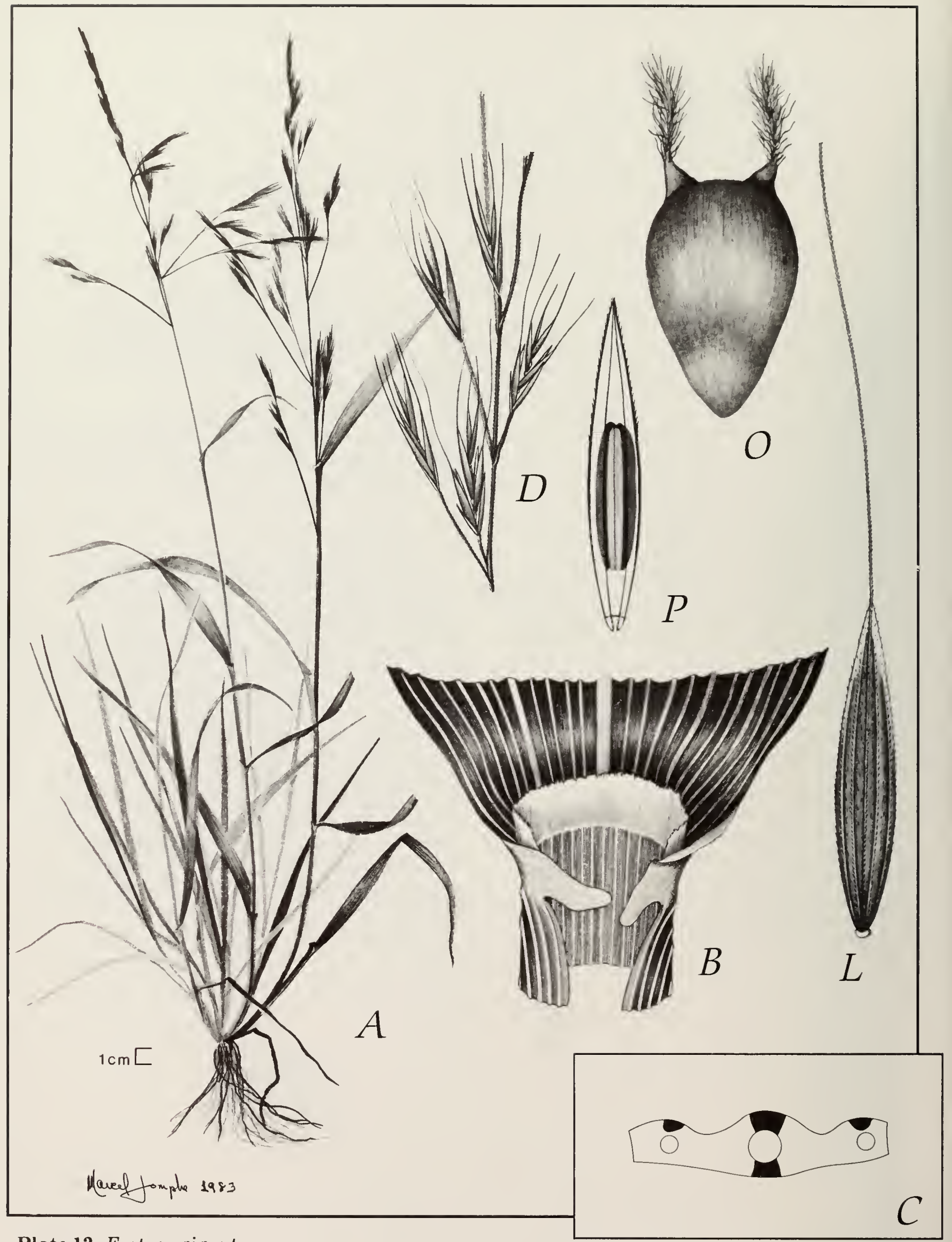

Plate 13 Festuca gigantea. 


\section{Festuca gigantea}

Festuca gigantea (L.) Villars, Hist. Pl. Dauph. 2:110. 1787.

Bromus giganteus L., Sp. Pl.:77. 1753.

\section{Giant fescue}

Plate 13, Map 8

Plants forming dark green tufts, without rhizomes. Culms $45-150 \mathrm{~cm}$ high, erect; nodes exposed, deep purple; internodes glabrous or with retrose scaberulous trichomes. Auricles clawlike, without cilia. Ligule membranous, $0.5-2.5 \mathrm{~mm}$ long. Blades flat, lax, 6-18 mm wide; adaxial epidermis glabrous or scaberulous; abaxial epidermis glabrous; sclerenchyma girders present.

Panicle 8-50 cm long; branches usually in pairs, unequal, with the shorter one having several spikelets; branches spreading, flexuous, angular, with trichomes on the angles.

Spikelets 8-13(-20) mm long, towards ends of branches, with 3-10 florets. Glumes much shorter than spikelets, unequal, rounded, scaberulous at apex only; margins broadly hyaline, entire; lower glume 1 vein, 4-7 $\mathrm{mm}$ long; upper glume 3 veins, $5-8 \mathrm{~mm}$ long. Lemmas rounded, scaberulous, mainly towards the apex, 6-9 mm long; awn straight or flexuous, $10-18 \mathrm{~mm}$ long. Paleas as long as lemmas, glabrous between keels. Lodicules with marginal teeth, without trichomes. Anthers 2.5-3 mm long, about half length of palea. Ovary apex glabrous.
$2 n=28,42$ (Alexeev 1983).

Distribution outside Canada: The native range of Festuca gigantea extends through most of Europe to central Asia (except the extreme north) south to Asia Minor and the Himalayas.

\section{Discussion}

Dubé (1983) first reported the occurrence of this species in Canada and gave evidence to suggest that it has become naturalized from ornamental cultivation in two localities in southern Quebec and one locality in New York State (Map 8 after Dubé 1983). The colony at Quebec City occurs in a limited area, in the shade of disturbed Acer saccharinum woods, on dry clay soil at the base of the limestone bluffs along the St. Lawrence River.

Giant fescue is a common grass of moist, open woodlands and shaded places in its native Eurasia. It is frequently offered in the horticultural trade for ornamental plantings in shaded sites. The discovery of further sites of localized persistence is expected. 


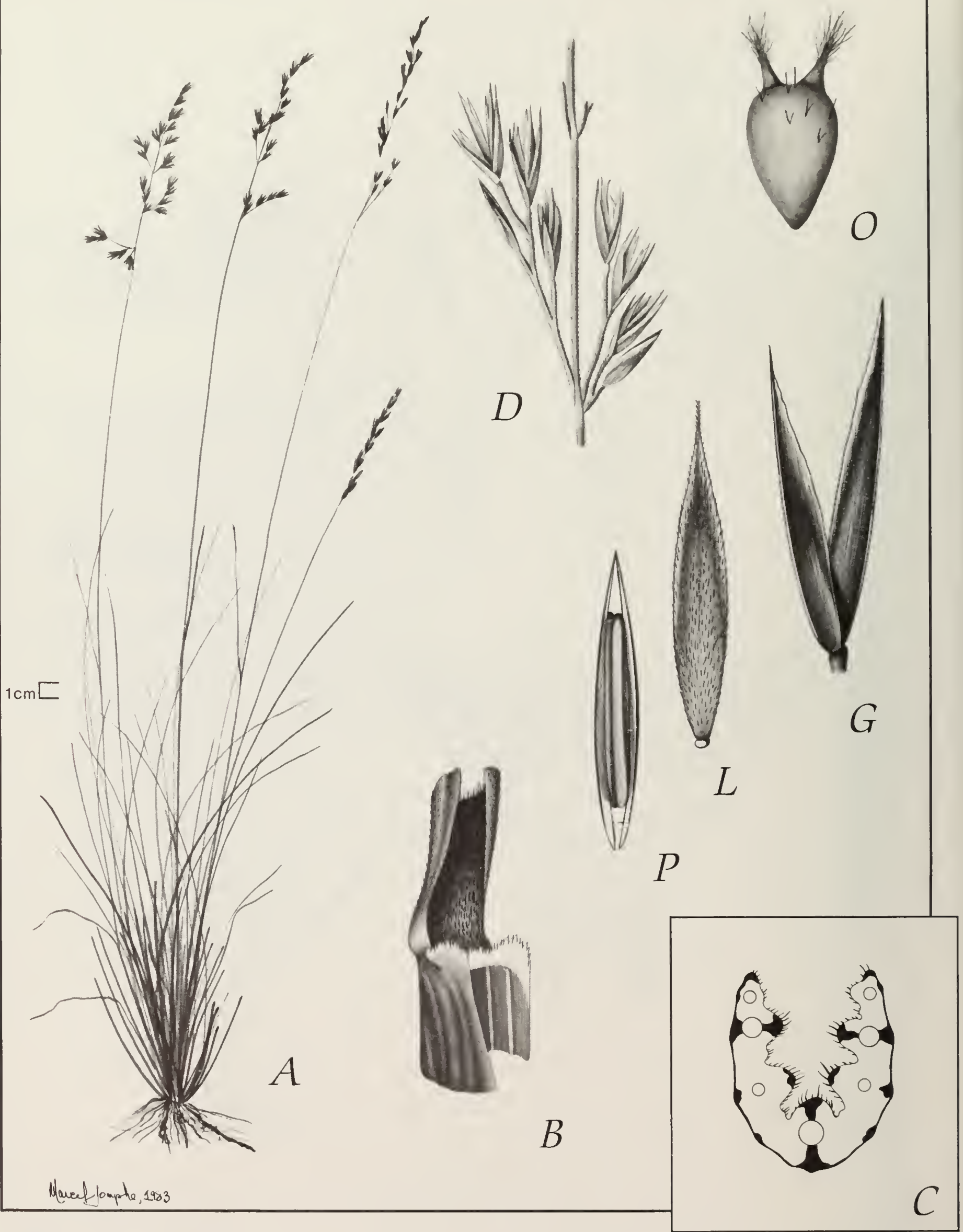

Plate 14 Festuca hallii. 


\section{Festuca hallii}

Festuca hallii (Vasey) Piper, Contrib. U.S. Natl. Herb. 10:31. 1906.

Melica hallii Vasey, Bot. Gaz. 6:296. 1881.

F. confinis ssp. rabiosa Piper, Contrib. U.S. Natl. Herb. 10:41. 1906.

F. altaica subvar. hallii (Vasey) Saint-Yves, Candollea 2:271. 1925.

F. scabrella ssp. hallii (Vasey) W.A. Weber, Univ. Colo. Stud. Ser. Biol. 7:8. 1961.

F. altaica ssp. hallii (Vasey) Harms, Madroño 32:9. 1985.

\section{Plains rough fescue \\ Plate 14, Map 9}

Plants bluish or gray-green bunchgrasses, with short rhizomes. Culms (18-)20-65 $(-85) \mathrm{cm}$ high; nodes never exposed; internodes scaberulous. New shoots arising intravaginally and extravaginally. Dead sheaths persisting at base of plant. Living sheaths usually purplish, open, glabrescent or scaberulous. Auricule position usually with a distinct erect swelling. Ligule erose ciliolate, $0.3-0.6 \mathrm{~mm}$ long. Blades stiffish, usually plicate, $10-35 \mathrm{~cm}$ long, with 5-7 ribs; blade of flag leaf $1.5-3(-5) \mathrm{cm}$ long. Blade anatomy in cross section $0.4-0.8 \times 0.6-0.9 \mathrm{~mm}$; veins 3 large, 4-5 small; abaxial sclerenchyma usually continuous or almost continuous, commonly uniform in thickness.

Panicle 6-16 cm long; branches stiffly erect, rounded or angular in cross section, with trichomes over whole surface; longest branch of inflorescence $2-4(-7) \mathrm{cm}$ long. Spikelets graygreen, 7-9.5 mm long, with 2 fertile florets and $0-2$ sterile florets. Glumes as long or almost as long as first floret, subequal, glabrous, margins erose ciliate; lower glume 1-3 veins, (5-)6.5-8 (-9.5) $\mathrm{mm}$ long; upper glume 3 veins, $6.2-8.3$ $(-9.5) \mathrm{mm}$. Lemma scabrous; veins not prominent, 5.5-7(-9) $\mathrm{mm}$ long; awn $0.5-1.3 \mathrm{~mm}$ long. Palea pubescent between keels. Lodicules, glabrous with or without marginal teeth. Anthers 4-6 $\mathrm{mm}$ long, with tops lying towards apex of paleas. Ovary apex pubescent, usually with fewer than 20 trichomes.

$2 n=28$ (Pavlick and Looman 1984).
Distribution outside Canada: Montana to North Dakota, south to Colorado.

\section{Discussion}

There are many morphological and ecological differences between $F$. hallii and mountain rough fescue, $F$. campestris (Johnston and Cosby 1966, Looman 1982, Pavlick and Looman 1984, Harms 1985). The two species are separated by altitude in southern Alberta. The lower, plains species, $F$. hallii, has smaller spikelets, stiffly erect panicle branches, and creeping rhizomes. Other differences include geographic distribution, chromosome number, and growth patterns. Looman (1982) made the interesting observation that, although $F$. hallii flowers 2-3 weeks earlier than $F$. campestris, the seed matures at a later date.

The densely tufted, bunchgrass habit of the rough fescues is resistant to light fire and moderate grazing. All three species serve as important native forage grasses in western Canada and are often dominant species in their grassland communities.

Mass flowering of $F$. hallii has been investigated at the unplowed Kernen Prairie, near Saskatoon (Toynbee 1987). The control of this irregular boom-and-bust cycle of fruit production is not known. Toynbee (1987) speculated that it may be the result of a combination of warm spring temperatures, few killing frosts, and early heat penetration of the soil. 


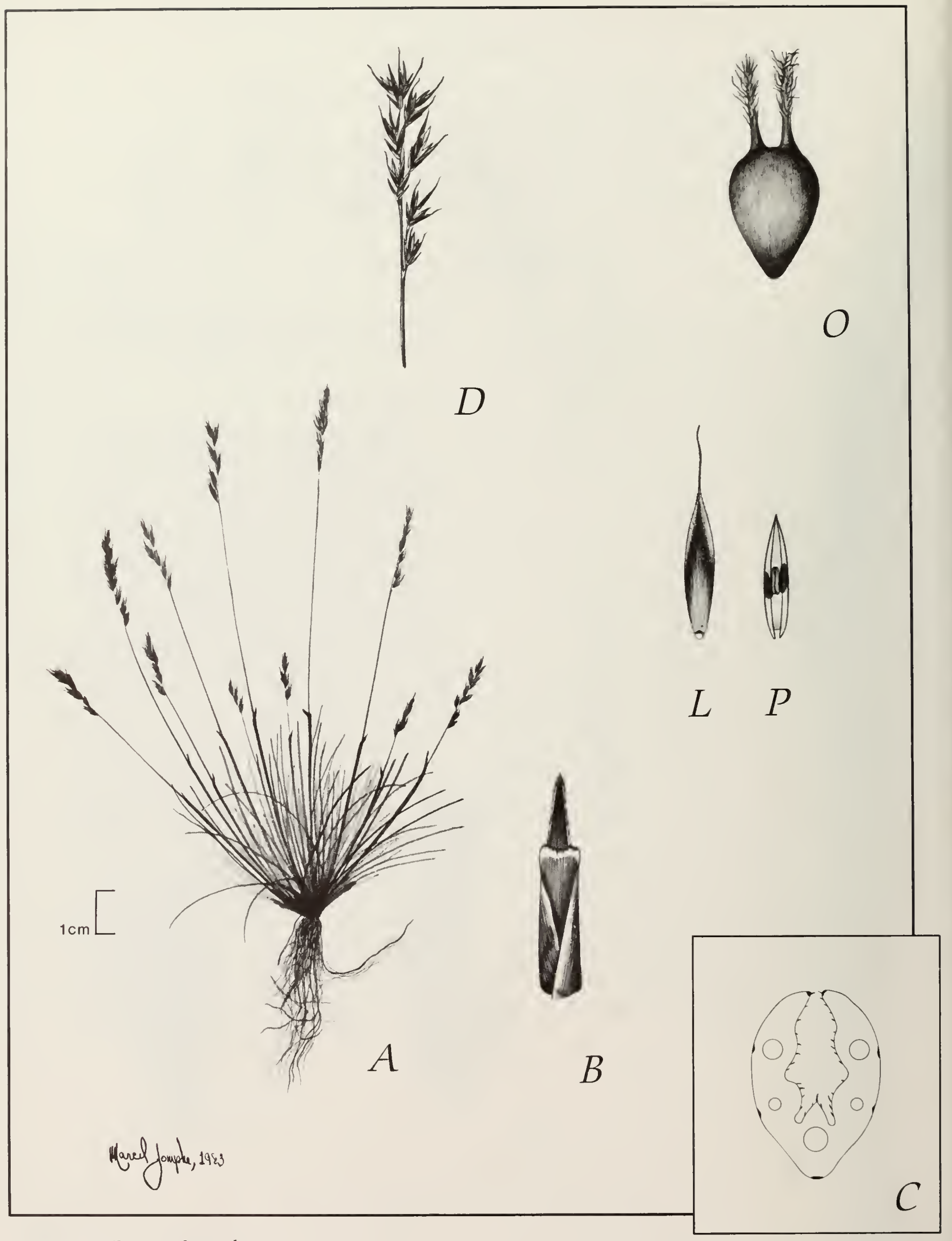

Plate 15 Festuca hyperborea. 


\title{
Festuca hyperborea
}

Festuca hyperborea Holmen ex Frederiksen, Bot. Not. 130:274. 1977.

\author{
Northern fescue \\ Plate 15, Map 10
}

Plants loosely caespitose, with at least outer culms of large tufts geniculate or semiprostrate, glaucous or pruinose, with or without purple pigments at base of plants. Culms to twice length of basal leaves but often not fully exsert from leaf sheath, 5-15(-20) cm high; nodes usually not exposed; in ternodes glabrous. Dead sheaths slowly splitting into fibers often obscured by the dense tufting and recurved leaves of short plants. Living sheaths closed at least half their length, rounded, glabrous; flag leaf sheath somewhat inflated. Auricle position with or without a distict swelling. Ligule minutely erose, $0.1-0.3 \mathrm{~mm}$ long. Blades stiffish; blade of flag leaf characteristically very short, $0.05-0.15$ $(-1.0) \mathrm{cm}$ long. Blade anatomy in cross section $0.4-0.65 \times 0.5-0.85 \mathrm{~mm}$; veins 3 large, 1-4 small; ribs (3-)5; sclerenchyma in 3-5 very slender strands.

Panicle erect, spikelike, 1-2(-2.5) cm long, about $0.5 \mathrm{~cm}$ wide; spikelets few, ascending; rachis branches rounded or angular in cross section, with sparse trichomes. Spikelets 4.2-5.5(-7) mm long, with 3-4(-6) florets. Glumes shorter than spikelets, unequal, dorsally rounded, glabrous, with erose or ciliate margins; lower glume 1 vein, $2-2.5 \mathrm{~mm}$ long; upper glume 3 veins, $2.7-3.5 \mathrm{~mm}$ long. Lemma rounded on back, scaberulous at apex, 3-3.5 (-4.4) $\mathrm{mm}$ long; awn short, subterminal, commonly curved or bent, (0.5-)1.4-2 mm long. Palea sparsely pubescent between keels, 3-3.5 mm long. Lodicules toothed, without trichomes. Anthers 0.5-0.8 mm long, less than one-third of length of palea. Ovary apex glabrous.
$2 n=28,42$ (Holmen 1952, Mosquin and Hayley 1966, Hedberg 1967).

Distribution outside Canada: Circumpolar arctic and subarctic species.

\section{Discussion}

This species occurs on exposed ground, often with unstable substrates, such as frost boils, flood plains, gravel slopes, and around animal burrows.

Festuca hyperborea was first recognized in northern Greenland by Holmen (1952). He found the tetraploid $F$. hyperborea sufficiently distinct to justify the rank of species. Features distinguishing $F$. hyperborea from $F$. brachyphylla include the flag leaf with a very short blade and an inflated (very loose) sheath, relatively wide and straight leaf blades in the vegetative shoots, broad glumes, small panicles with one spikelet per branch, less scabrous panicle branches, an often semiprostrate nature, and lighter color. Markgraf-Dannenberg (1980) described the leaves as having dense, short hairs, but this character is not conspicuous on Canadian material.

Frederiksen (1977) observed that $F$. hyperborea is closely related to $F$. brachyphylla and some morphologically intermediate specimens are found. She pointed out that the difference in chromosome numbers must impose strong reproductive isolation.

Löve and Löve (1956) reported possible hybrids with $F$. richardsonii in Iceland $(2 n=35,49)$. (See also comments under $F$. brachyphylla and F. brevissima.) 


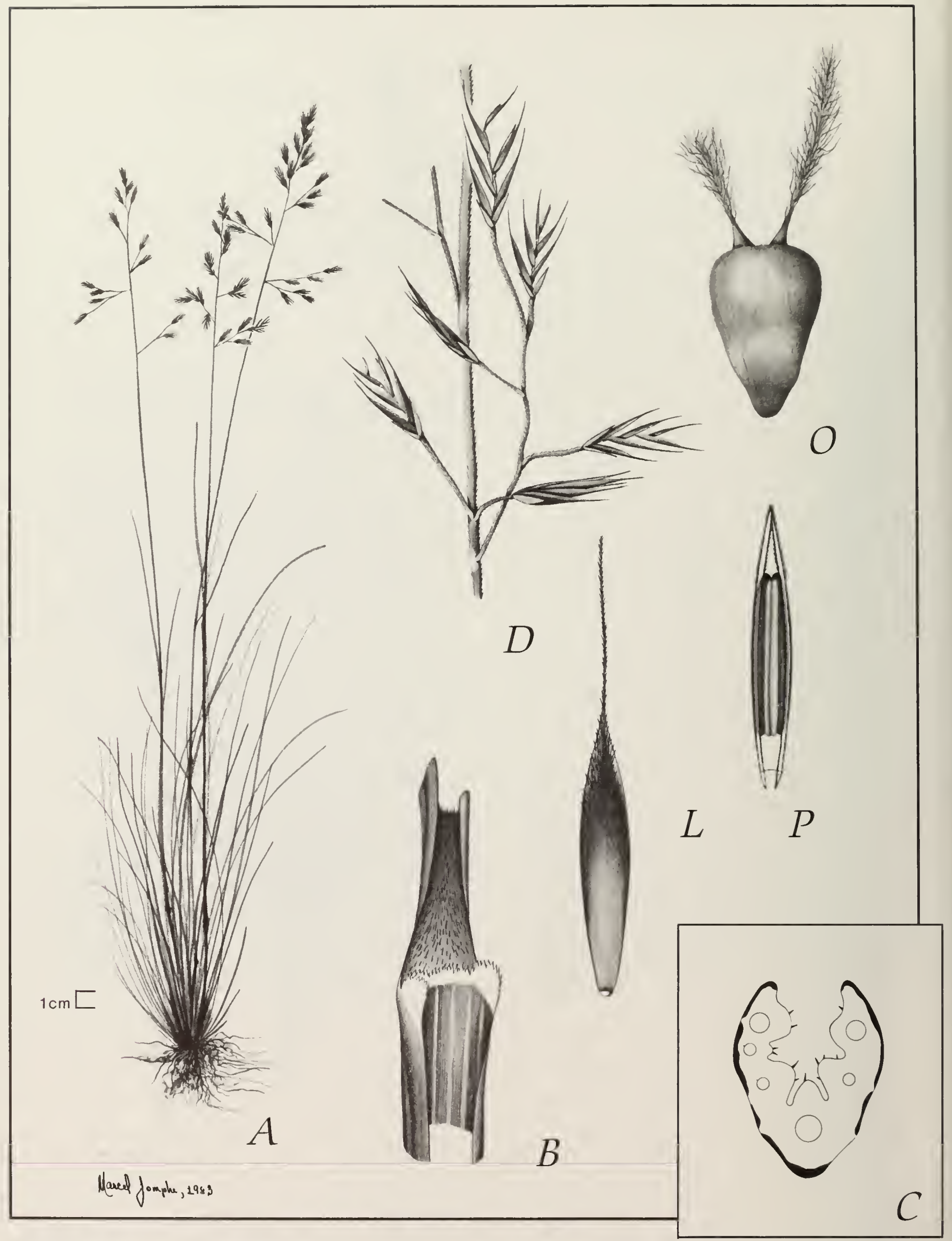

Plate 16 Festuca idahoensis. 


\section{Festuca idahoensis}

Festuca idahoensis Elmer, Bot. Gaz. 36:53. 1903.

F. ovina var. ingrata Hackel in Beal, Grasses N. Am. 2:598. 1896.

F. ovina var. columbiana Beal, Grasses N. Am. 2:599. 1896.

F. ovina var. oregona Hackel in Beal, Grasses N. Am. 2:599. 1896.

F. ingrata (Hackel in Beal) Rydberg, Bull. Torrey Bot. Club 32:608. 1905.

F. ovina ssp. ingrata (Hackel in Beal) Piper, Contrib. U.S. Natl. Herb. 10:28. 1906.

F. occidentalis var. ingrata (Hackel in Beal) Boivin, Nat. Can. (Que.) 94:505, 524. 1967

F. roemeri (Pavlick) Alexeev, Nov. Sist. Vyssh. Rast. 22:23. 1985.

\section{Idaho fescue}

Plate 16, Map 11

Plants caespitose, bluish or yellowish green. Culms 30-85(-100) cm high; nodes exposed; internodes glabrous or with minute trichomes, scaberulous or puberulent. Shoots intravaginal. Dead sheaths persisting. Living sheaths with or without purple pigments, open, rounded with a prominent midvein. Auricle position with a small erect swelling. Ligule minutely erose, higher on sides than in middle, $0.3-0.6 \mathrm{~mm}$ long. Blades setaceous, lax in moist conditions, stiffish when dry, (5-)15-30 $(-35) \mathrm{cm}$ long, abaxially glabrous to pubescent; blade of flag leaf (1.4-)3-7(-9.5) cm long. Anatomy of blade in cross section $0.4-0.8 \times$ $0.6-1.0 \mathrm{~mm}, 3-5$ large veins and $2-5$ small veins, ribs (1-)3-5, sclerenchyma in broad irregular bands.

Panicle narrow, (5-)7-12(-16) cm long; branches loosely compressed or spreading, angular in cross section, with trichomes on angles; longest branch of panicle (1.5-)

2.5-4.5 cm long. Spikelets 7.5-13.5 mm long. Glumes much shorter than spikelets, linear lanceolate to lanceolate, scaberulous towards apex; margins erose; lower glume 1 vein, 2.4-5 mm long; upper glume 3 veins, 3-6 $\mathrm{mm}$ long. Lemma dorsally rounded and glabrous at base, keeled towards scaberulous apex, 5-8 (-8.5) mm long; awn (1.5-)3-6(-7) mm long. Paleas distinctly pubescent between veins, 5-7.5 mm long. Lodicules with marginal teeth, glabrous or with trichomes. Anthers more than half the length of paleas, 2.5-4 mm long. Ovary apex glabrous.

$2 n=28$ (C. Crompton ined.).

Distribution outside Canada: South to California and Nevada.

\section{Discussion}

The recognition of $F$. idahoensis as a distinct species has been debated by Boivin (1967, 1981) and Cronquist et al. (1977). Pavlick (1983a) considered the suggestion by Boivin (1967) that $F$. idahoensis is a variety of $F$. occidentalis but concluded that they should be treated as two species. In their treatment of $F$. idahoensis, Cronquist et al. (1977) stated that " $F$. idahoensis is very closely related to $F$. ovina L. Some might regard it as a native low elevation phase of $F$ ovina: if so, the name $F$. ovina var. ingrata Hackel in Beal would be used." Certainly based on anatomy of the blade cross section, the suggestion that $F$. idahoensis is more closely related to $F$. ovina appears reasonable as the sclerenchyma is much thicker and often in an almost continuous band as in the $F$. ovina complex, whereas in $F$. occidentalis, the sclerenchyma is limited to much smaller, discrete strands opposite the vascular bundles and at the margins. In this character, $F$. occidentalis more closely resembles the $F$. rubra complex (Pavlick 1983a, Aiken et al. 1985). Many other features serve in distinguishing $F$. idahoensis from $F$. occidentalis including habitat (see discussion under $F$. occidentalis account), dense bunchgrass habit rather than loose tufts, glabrous ovary rather than pubescent ovary, and shorter anthers.

Festuca saximontana is readily distinguished from $F$. idahoensis by panicle shape and size, length of lemma awns, and length of anthers, but vegetative or immature specimens may be difficult to distinguish. 
Festuca idahoensis and $F$. saximontana produce both short and long leaves, which results in strikingly different height forms (for $F$. idahoensis the short form has leaves $5-15 \mathrm{~cm}$ long whereas the tall form has leaves $25-35 \mathrm{~cm}$ long). This phenomenon has been observed in $F$. saximontana in the Cariboo District of British Columbia (A. Roberts, personal communication) and in southern Alberta for $F$. idahoensis (S.G. Klumph, personal communication). A large difference in the productivity of the two forms has been observed during clipping experiments undertaken in Alberta rangelands (S. Smoliak, personal communication). Also spikelets of the tall form are typically reddish, whereas in the short form they are typically greenish (S. Smoliak, personal communication). Plants of $F$. idahoensis of short, tall, and intermediate heights from southern Alberta have been grown together for several years in Ottawa. Initially they appeared to retain their respective habit in the greenhouse, but after two growth seasons in uniform outdoor cultivation, the height difference was no longer evident. In Lethbridge, S. Smoliak (personal communication) has observed similar reactions in plants grown for 2 years in a greenhouse. The variablity in foliage size and production in $F$. idahoensis is most likely the result of microenvironmental factors.
Pavlick $(1983 a, b)$ stated that $F$. idahoens is from west of the Cascade Mountains in British Columbia and northwestern Washington differs from plants east of the Cascade Mountains in its coarse aspect, leaf morphology (in cross section usually with 7 veins versus usually with 5 veins), and panicle size (9.5$16 \mathrm{~cm}$ long versus $7-11 \mathrm{~cm}$ long). He referred these plants to $F$. idahoensis var. roemeri Pavlick. Alexeev (1985) suggested that the geographic isolation, ecological isolation (grass balds and openings in Quercus garryana woods rather than open grassland), and larger size warrant recognition of $F$. roemeri (Pavlick) Alexeev. Considerable variation occurs throughout the range of $F$. idahoensis and a continuum in these characters has been seen.

Idaho fescue is a grass that is highly palatable to livestock. It is an important range plant of open grasslands in southwestern Alberta and southern British Columbia. In the grassland referred to as the Pacific Northwest Bunchgrass habitat, Idaho fescue is codominant with Agropyron spicatum (Pursh) Scribner \& J.G. Smith (= Pseudoroegneria spicata (Pursh) A. Löve) and commonly with Festuca campestris. 



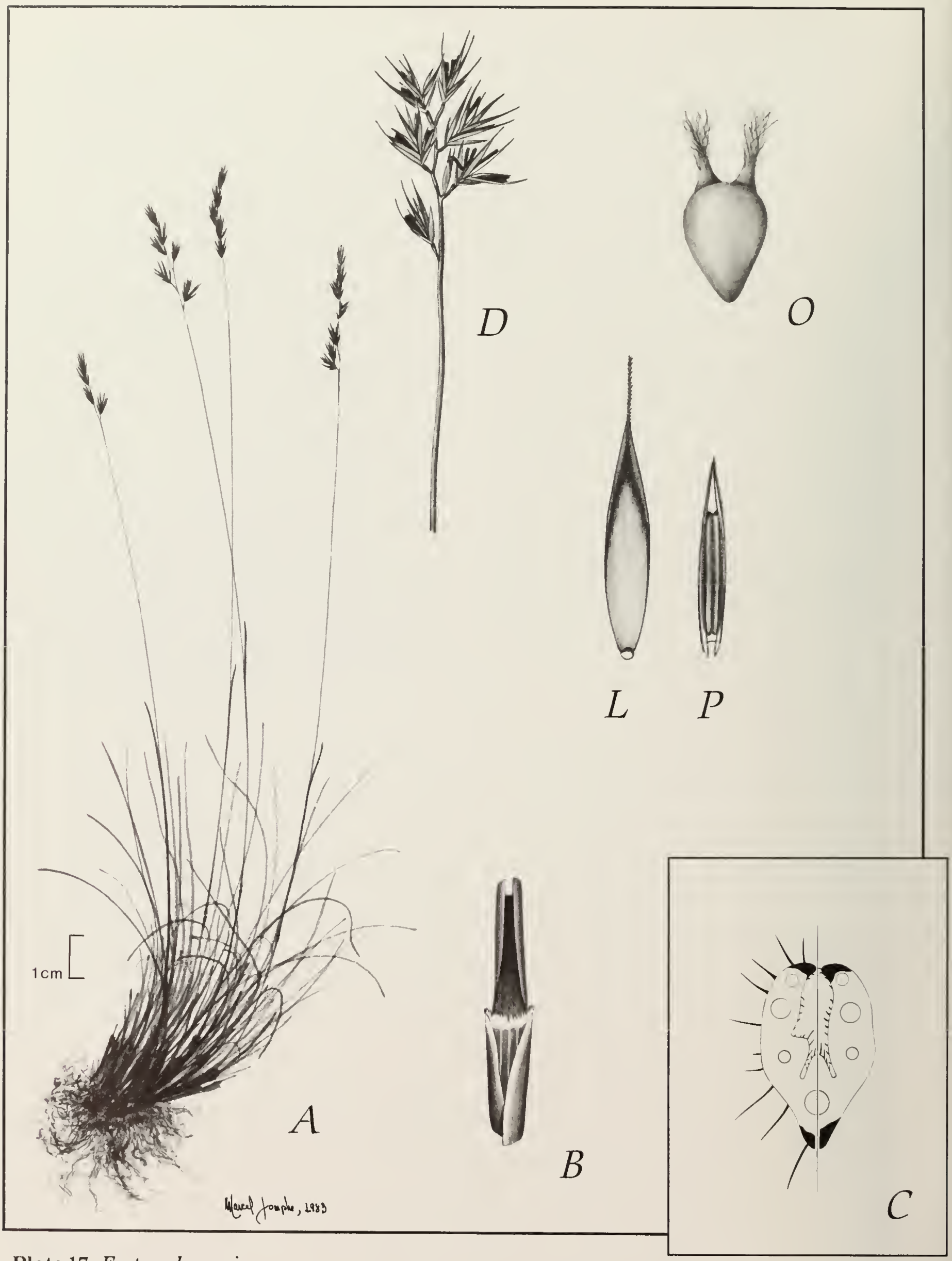

Plate 17 Festuca lenensis. 


\section{Festuca lenensis}

Festuca lenensis Drobov, Tr. Bot. Inst. Akad. Nauk SSSR 14:158. 1915.

F. auriculata Drobov, Tr. Bot. Inst. Akad. Nauk SSSR 14:159. 1915.

F. ovina ssp. alaskana Holmen, Bot. Not. 117:115. 1964, pro parte, quod descr. sed non typus.

\section{Plate 17, Map 12}

Plants caespitose, usually gray-green. Culms 10-35(-50) cm high; nodes sometimes exposed; internodes culm glabrous near base, pubescent (sometimes sparsely) below inflorescence. Dead sheaths prominent at base of plants, persistent, commonly in dense fascicles. Living sheaths usually without purple pigments, fused about half their length, glabrous to pubescent (usually on same plant), rounded with a prominent midvein. Auricle position usually with a distinct erect swelling. Ligules erose, ciliolate, $0.2-0.4 \mathrm{~mm}$ long. Blades glaucous, pruinose or green, stiffish, plicate, 4-10(-13) cm long, glabrous, scabrous and pubescent leaves commonly occurring on same plant; blade of flag leaf $0.35-2 \mathrm{~cm}$ long. Anatomy of blade in cross section (0.3-) 0.4-0.6 $\times 0.5-0.9 \mathrm{~mm}$; veins $5-7$; ribs 1-3; sclerenchyma strands 3 (at midrib and margins), commonly well-developed.

Panicle spreading or not at anthesis, $1.5-4(-5.5) \mathrm{cm}$ long, with 3-15 spikelets; branches angular, with trichomes mainly on angles. Spikelets (5-)6-9(-11) mm long, with 4-7 florets. Glumes shorter than spikelets, unequal or approaching subequal, rounded on back, glabrous, with or without ciliolate margins; lower glume 1 vein, 2.5-3.6(-3.8) $\mathrm{mm}$ long; upper glume 3 veins, 3-4.6 mm long. Lemmas lanceolate, rounded on back, glabrous, scabrous, or pubescent only at apex, 4-5.5 (-6) $\mathrm{mm}$ long; awn 1-2.6 m m long. Paleas pubescent between keels mainly towards a pex, as long as, or slightly longer than, the lemma. Lodicules glabrous, each usually with one large tooth. Anthers more than half as long as paleas, (2-)2.3-2.7(-3.5) $\mathrm{mm}$ long. Ovary apex glabrous. $2 n=14$ (B. Cummings, Agriculture Canada on: $F$. lenensis in valley west side of Cache Creek, Yukon, below flat-topped ridge with yellow cliffs, $68^{\circ} 15^{\prime} \mathrm{N}, 136^{\circ} 36^{\prime} \mathrm{W}$. S.G. Aiken \& K.I. McLachlan 87108, 25 Aug. 1987, CAN). Distribution outside Canada: Alaska, Far East (USSR) to Siberia and Mongolia ( $F$. auriculata sensu stricto west to the polar Urals).

\section{Discussion}

Festuca lenensis has previously been reported in North America under the names F. ovina ssp. alaskana (Porsild and Cody 1980) or $F$. auriculata (Löve and Löve 1975, Frederiksen 1978, Alexeev 1982), although Alexeev (1985) reports both from Canada. Holmen (1964) described the anthers of $F$. ovina ssp. alaskana as 2-3 $\mathrm{mm}$ long. However, Frederiksen's (1978) reexamination of the type material, as well as of other plants from the area, showed them to have short anthers, about $1 \mathrm{~mm}$ long, as well as anatomical characters of the sheath and leaf inconsistent with the description. She concluded that the taxon that Holmen typified was in fact $F$. brevissima. (See also comments under $F$. brachyphylla and F. brevissima.)

Among material of $F$. auriculata and $F$. lenensis from the Soviet Union (annotated by Alexeev in 1979) and from North America, a continuum in culm height has been observed. The limited number of Canadian specimens from this complex that have been examined have, for the most part, three well-developed bands of sclerenchyma and can be assigned to $F$. lenensis. Observations on North American material indicate a continuum in leaf pubescence and sclerenchyma characteristics. Pubescence is particularly variable, with single plants often bearing glabrous, scabrous, and pubescent leaves. Most Canadian and Alaskan specimens examined seem closer to the description and type of $F$. lenensis, although some, especially those from Canoe Lake in the Northwest Territories cited by Frederiksen (1978) have limited sclerenchyma. Forms with pubescent leaves have been given the name $F$. auriculata forma pilosa Vodopjanova. Proliferous forms have been found in Asia and described as $F$. auriculata ssp. choinobia (Egorova \& Siplivinsky) Tzvelev. 


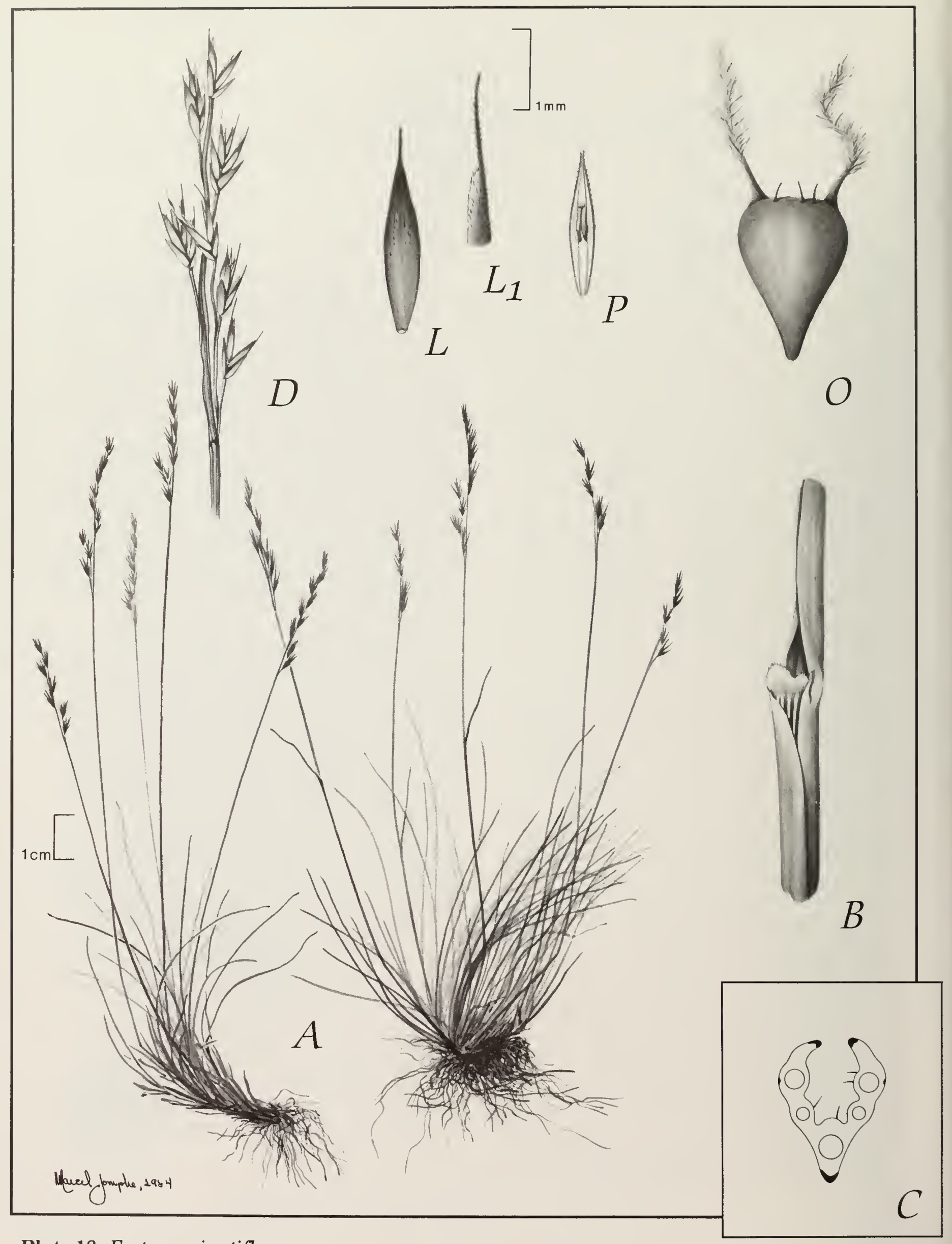

Plate 18 Festuca minutiflora. 


\section{Festuca minutiflora}

Festuca minutiflora Rydberg, Bull. Torrey Bot. Club 32:608. 1905.

$F$. brevifolia var. endotera Saint-Yves, Candollea 2:254. 1925.

$F$. brevifolia var. utahensis Saint-Yves, Candollea 2:257. 1925.

F. ovina var. minutiflora (Rydberg) Howell, Leafl. West. Bot. 6:151. 1951.

\section{Plate 18, Map 13}

Plants delicate, loosely or densely tufted, slightly bluish green. Culms (4-)7.5-20 $(-30) \mathrm{cm}$ high; nodes rarely or never exposed; internodes glabrous. Shoots intravaginal.

Dead sheaths not prominent at base of plant. Living sheaths usually without conspicuous purple, open, glabrous, rounded with a prominent midvein; sheaths of flag leaf somewhat inflated. Auricle position with a distinct erect swelling. Ligule $0.1-0.3$ $(-0.75) \mathrm{mm}$ long, indistinctly and sparsely erose. Blades fine, setaceous; blade of flag leaf $0.7-3.5 \mathrm{~cm}$ long; abaxial epidermis glabrous. Anatomy of blade in cross section $0.2-0.4 \times$ $0.3-0.8 \mathrm{~mm}$, with 3 large bundles, $0-2$ small bundles, 1-5 slender strands of sclerenchyma.

Panicle narrow, 1-4(-5) cm long; branches of rachis short, rounded or angular in cross section, almost glabrous or with sparse trichomes mainly on angles. Spikelets 2.5-5 mm long, with (2-)3-4(-5) florets. Glumes much shorter than spikelets, unequal, rounded on the back, sparsely scaberulous towards apex; margins either entire or erose only at apex; lower glume 1 vein, $1.3-2.5 \mathrm{~mm}$ long; upper glume 3 veins, $2-3.5 \mathrm{~mm}$ long. Lemma rounded, abruptly acuminate, sparsely scaberulous towards apex, 2-3.4(-4) mm long; awn (0.5-)0.7-1.5(-1.7) $\mathrm{mm}$ long. Lodicules glabrous with one or more marginal teeth. Anthers 0.5-1.2 mm long, one-third as long as palea or less. Ovary apex with scattered trichomes.

$2 n=28$ (Frederiksen 1979).

Distribution outside Canada: Scattered in alpine tundra and meadows and subalpine openings of the Rocky Mountains south to California and New Mexico (Frederiksen 1982).

\section{Discussion}

Rydberg (1905) described $F$. minutiflora as "more closely related to $F$. brachyphylla, but differs in the smaller spikelets, the more abruptly acuminate flowering glumes [lemmas], the shorter awns, the laxer panicle and the soft filiform leaves." Frederiksen (1979) added to his description, "top of caryopsis hairy, branches of the panicle glabrous or only slightly scabrous." Rydberg (1905) gave ligule length as $0.75 \mathrm{~mm}$, but all specimens examined have had shorter ligules.

This species may be more continuously distributed in alpine regions of the northern Rocky Mountains than is indicated in Map 13. Its similarity to $F$. brachyphylla and remote habitat have impeded the collection of specimens and have limited knowledge of its range. (See also comments under F. brachyphylla.) 


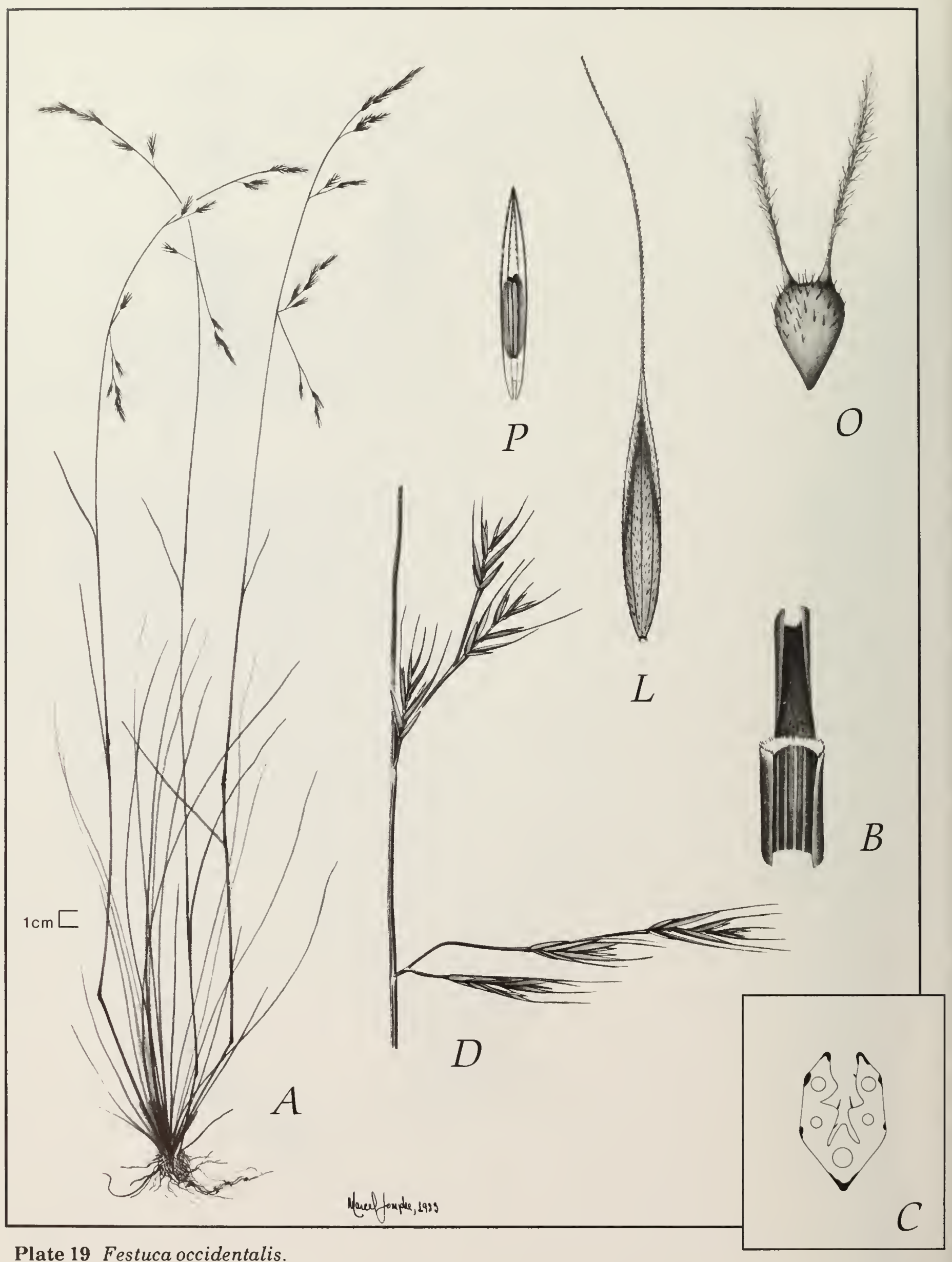




\title{
Festuca occidentalis
}

\author{
Festuca occidentalis Hooker, Fl. Bor. Am. 2:249. 1840 \\ F. ovina var. polyphylla Vasey in Beal, Grasses N. Am. 2:597. 1896.
}

\section{Western fescue \\ Plate 19, Map 14}

Plants densely to loosely tufted, without rhizomes, bright green to glaucous green. Culms (25-)50-110 cm high slender, with 2 exposed nodes; internodes glabrous. Shoots intravaginal. Sheaths open to near base, with or without purple pigments, glabrescent, rounded with prominent midvein. Auricle position with a distinct erect swelling. Ligule 0.1-0.4 mm long, minutely erose. Blades lax, numerous, filiform, plicate or subsetaceous. Anatomy of blade in cross section $0.24-0.5 \times$ $0.3-0.65 \mathrm{~mm}$; veins 3 large, $0-2$ small; ribs $1-5$, sometimes very prominent; sclerenchyma in $5-7$ strands.

Panicle open, flexuous, often somewhat drooping above, (5-)10-20 cm long, usually with 2 unequal and strongly reflexed branches at lower node; branches $1-5 \mathrm{~cm}$ long, angular in cross section with minute trichomes on and between ridges. Spikelets $6-10 \mathrm{~mm}$ long, with 3-5(-7) florets; rachilla visible at anthesis; internodes 1-1.5 mm long. Glumes unequal, variable even on same plant, usually sharply acute or acuminate, sometimes obtuse, glabrous, or scaberulous at apex; margins erose; lower glume 1 vein, $2-3.6 \mathrm{~mm}$ long; upper glume $1-2$ veins, $3-3.4(-4.4) \mathrm{mm}$ long. Lemmas oblong-lanceolate, membranous, dorsally rounded, scaberulous over entire surface or at apex only, 4.5-6.5 mm long; awn slender, flexuous, (3-)4.5-8(-12) $\mathrm{mm}$ long. Paleas with inflexed sides meeting in the middle when flattened, 4-5.5 mm long, distinctly pubescent between keels. Lodicules toothed, usually without marginal trichomes. Anthers 1-2 mm long, about one-third of palea length. Ovary apex densely pubescent.

$2 n=14,28,42,46,56,64,70$ (Hitchcock et al. 1969).

Distribution outside Canada: Montana to Washington, south to California, also northern Michigan and Wisconsin.

\section{Discussion}

Hitchcock and Chase (1951) stated that $F$. occidentalis occurs on "dry, rocky wooded slopes and banks" in the northwestern United States. Pavlick (1983a) observed that
$F$. occidentalis is a more mesic species than $F$. idahoensis, occurring always in forested areas and glades and in at least partial shade. In Michigan, $F$. occidentalis occurs in open, commonly rocky woods, wooded dunes (with pines), cedar-fir woods, and thick ets (usually on calcareous sites) of aspens and hardwoods (Voss 1972). Dore and McNeill (1980) stated that $F$. occidentalis is highly localized in Ontario where it occurs abundantly only on the Bruce Peninsula. It also occurs in woods on noncalcareous substrates along the west and north shores of Georgian Bay in Algoma, Muskoka, and Parry Sound districts. The fine foliage, small tufts, diffuse inflorescence, and, usually, sparse occurrence in shade make it difficult to detect in the field. Despite its occurrence along much of the shores of the northern Great Lakes, it is rarely collected in this part of Canada (Argus and White 1977). It is known in Alberta only from Waterton Lakes National Park.

Piper (1906) stated, "this species has been generally misunderstood, principally owing to the character assigned to the glumes of being short, obtuse and ciliate." He claimed that specimens in the Gray Herbarium agree perfectly with Hooker's characterization, but that the "character is ... unreliable, most specimens having longer and usually acute glumes."

Hitchcock et al. (1969) stated that, "it is believed that $F$. idahoensis hybridizes with $F$. occidentalis since Hitchcock 8015 , Scatter Creek Trail, Kittas Co., Washington, includes plants intermediate between the two." Pavlick (1983a) searched WTU but could neither locate this collection nor find evidence of intermediates during his study of western material. Specimens with immature inflorescences may be difficult to distinguish. The leaves of $F$. occidentalis are usually finer and the position of the narrow strands of sclerenchyma gives an angular outline to cross sections of the leaf whereas in $F$. idahoensis the sclerenchyma is in broader strands and the leaf is rounded (Aiken et al. 1985). More definitive characters are the glabrous ovary and larger anthers of $F$. idahoensis. 


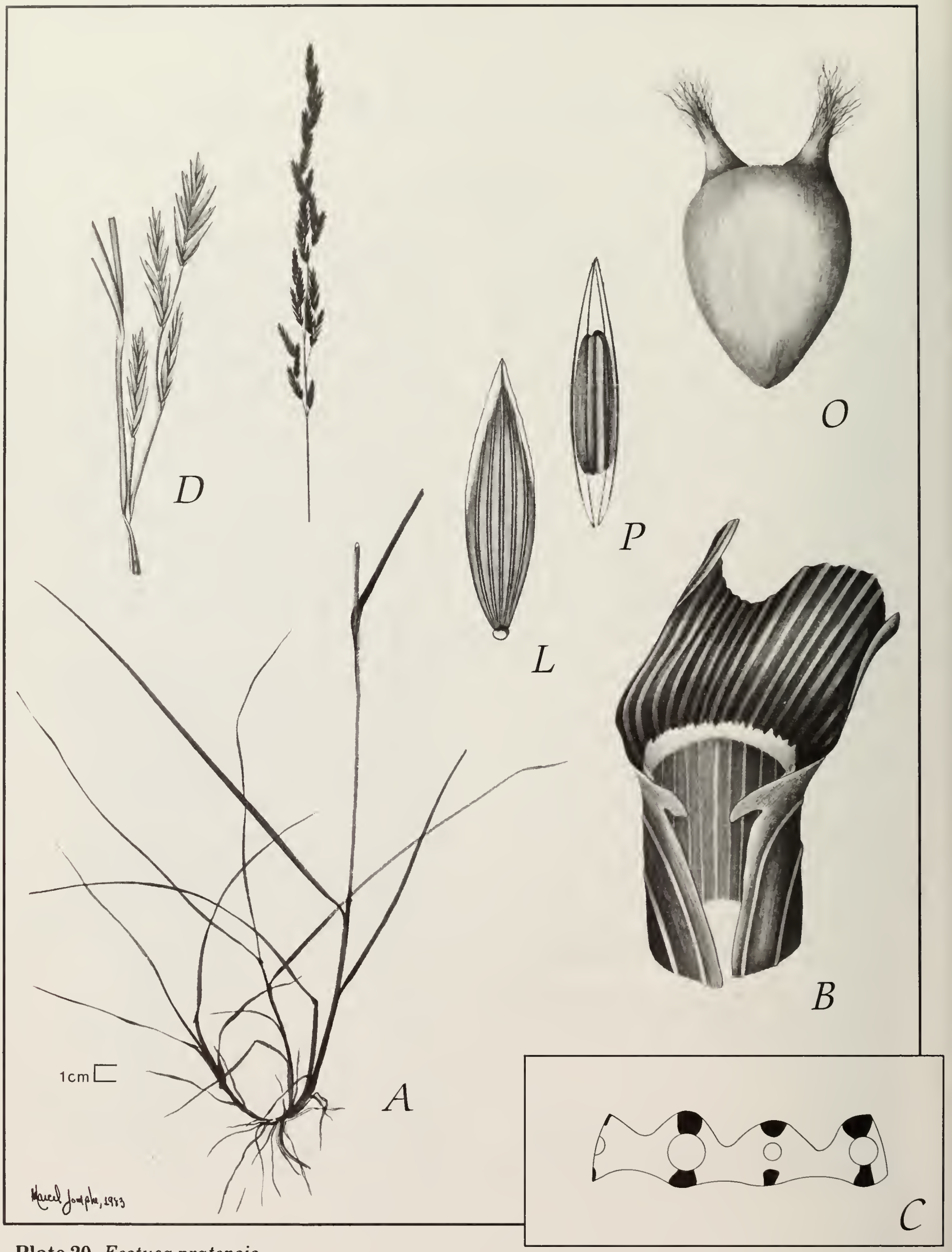

Plate 20 Festuca pratensis. 


\section{Festuca pratensis}

Festuca pratensis Hudson, Fl. Angl.:37. 1762.

$F$. elatior auct. non L.

Schedonorus pratensis (Hudson) Beauvois, Ess. Agrost.:177. 1812.

F. americana (Persoon) F.G. Dietrich, Vollst. Lex. Gartn. Bot. Nachtr. 3:332. 1817.

F. elatior var. pratensis (Hudson) A. Gray, Man. Bot. 5:634. 1867.

F. elatior ssp. pratensis (Hudson) Hackel, Bot. Centralbl. 8:407. 1881.

\section{Meadow fescue, English bluegrass, Dover grass Plate 20, Map 15}

Plants loosely tufted, with or without short rhizomes. Culms $30-100(-120) \mathrm{cm}$ high; nodes exposed; internodes glabrous. Dead sheaths brown, not prominent at base of plants, splitting into fibers. Shoots extravaginal. Living sheaths with or without purple pigments, open, rounded, glabrous. Auricles prominent, 0.7-1.1 mm long, clawlike, glabrous. Ligule erose, $0.2-0.4 \mathrm{~mm}$ long. Blades lax, flat or loosely involute, $10-20 \mathrm{~cm}$ long, 2-7 $\mathrm{mm}$ wide; blade of flag leaf (7-) 10-15 cm long; adaxial epidermis puberulent or glabrous; abaxial epidermis glabrous or scaberulous, long cells without interspersed short cells.

Panicle closed after flowering, 6-20 $(-22) \mathrm{cm}$ long, narrow; lowest node of panicle with 2 branches; longer branch $3.5-6.5 \mathrm{~cm}$ long, with 4-6 spikelets; shorter branch with 1(-3) spikelet(s); branches angular in cross section, with trichomes prominent on angles. Spikelets cylindric to oblong, (8.5-)9-12(-15) mm long, with (2-)4-10(-12) florets. Glumes obtuse, much shorter than spikelet, unequal, dorsally rounded, glabrous, or slightly scabrous towards the apex, margins hyaline, entire; lower glume $1-3$ veins, $2-4.5 \mathrm{~mm}$ long; upper glume $3(-5)$ veins, $3-5.5 \mathrm{~mm}$ long. Lemma dorsally rounded, glabrous or scaberulous near apex; lateral veins not reaching to hyaline apex; margins hyaline, $5-8 \mathrm{~mm}$ long, awnless or with an arista $<2 \mathrm{~mm}$ long. Palea glabrous between keels, 6-7 mm long. Lodicules toothed, without trichomes. Anthers about half length of palea, (1.5-)2-4 mm long. Ovary apex glabrous.

$2 n=14,28,42$ (Bowden 1960, Taylor and Mulligan 1968, Markgraf-Dannenberg 1980). Distribution outside Canada: Native to nonarctic Eurasia. Introduced and naturalized in many temperate countries.

\section{Discussion}

Festuca pratensis, a valuable and nutritious pasture species, is not as productive or persistent as tall fescue in North America. It is, however, more palatable to livestock than $F$. arundinacea because of its softer texture and paucity of silica deposits. Once popular as a forage in Canada it is now cultivated less frequently. The distribution of meadow fescue is restricted by its moisture requirements. As with tall fescue, it is not grown without irrigation on the prairies. (See also comments under $F$. arundinacea.) 


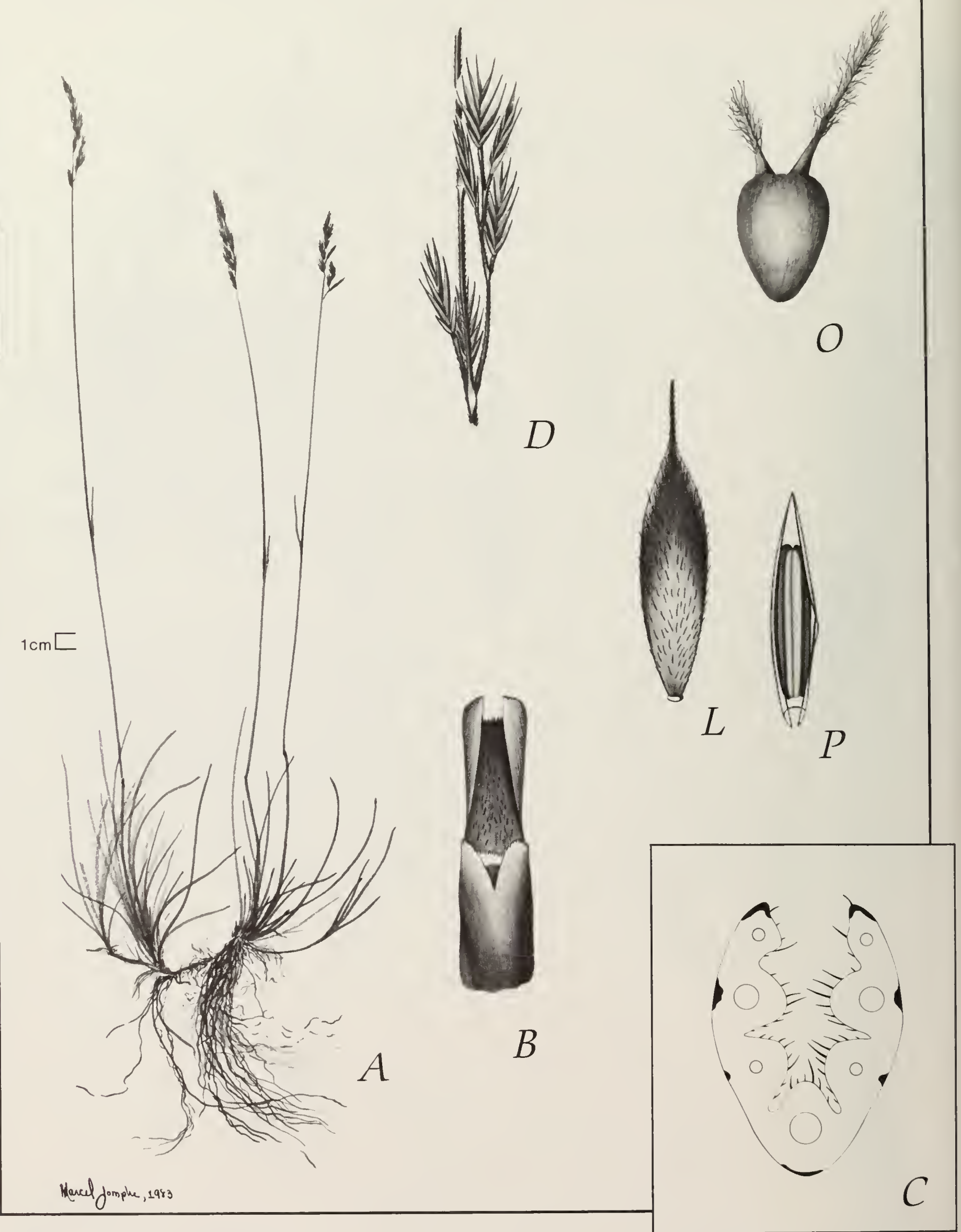

Plate 21 Festuca richardsonii. 


\section{Festuca richardsonii}

Festuca richardsonii Hooker, Fl. Bor.-Amer. 2:250. 1840.

F. rubra ssp. richardsonii (Hooker) Hultén, Fl. Alaska \& Yukon 2:246. 1942.

$F$. rubra ssp. arctica auct. non Govoruchin.

Plate 21, Map 16

Plants loosely caespitose, with some long rhizomes, often bluish green. Culms (7-)15$40(-50) \mathrm{cm}$ high; nodes exposed; internodes glabrous. New shoots extravaginal. Dead sheaths fibrillose. Living sheaths often reddish, closed to near top, with a prominent midvein; retrose trichomes usually present. Auricle positions rounded. Ligules erose, ciliolate, $0.05-0.4 \mathrm{~mm}$ long. Blades stiffish, usually plicate or occasionally flat, $3-23 \mathrm{~cm}$ long; blade of flag leaf (1.5-)2-4(-6) cm long. Anatomy of blade in cross section $0.5-1.1(-1.4) \times 0.7-$ $2 \mathrm{~mm}$; veins (5-)7(-9); ribs (3-)5-8, distinct; sclerenchyma in 3-8 strands distributed opposite some bundles and at blade margins.

Panicle (2-)3-5(-7) cm long, erect, narrow, usually very dense; branches of rachis one per node, short, 0.4-1.3 cm long, angular, with trichomes over entire surface, and with 1-3(-4) spikelets. Spikelets (6-)7-8 mm long, with 2-7 florets. Glumes glabrous to villous, unequal, shorter than spikelets; lower glume 1 vein, 1.5-3 $\mathrm{mm}$ long; upper glume 3 veins, 3-3.8 mm long. Lemmas scabrous to villous, with long white hairs (rarely glabrous), 5-6.5 mm long; awn 0.2-1.6 mm long. Paleas 4.5-6 mm long, with a few long trichomes between keels. Lodicules with one or more marginal teeth, without trichomes. Anthers more than half as long as paleas, (2.7-) 2.9-3.7 $\mathrm{mm}$ long. Ovary apex glabrous. $2 n=42$ Markgraf-Dannenberg (1980). Distribution outside Canada: Alaska.

\section{Discussion}

Hooker (1839-1840) recognized $F$. rubra as occurring in "Boreali-Americana" and stated that "in the more northern latitudes this species frequently becomes very hairy in its floscules [little flowers], and of a dark purplish colour," observations very suggestive of $F$. richardsonii. When Hooker described $F$. richardsonii, however, immediately after his comments on $F$. rubra he noted, " $F$. richardsonii] appears to be a very distinct species from any with which I am acquainted."

Hultén (1942) reduced the taxon to $F$. rubra ssp. richardsonii observing that northern specimens with very villose lemmas agree well with ssp. richardsonii, but specimens with glaucous lemmas occur, as well as intermediate forms, and these bridge the gap between the main types. Specimens collected from the south shore of Lake Athabasca, northern Saskatchewan have lemmas that range from very densely villose to glabrous. The latter have been referred to $F$. rubra ssp. richardsonii var. glabrata Hultén, but they have plumper spikelets than is usual in $F$. rubra. Specimens from the Yukon, when grown in Ottawa, retain their small stature. Löve and Löve (1956) cited reproductive incompatability and Pavlick (1985) cited morphological, habitat, and geographical differences to justify species status. 


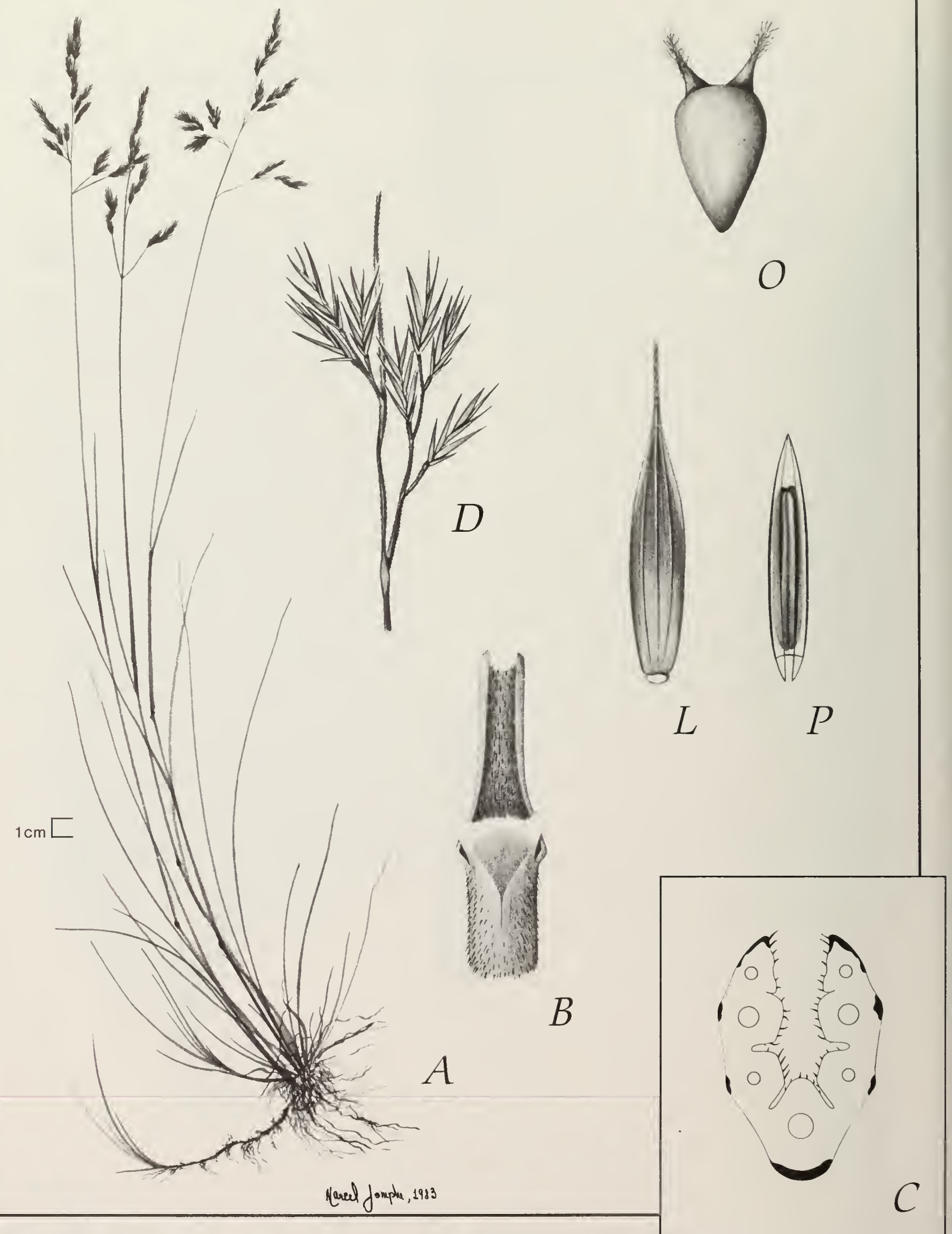

Plate 22 Festuca rubra. 
Festuca rubra

Festuca rubra L., Sp. Pl.:74. 1753.

(For extensive lists of synonomy see Hultén 1942, Tzvelev 1976, Alexeev 1985, Pavlick 1985.)

\author{
Red fescue \\ Plate 22, Map 17
}

Plants loosely tufted, decumbent, commonly with rhizomes. Culms 15-85 $(-120) \mathrm{cm}$ high; nodes exposed; internodes glabrous. Dead sheaths not prominent at base of plants, becoming fibrillose by splitting between veins. Shoots extravaginal. Living sheaths usually reddish, aging brown, closed for most of their length, glabrescent or rarely glabrous, rounded, usually with a prominent midvein, and usually pubescent with retrose trichomes. Auricle position with or without a distinct erect swelling. Ligule erose, higher on sides than in centre, $0.1-0.4 \mathrm{~mm}$ long; blades usually plicate, sometimes flat; basal leaves 5-30 cm long; abaxial epidermis glabrous, or scabrous near abruptly acute apex. Anatomy of blade in cross section $0.4-1.1 \times 0.7-2 \mathrm{~mm}$; large veins 3 ; smaller veins (2-)4; ribs (3-)5, prominent, usually sharp pointed; sclerenchyma in discrete strands opposite vascular bundles, commonly appearing as angular ridges in dried leaves.

Panicle open or somewhat compressed, erect or slightly nodding, (2-)7-14(-20) cm long; rachis branches scabrous, angular in cross section; spikelets 6-13 mm long, bright green or glaucous, rarely pruinose, with 2-10 florets. Glumes much shorter than spikelet, unequal, dorsally rounded or keeled, glabrous or with trichomes; margins erose; lower glume, (2-) 2.5-3.5(-4.5) mm long, 1(-3) veins; upper glume, 3.5-5(-6) $\mathrm{mm}$ long, 1.2-1.4(-1.6) $\mathrm{mm}$ wide, lanceolate, acuminate, (1-) 3 veins. Lemmas usually scabrous towards apex, elsewhere glabrous, 4-8 $\mathrm{mm}$ long; awn 0.3-3 mm long, less than one-half as long as lemma. Paleas, 4-7 $\mathrm{mm}$ long distinctly pubescent between keels. Lodicules with one or more marginal teeth, usually without trichomes. Anthers 2-3(-4.5) mm long, usually more than one-half length of paleas. Ovary apex glabrous.

$2 n=14,21,28,42,49,50,53,56,64,70$ (Bowden 1960, Taylor and Mulligan 1968, Dubé et al. 1985, Aiken et al. 1988).
Distribution outside Canada: Holarctic; introduced to many countries in the world. It is native in Canada in coastal areas and large inland lake and river systems such as the Great Lakes-St. Lawrence and those of the Northwest.

\section{Discussion}

The $F$. rubra complex includes a holarctic group that forms extravaginal shoots. With sheaths closed more than half their length, they turn dark brown and eventually only the vascular bundles persist as a loose fibrous tuft. Reproductively isolated forms occur and biological microspecies abound, but the continuity and plasticity of morphological characters make it a relatively coherent group. The modern taxonomy based on phylogeny and morphological discontinuity is often unsatisfatory in classification of complexes generated by selected breeding, hybridization, and wholesale introductions of aggressive species, such as $F$. rubra.

Dore and McNeill (1980) discussed seven variants in Ontario but did not formally recognize infraspecific taxa, stating "Festuca rubra includes a complex of native and introduced variants, the classification of which is not well understood." Dubé and Morisset (1987) presented a detailed study of morphological and leaf anatomical variation in $F$. rubra from eastern Quebec. Alexeev (1985) recognized ssp. aucta (Kreczetowicz \& Bobrov) Hultén, ssp. arctica (Hackel) Govoruchin (=F. richardsonii), ssp. pruinosa (Hackel) Piper, and $F$. prolifera (Piper ex Robinson) Fernald. The remaining variation he observed in Canadian material was referred to ssp. rubra. He also warned that many of the subspecific names originating in Europe have been misapplied by North American authors (Alexeev 1985). Markgraf-Dannenberg (1980) recognized seven subspecies among the European creeping red fescue complex and 
moved Chewing's fescue, well known as

$F$. rubra var. commutata Gaudin, to

$F$. nigrescens Lamark. Her treatment has been criticized as unworkable because supposed differences in spikelets between the subspecies are proving to be inconsistent, and because reproductive isolation is not complete (M.B. Forde, personal communication). Dubé et al. (1985) established that two chromosome races occur in Quebec; those with $2 n=42$ belong to $F$. rubra and those with $2 n=56$ have affinities with $F$. diffusa Dumort. The two ploidy levels are not always morphologically distinguishable. Pavlick (1985) provided a treatment for the complex in British Columbia where he recognized eight subspecies and two varieties.

A member of the $F$. rubra complex with very large spikelets and stiff, thick leaves occurs in coastal British Columbia, Alaska, and USSR. It has been given either species status as $F$. aucta Kreczetowicz \& Bobrov, or subspecies status as $F$. rubra ssp. aucta (Kreczetowicz \& Bobrov) Hultén, or has been placed in synonymy with $F$. rubra ssp. rubra as by Tzvelev (1976), who remarked that this highly polymorphic subspecies is divided into a series of inadequately studied races. The type of $F$. aucta (from the Komandor Islands) is a large specimen with partially flat blades up to $2.5 \mathrm{~mm}$ wide. Such well-developed specimens differ from other members of the red fescue complex in Canada, but specimens intermediate in appearance occur. In attempting to recognize subspecies within the complex following Markgraf-Dannenberg (1980) and Pavlick (1985), many problems were discovered and it is deemed currently inappropriate to adopt formal infraspecific classification for Canadian material.

Many cultivars of red fescue have been, and continue to be, developed for horticultural and agricultural purposes. Red fescue is considered one of the finest lawn grasses, especially for dry and partly shaded sites. Creeping red fescue is a valuable forage grass that is useful for pasture in many parts of Canada.

Unfortunately hay yields are generally poor. Boreal is a registered variety developed at Beaverlodge in 1966 and has one of the highest yields (Howe 1987). Although not sufficiently drought tolerant to be grown in the drier areas of the Prairie Provinces, it will tolerate more drying than other popular grasses such as timothy (Phleum pratense L.) and orchard grass (Dactylis glomerata L.). Palatability to livestock is only moderate but, because of its underground rhizomes and low growing habit, red fescue is able to withstand close grazing.

The proliferating form $(2 n=49,50$; Bowden 1960, Aiken et al. 1988), referred to by authors at various rankings, is a striking clonal form found in alpine and boreal habitats from New England to Newfoundland, Anticosti, Ungava, and the James Bay area. Other proliferating forms of the complex have been reported occasionally from other parts of Canada (e.g., Boivin 1981, Pavlick 1985). Taylor and Mulligan (1968) report a proliferating form, derived from $F$. rubra ssp. aucta (Pavlick 1985), from the Queen Charlotte Islands. This plant $(2 n=$ ca 70$)$ has been named $F$. rubra ssp. aucta forma pseudovivipara Pavlick, based on the proliferous spikelets and chromosome number. Extensive morphological variation in the $F$. rubra complex and the unknown functional mechanisms of proliferation prevent practical distinction of the clones that always produce plantlets from plants proliferating because of transient environmental conditions (Aiken et al. 1988). 



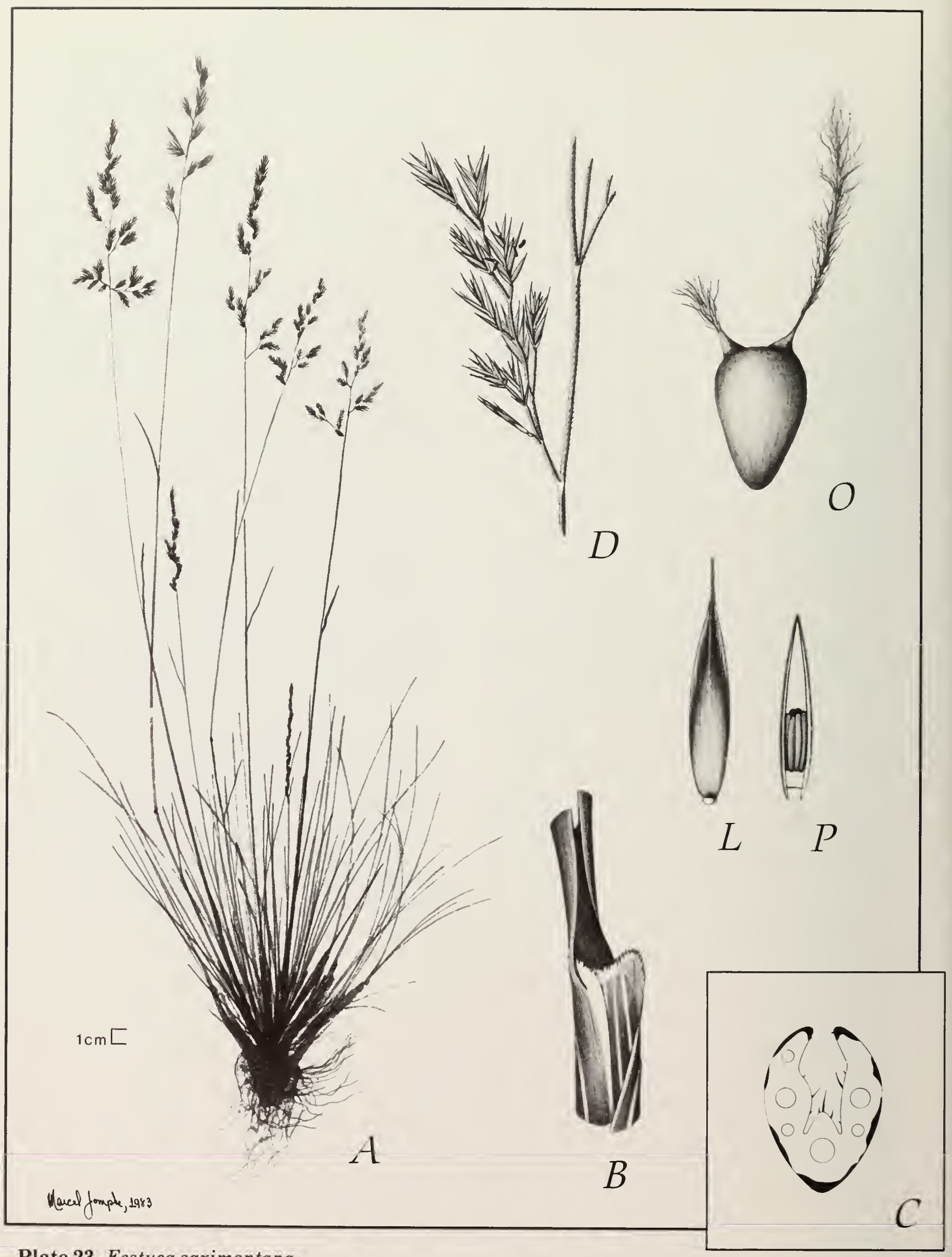

Plate 23 Festuca saximontana. 


\section{Festuca saximontana}

Festuca saximontana Rydberg, Bull. Torrey Bot. Club 36:536. 1909.

$F$. pseudovina auct. amer., non Hackel ex Wiesbaur.

F. ovina var. saximontana (Rydberg) Gleason, Phytologia 4:21. 1952.

$F$. ovina ssp. saximontana (Rydberg) Saint-Yves, Candollea 2:245. 1925.

F. brachyphylla ssp. saximontana (Rydberg) Hultén, Fl. Alaska \& Yukon 2:242. 1942.

F. purpusiana (Saint-Yves) Tzvelev, Zlaki SSSR:406. 1976.

F. canadensis Alexeev, Bull. Mosk. O-va Ispyt. Prir. Otd. Biol. 88:104. 1983.

\section{Rocky mountain fescue \\ Plate 23, Map 18}

Plants densely caespitose, without rhizomes, bluish grey to pale green. Culms (5-)20-40(-60) cm high; nodes sometimes exposed; internodes glabrous. Shoots intravaginal. Dead sheaths persisting at base of plant, not fibrillose. Living sheaths without conspicuous purple pigments, open almost to base, glabrous or with sparse minute retrose trichomes. Position of auricle with a distinct erect swelling. Ligule erose, $0.1-0.5 \mathrm{~mm}$ long. Blades slender, setaceous, stiffish, 2-15 $(-20) \mathrm{cm}$ long; abaxially glabrous or more usually with scabrous trichomes pointing towards leaf apex; blade of flag leaf $0.5-4 \mathrm{~cm}$ long. Anatomy of blade in cross section $0.3-0.7 \times 0.5-0.7 \mathrm{~mm}$, with 3 large and $0-5$ small veins; ribs 1 distinct and $0-2$ indistinct; sclerenchyma in broad bands to continuous along abaxial surface.

Panicle (1-)3-13 cm long; branches 0.5-3 $(-5) \mathrm{cm}$ long, erect or spreading at anthesis, angular in cross section, with trichomes on and between ridges. Spikelets (3-)4.5-8.8(-10) mm long, with (2-)3-7 florets. Glumes shorter than spikelet, unequal, scaberulous at apex, dorsally rounded or with a slight keel; margins erose; lower glume 1.5-3.5 mm long, 1 vein; upper glume $2.5-4.8 \mathrm{~mm}$ long, 3 veins. Lemmas 3-5.6 mm long, dorsally rounded, glabrous or scaberulous at apex; awn 0.4-2 mm long. Paleas 3-5 mm long, pubescent between keels at apex only. Lodicules toothed, without marginal trichomes. Anthers (0.8-) 1.2-1.7 $(-2) \mathrm{mm}$ long, one-third as long as paleas or less. Ovary apex glabrous.

$2 n=42$ (Bowden 1960).

Distribution outside Canada: Alaska, Pacific Ocean to the Great Lakes south to California.

\section{Discussion}

Rydberg (1909) described this species as, "rather common on dry hillsides and mountains from Saskatchewan to Colorado and British Columbia up to an altitude of $3600 \mathrm{~m}$." Porsild (1951) stated that it is common in the southeastern Yukon but that it is not encountered at or above the timberline. Frederiksen (1982) stated that " $F$. saximontana is a little more southerly than $F$. brachyphylla; it has not been found along the arctic coast and in most of the Canadian Archipelago."

Hultén reduced the taxon to

$F$. brachyphylla ssp. saximontana in 1942 , but in 1968 he recognized the two species $F$. brachyphylla and $F$. saximontana based on anther length. Frederiksen (1982) stressed that $F$. saximontana deviates from

$F$. brachyphylla and related taxa in having strongly developed sclerenchyma in the leaf blades and anthers normally longer than $1.2 \mathrm{~mm}$. Although the two species are normally quite distinct, some intermediate specimens are encountered. Particularly in northern areas of the range of $F$. saximontana such as the St. Elias Mountains (southwest Yukon Territory), James Bay (Ontario and Quebec), and Great Bear Lake (Northwest Territories), there is an over lap in anther size $(0.8-1.3 \mathrm{~mm})$ as well as leaf size and development of sclerenchyma tissue. (See also comments under $F$. brachyphylla.)

In discussing the difference in leaf sheaths between var. saximontana and var. purpusiana (Saint-Yves) Frederiksen \& Pavlick, Frederiksen (1982) stated, "according to my observations based on few specimens only, the sheath is never fused more than $1 / 3$ in 
var. saximontana, while it is about $1 / 2$ or more in var. purpusiana, as also stated by Tzvelev (1976)." Tzvelev (1976), however, recognized $F$. purpusiana (Saint-Yves) Tzvelev. Alexeev (1985) stated that in North America var. purpusiana is just an ecological response of $F$. saximontana where less sclerenchyma forms in the leaves and refers the Asian material of $F$. purpusiana sensu Tzvelev to $F$. brachyphylla. Some authors have emphasized the amount of sheath closure as a taxonomic character in separating the segregates var. saximontana, var. purpusiana, var. robertsiana Pavlick, and $F$. canadensis. In our experience, and that of others (e.g., Pils 1985), this feature is highly variable in most fescues. As previously discussed in comments relating to $F$. brachyphylla and $F$. idahoensis, culm height is known to be a phenotypically plastic character in $F$. saximontana. Data on herbarium labels and field observations suggest that taller plants of $F$. saximontana occur at lower elevations and in more-sheltered habitats, and that the development of purple coloration in spikelets in this taxon and others in the genus, is often associated with exposed alpine or arctic habitats but is variable even in these habitats. It is interesting to note, however, that a number of collections of var. purpusiana from subalpine and alpine habitats of southern Alberta and British Columbia retained their small stature and dense tufts under uniform cultivation in Ottawa. Variety robertsiana Pavlick, described from the Rocky Mountains of British Columbia, is intermediate in culm length between var. saximontana and var. purpusiana (Pavlick 1984) and is difficult to distinguish. 



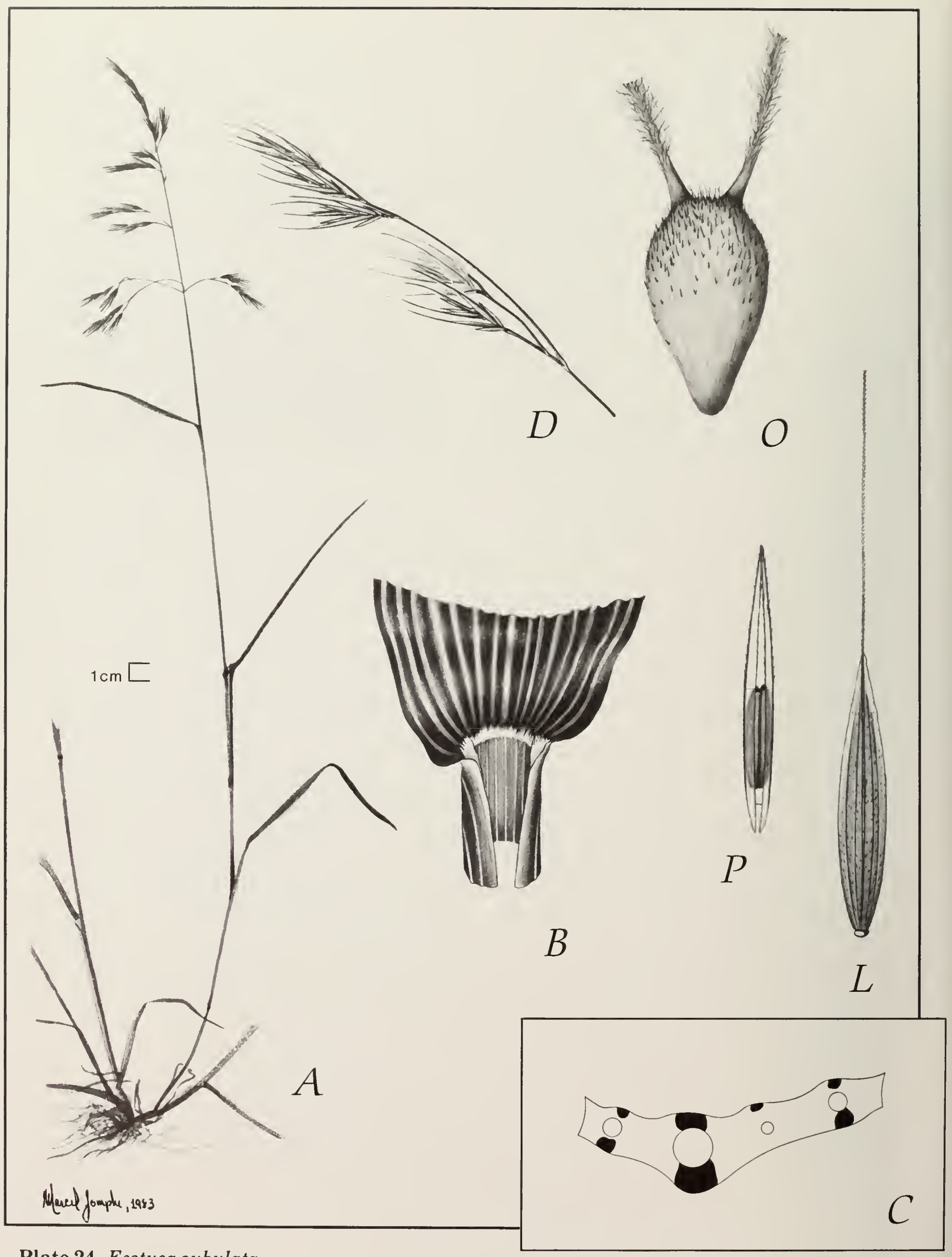

Plate 24 Festuca subulata. 


\section{Festuca subulata}

Festuca subulata Trinius in von Bongard, Mém. Acad. St. Petersb., sér. 6, Sci. Math. 2:173. 1832. F. jonesii Vasey, Contrib. U.S. Natl. Herb. 1:278. 1893.

\section{Bearded fescue \\ Plate 24, Map 19}

Plants loosely tufted, deep green. Culms leafy to near panicle, (38-)50-120 cm high, with 2-4 exposed nodes; internodes glabrous or scaberulous. Shoots extravaginal. Dead sheaths not prominent at base of plant. Living sheaths closed at least one-half their length, glabrous or glabrescent. Position of auricle rounded, glabrous. Ligule $0.2-1 \mathrm{~mm}$ long, erose, ciliate, with cilia much shorter than membranous portion. Blades flat, lax, 10-30 cm long, 3.5-10 mm wide; epidermi with or without scaberulous trichomes. Anatomy of blade in cross section with adaxial to abaxial girders; intercostal region between ribs more than twice the width of veins.

Panicle lax, (10-)15-30(-40) cm long, usually with 2 (rarely 1 or 3 ) main branches at lowest node; lower branches sometimes pulvinate at base, spreading, angular in cross section with trichomes over entire surface. Spikelets 6-11(-12) mm long, with (2-)3-5(-6) florets; rachilla scabrous, with internodes 1.5$2(-2.5) \mathrm{mm}$ long. Glumes narrowly lanceolate, unequal, both much shorter than first lemma, glabrous or scaberulous at apex only; margins usually erose; lower glume 1.8-4.0 mm long, 1 vein; upper glume (2-)3.5-5.5(-6) $\mathrm{mm}$ long, 3 veins. Callus short, glabrous. Lemma 5.0$7.5 \mathrm{~mm}$ long, usually with a slight keel, sparsely scaberulous over entire surface; awn straight, curving or kinking on drying, 5-8 $(-20) \mathrm{mm}$ long. Palea distinctly pubescent between keels. Lodicules with one or more marginal teeth, glabrous or with one or more marginal trichomes. Anthers 1.5-2.5(-3) mm long, lying one-third of the length of the palea or less. Ovary apex densely pubescent.

$2 n=28$ (Taylor and Mulligan 1968).

Distribution outside Canada: Southern Alaska south to California. In eastern Asia (Far East, USSR, nor theastern China, Korea, and Japan) a closely related taxon, referred to as $F$. extremiorientalis Ohwi ( $F$. subulata ssp. japonica (Hackel) Koyama \& Kawano), forms an amphipacific complex with $F$. subulata.

\section{Discussion}

Festuca subulata occurs in a wide variety of moist forests and edge habitats. Occasionally abundant growth can be seen in areas of recent clear-cutting. Anthesis occurs from May to July in British Columbia with more northerly populations flowering later. The population at Waterton Lakes, Alta., was observed from herbarium sheets to flower as late as August.

Piper (1906) did not examine the type of F. subulata but commented "the ample description accords so well with plants from near the type locality that there is scarcely room to question the identity of the species." He did examine the type of $F$. jonesii Vasey and claimed he could "find no characters by which $F$.jonesii can be kept distinct from $F$. subulata, even as a subspecies. The two type specimens are from almost the extremes of the range of the species. Contrasted with the Alaska specimens, the type of $F$. jonesii has slightly narrower leaves, and somewhat smaller spikelets, with its florets closer together, and the joints of the rachilla less scabrous. All manner of intergrades occur, however, and in such numbers that no satisfactory line of separation can be drawn."

Superficially this species may look like F. subuliflora, but Alexeev (1982) considered the two sufficiently distinct for him to place them in separate subgenera, Subulatae and Subuliflorae, respectively. Festuca subulata is distinguished by the wider leaves that are never more than merely scaberulous, the gently undulating blade surface resulting from the intercostal distance two to three times the width of the veins, the short ligule cilia, the nonstipitate florets, the unnotched lemma, and the straight rachilla. Although $F$. subuliflora has the common name crinkle awn fescue, the same character, of kinking in some awns, is also found in $F$. subulata. 


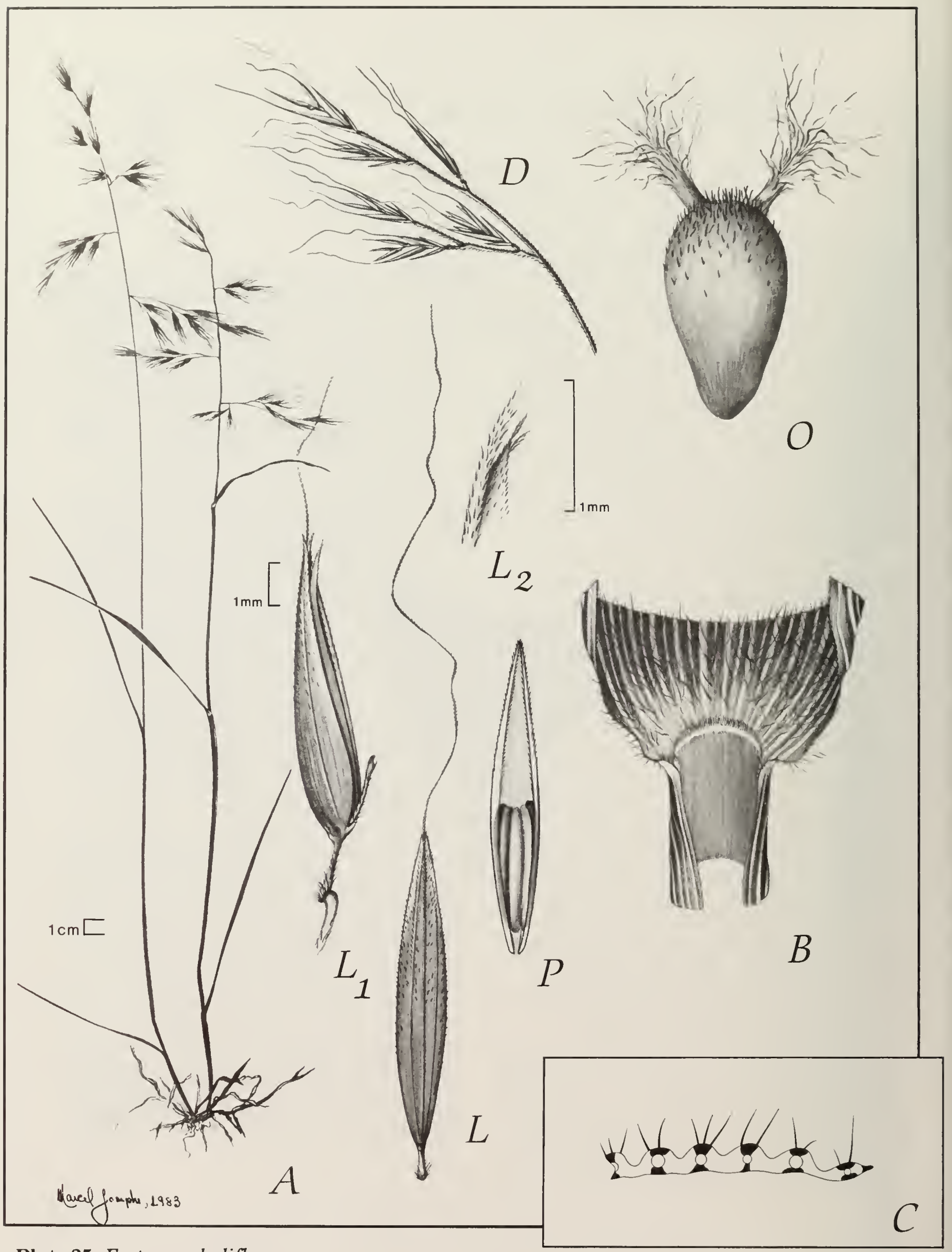

Plate 25 Festuca subuliflora. 


\section{Festuca subuliflora}

Festuca subuliflora Scribner in Macoun, Cat. Can. Pl. Add. \& Corr. I-IV 2(5):396. 1890.

F. ambigua Vasey, Contrib. U.S. Natl. Herb. 1:277. 1893.

F. denticulata Beal, Grasses N. Am. 2:589. 1896.

\section{Crinkle awn fescue \\ Plate 25, Map 20}

Plants deep green, loosely tufted, with or without short rhizomes or stolons. Culms (40-)55-80(-125) cm high, with 2-4 exposed nodes; basal leaves few; internodes glabrous. New shoots both in tra- and extra-vaginal. Dead sheaths not prominent at base of plant. Living sheaths with or without purple, glabrous, glabrescent or pubescent, closed at least half their length. Position of auricle rounded with no distinct swelling. Ligule ciliate, $0.1-0.5 \mathrm{~mm}$ long, with trichomes longer than membranous portion. Blades usually flat, lax, 10-20 cm long, 2-4(-6) $\mathrm{mm}$ wide (sometimes becoming plicate on drying); adaxial epidermis with dense trichomes over prominently ridged veins; abaxial epidermis with or without trichomes. Anatomy of blade in cross section with adaxial to abaxial girders, of sclerenchyma; intercostal distance $0.5-1.5$ $X$ the width of the veins.

Panicle open, flexuous, somewhat drooping, (7-)10-20 cm long; branches usually 1 or sometimes 2 at lowest node, some pulvinate, longest about half as long as panicle; branches rounded or angular in cross section, with trichomes over entire surface. Spikelets 8-12.5 mm long, with (2-)3-5 florets. Glumes much shorter than adjacent lemma, unequal, glabrous or scaberulous at apex only; margins erose, ciliolate; lower glume $2.5-4.0 \mathrm{~mm}$ long, 1 vein; upper glume (3.5-)4-6 mm long. Callus long, with a tuft of stiff trichomes basally. Lemma 6-8 mm long, scabrous over the whole surface, more so towards forked apex; veins distinct in dorsal view. Awn 10-15 mm long, flexuous, often recurved or crinkled. Palea distinctly pubescent between keels. Lodicules with one or more marginal teeth and trichomes. Anthers 2-3 mm long, top of anther lying about one-third of palea length or less. Ovary apex densely pubescent.

$2 n=28$ (Hitchcock et al. 1969).

Distribution outside Canada: Washington to northwestern California.

\section{Discussion}

A woodland grass of heavily shaded forests, often in spots of sunlight, $F$. subuliflora occurs in shallowly rooted, loose tufts in rich loamy duff. In British Columbia it is restricted to the Douglas-fir forests of southeastern Vancouver Island, with one old collection from the Vancouver area.

Macoun (1890) quoted a letter from Scribner giving the characters used to distinguish $F$. subuliflora from $F$. subulata; "Note that the branches of the rather short panicle are all solitary, that the curved callus of the following glume [lemma] is remarkably long and is covered with a few short stiff hairs, that the edges of the flowering glume are ciliate with a few scattered hairs near the base, and that the joints of the rachilla are ciliatescabrous. The panicle branches are shorter than in your No. 89 [F. subulata in Macoun 1890], the leaves are shorter, of much firmer texture and pubescent on the upper surface."

Piper (1906) commented that this is "a very remarkable species, possessing a form of lemma peculiar to itself. The stipitate base of the lemma might better be considered a downward elongation of the callus, surrounding and becoming grown to the rachilla, which has likewise become elongated so that the joint is still at the base of the callus." 


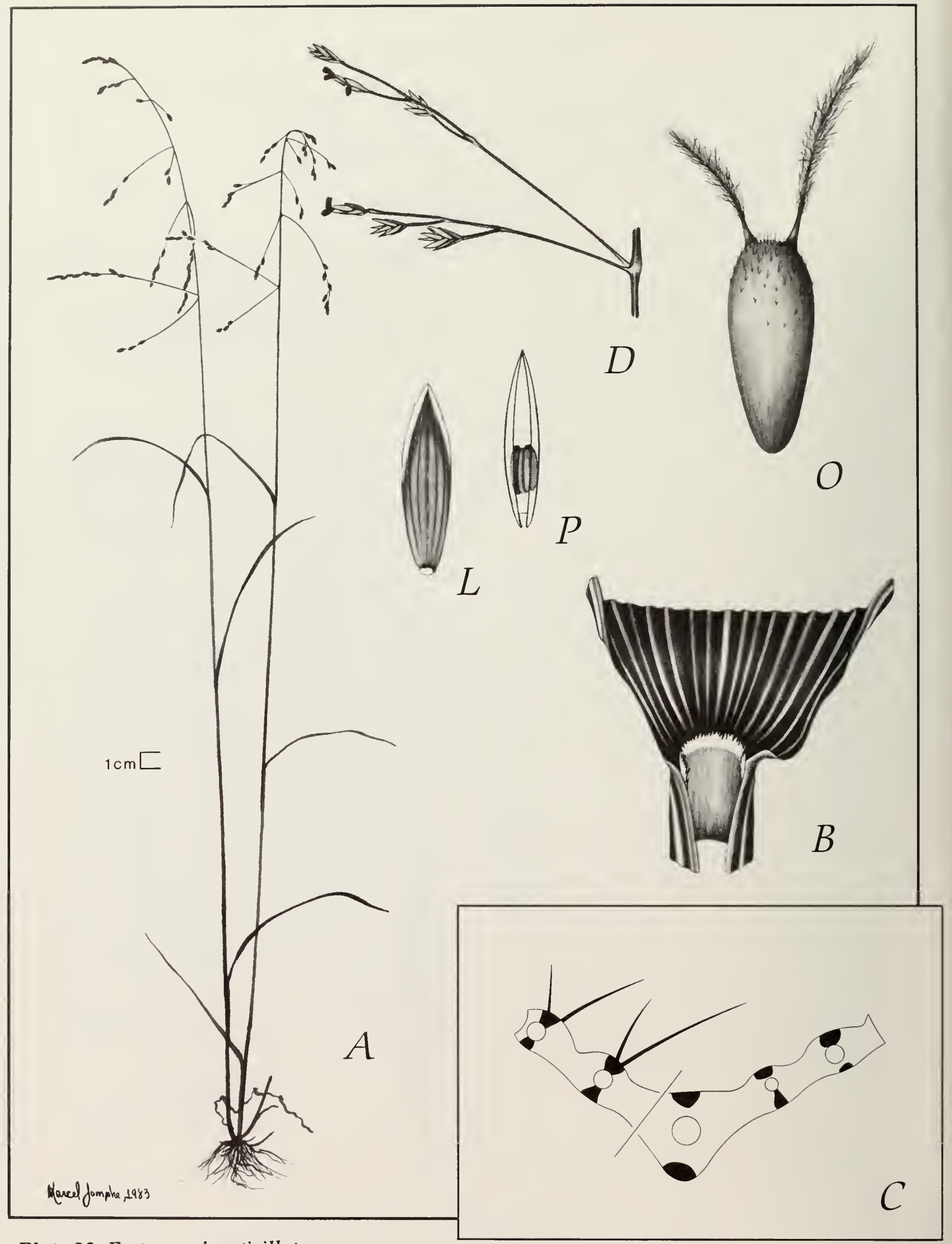

Plate 26 Festuca subverticillata. 


\section{Festuca subverticillata}

Festuca subverticillata (Persoon) E. Alexeev, Nov. Syst. Vyssh. Rast. 17:52. 1980.

$F$. nutans auct. non Moench, nec Biehler, nec Host.

F. obtusa Biehler, Pl. Nov. Herb. Spreng. Cent.:11. 1807.

Nodding fescue

Plate 26, Map 21

Plants tufted, without rhizomes, deep green. Culms 50-100(-130) cm high; nodes exposed; internodes glabrous. Shoots intravaginal. Sheaths open to near base, rounded, glabrous, glabrescent, or with long retrose trichomes; on dying, sheaths sometimes splitting between veins but not becoming fibrilose. Position of auricle with or without a distinct erect swelling. Ligule $0.3-0.1 \mathrm{~mm}$ long, sparsely erose. Blades convolute in bud becoming flat and lax, 4-10 mm wide; adaxial epidermis glabrous or with long trichomes; abaxial epidermis glabrous, undulating over veins with intercostal zone $2-3$ times the width of veins. Anatomy of blade in cross section with adaxial to abaxial girders of sclerenchyma.

Panicle open, 13-25 cm long; branches to $14 \mathrm{~cm}$ long with 3 acute angles and trichomes on or between angles. Spikelets green, 4-5 mm long, with 2-4(-6) florets. Glumes much shorter than spikelets, unequal, dorsally rounded and sometimes with a prominent midvein; trichomes only at apex of midvein, elsewhere glabrous; margins sometimes erose; lower glume 2-3 $\mathrm{mm}$ long, with 1 vein; upper glume, 2.5-4 mm long, with 3 veins. Lemma broadly rounded, dorsally glabrous, $3.2-4.5 \mathrm{~mm}$ long, subcoriaceous. Paleas strongly concave when mature and glabrous between veins. Lodicules toothed, without marginal trichomes. Anthers 1.1-1.6 mm long, one-third or less the length of palea. Ovary apex distinctly hairy. $2 n=42$ (Bowden 1960).

Distribution outside Canada: South to Mexico.

\section{Discussion}

Festuca subverticillata, previously known as $F$. obtusa, is a common woodland grass found under a wide variety of forest types. In moist habitats, such as deciduous or coniferous swamps, the growth is tall and lax. Culms may be 1-1.3 $\mathrm{m}$ high and are often somewhat decumbent at the base. Sometimes on very wet substrates the decumbent base of the culm begins rooting at the nodes and appears to have short stolons. The leaves are flat and lax, and the panicle branches are reflexed arching gracefully in a broad curve. The branches at each node are somewhat secund and are separated by angles of 30-50 degrees. On drier sites the culms are shorter, thinner, and more or less erect in loose tufts, and the leaves are shorter and stiffer and are usually slightly involute. When growing in the open such as in a moist field at the edge of a forest, the foliage often becomes streaked and blotched with purple pigments and the leaves are stiffer and shorter than plants growing in shaded sites. The spikelets have not been observed to develop purple pigments, even when the foliage appears a diffuse reddish color. Plants in which the sheaths and blades have long, but sparse, pilose trichomes have been named $F$. obtusa forma pilosifolia Dore. 

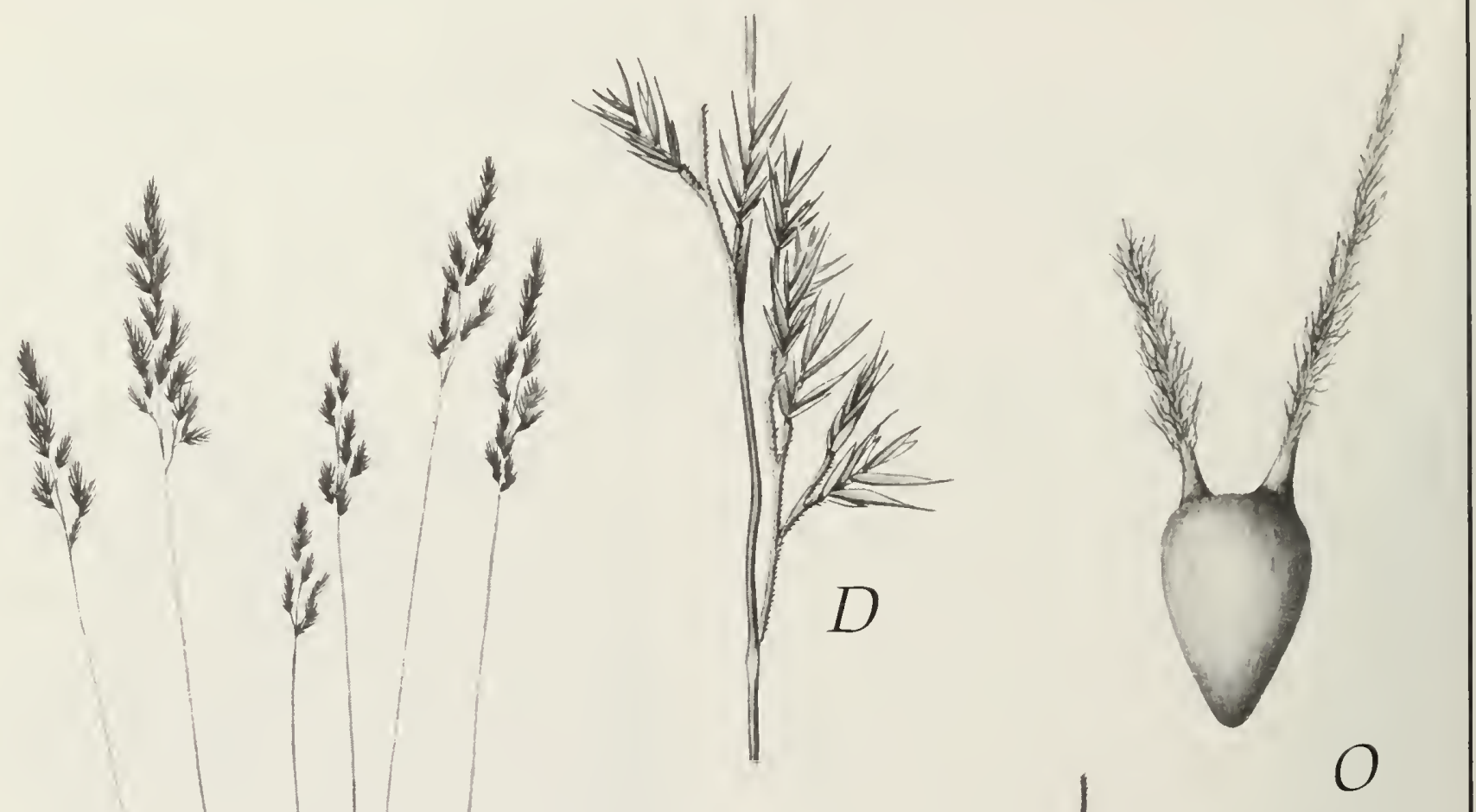


\title{
Festuca trachyphylla
}

\author{
Festuca trachyphylla (Hackel) Krajina, Acta Bot. Bohem. 9:191. 1930. \\ $F$. duriuscula auct. non L. \\ F. ovina var. duriuscula auct. \\ F. longifolia Thuillier, Fl. Paris ed. 2:50. 1799. \\ F. brevipila Tracey, Pl. Syst. Evol. 128:287. 1977.
}

\section{Hard fescue, hard sheep fescue \\ Plate 27, Map 22}

Plants coarse, densely tufted, green to bluegreen or glaucous, without rhizomes. Culms 20-60(-75) cm high; nodes exposed; internodes glabrous or with sparse trichomes. Shoots intravaginal. Dead sheaths not fibrillose, remaining firm at base of plant. Living sheaths open to base, with or more usually without purple pigments, rounded with a more or less prominent midvein, glabrescent. Auricle position with a distinct erect swelling. Ligule erose, $0.2-$ $0.5 \mathrm{~mm}$ long. Blades setaceous, rarely flat, coarse, glabrous, scabrous or puberulent. Anatomy of blade in cross section 0.4-0.6 $\times$ 0.7-1.15 mm; veins $5-7 ; 3-5$ well-defined ribs; sclerenchyma unevenly thickened, continuous or interrupted around abaxial surface.

Panicle narrow, 3-9(-13) cm long, dense or lax; branches to $3.5 \mathrm{~cm}$ long, usually less, angular in cross section, scabrous on angles. Spikelets yellow-green, blue-green, or purple, 5.5-9.0 $\mathrm{mm}$ long; rachilla commonly visible between 3-7(-8) florets. Glumes much shorter than spikelets, unequal, dorsally rounded, glabrous, or scaberulous only at apex, or with trichomes over entire surface; margins erose; lower glume 2.0-3.5 mm long, 1 vein; upper glume 3.0-5.5 mm long, 3 veins. Lemmas 3.8$5 \mathrm{~mm}$ long, dorsally rounded, either glabrous, apically scaberulous, with a fringe of hairs at apex margins or densely hirsute; awn $0.5-$ $2.5 \mathrm{~mm}$ long. Paleas 3.8-5 mm long, pubescent between keels. Lodicules with one or more marginal teeth, without trichomes. Anthers half or more than half the length of paleas, (2.3-)2.5-3 mm long. Apex of ovary glabrous. $2 n=28,42$ (Alexeev 1972).

Distribution outside Canada: Introduced and naturalized throughout many temperate countries; native to Eurasia.

\section{Discussion}

McNeill and Dore (1977) discussed this species under the name $F$. longifolia and explained that, although it is definitely related to $F$. ovina, the type of $F$. duriuscula L. is a member of the F. rubra group and so the epithet cannot be applied in this sense. While they were aware that Tzvelev (1972b) had adopted the name $F$. trachyphylla they referred to other European authors Auquier (1973) and Kerguélen (1975), who retained the name $F$. longifolia for at least part of $F$. duriuscula auct. Markgraf-Dannenberg (1980) followed Tzvelev $(1972 b, 1976)$ and adopted the name $F$. trachyphylla for hexaploid plants of the complex. Kerguélen (personal communication) examined plants of the complex growing in Ottawa and annotated plants collected in Quebec as F. trachyphylla commenting that, in Europe, this species is sold as "hard fescue" and that many cultivars are seeded because of their resistance to frost and drought. Festuca longifolia, however, is a more delicate, diploid species with limited distribution on sandy, acidic soils in coastal western Europe, southern Britain, and northwestern and central France. Its glabrous leaves are always pruinose and the anatomy of the leaf blade in cross section shows continuous marginal sclerenchyma and flattened ribs.

Alexeev (1975) described $F$. trachyphylla as an anthropogenic, introgressive, hybrid species ( $F$. valesiaca Schleicher ex Gaudin $\times F$. ovina). The species developed in relatively recent times, successfully invading habitats disturbed by human activity in central Europe. Vigorous establishment in early successional habitats was undoubtedly a character recognized as valuable in its early selection as a turf and pasture plant. Through commercial seeding and naturalization, the distribution of $F$. trachyphylla now extends into most of Europe as well as North America.

Markgraf-Dannenberg (1980) described the leaves of this species as strongly scabrid throughout, sometimes tomentose below, but most of the plants examined from Canada have leaves with the abaxial surface glabrous, though pubescent forms do occur separately and even on the same plant. It is known to be a highly variable species. 


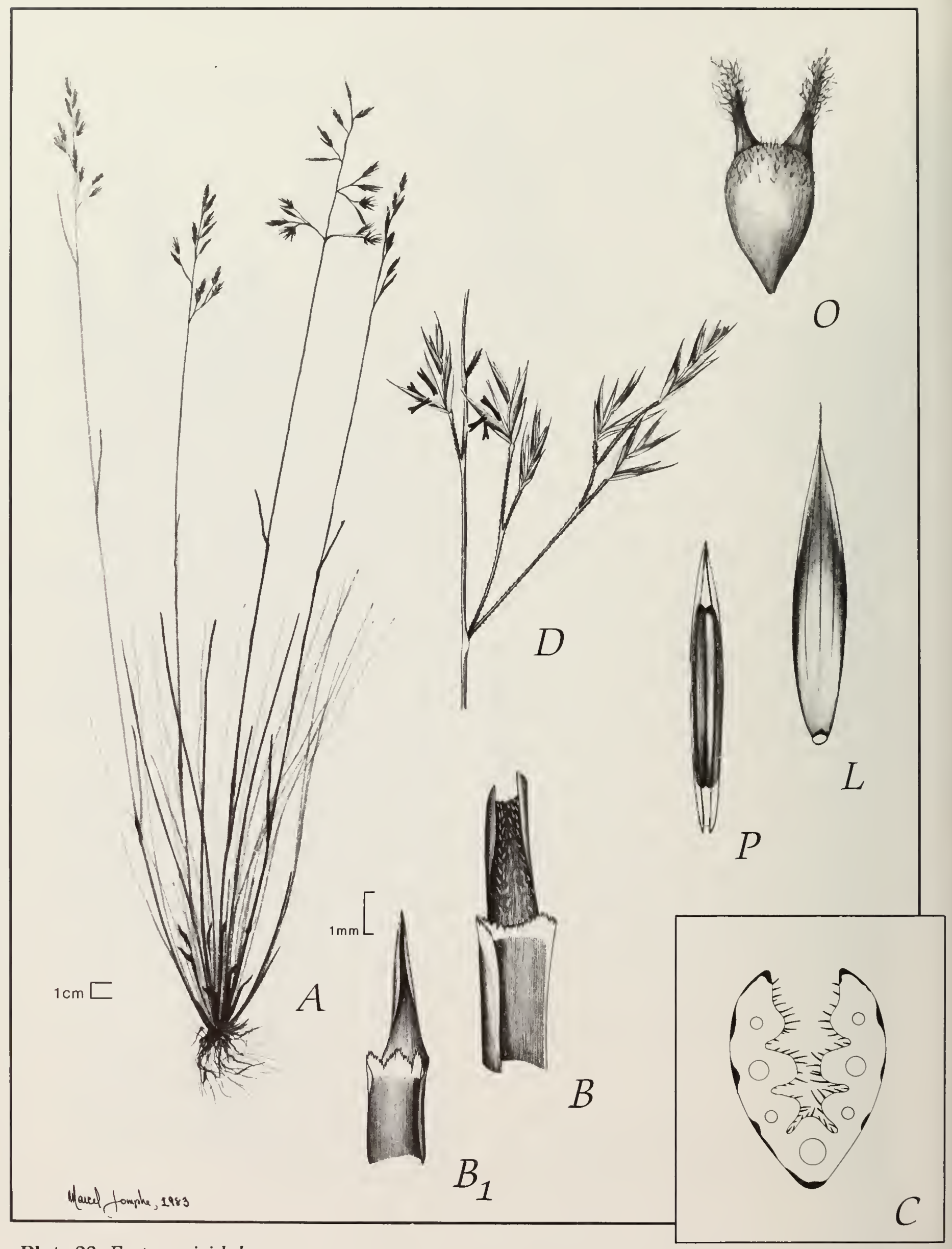

Plate 28 Festuca viridula. 


\section{Festuca viridula}

Festuca viridula Vasey, U.S. Dep. Agric. Div. Bot. Bull. 13:pl. 93. 1893.

F. howellii Hackel in Beal, Grasses N. Am. 2:591. 1896.

\section{Green fescue, green-leaf fescue, mountain bunch grass Plate 28, Map 23}

Plants densely to loosely tufted from a coarse base, forming small clumps from short rhizomes. Culms 35-80(-90) cm high; nodes exposed; internodes glabrous. Shoots intra and extravaginal. Dead sheaths not prominent at base of plant, splitting into long fibers but not becoming distinctly fibrillose. Living sheaths with or without purple pigments, open or closed for less than one-quarter of their length, rounded, glabrous to pubescent. Position of a uricle with a distinct erect swelling. Ligules erose, $0.2-0.5 \mathrm{~mm}$ long. Blades lax, or drying stiffish, plicate or flat, $0.8-2.0(-2.5) \mathrm{mm}$ wide; adaxial epidermis puberulent, scaberulous; abaxial epidermis glabrous. Anatomy of blade in cross section $0.4-0.9 \times 0.6-1.0 \mathrm{~mm}$, veins 3-5 large, 4-7 small; ribs 6-9; sclerenchyna in strands in slender discrete bundles opposite vascular bundles.

Panicle open or somewhat contracted, 4-12(-15) cm long. Spikelets 9-12 $\mathrm{mm}$ long, with (2-)3-5 florets. Glumes unequal, much shorter than spikelet, keeled, scaberulous at apex only; margins erose; lower glume (2.5-)2.8-4.5 mm long, 1 vein; upper glume 4.5$6.0(-8.5) \mathrm{mm}$ long, (1-) 3 veins. Lemmas 4.8$8.5 \mathrm{~mm}$ long, keeled at least towards apex, often green at base, with purple towards tip, glabrous everywhere or scaberulous only at apex; awnless or with an arista $0.2-0.5$ $(-1.4) \mathrm{mm}$ long. Palea 5.0-8.2 $\mathrm{mm}$ long, usually pubescent between keels. Lodicules toothed, with or without trichomes. Anthers 2.5-4.0 $(-5.0) \mathrm{mm}$ long, more than half as long as palea. Apex of ovary densely pubescent. $2 n=28$ (Myers 1947).

Distribution outside Canada: Washington to Montana, south to California east of the Cascade Mountains. Reported occurrence in Alberta is discussed by Boivin (1981), but neither he nor the present authors have been able to confirm these reports.

\section{Discussion}

Pavlick (1983c) documented confusion over the lectotype of this species explaining that Vasey's (1893a) selection was correct and that Piper (1906) misinter preted the protologue in Vasey (1893b). Piper's selection of a Bolander California specimen was followed by Hitchcock and Chase (1951).

Green fescue is an important alpine and subalpine forage in the Rocky Mountains of the United States. Its importance as forage in Canada is minor because of its limited distribution. 


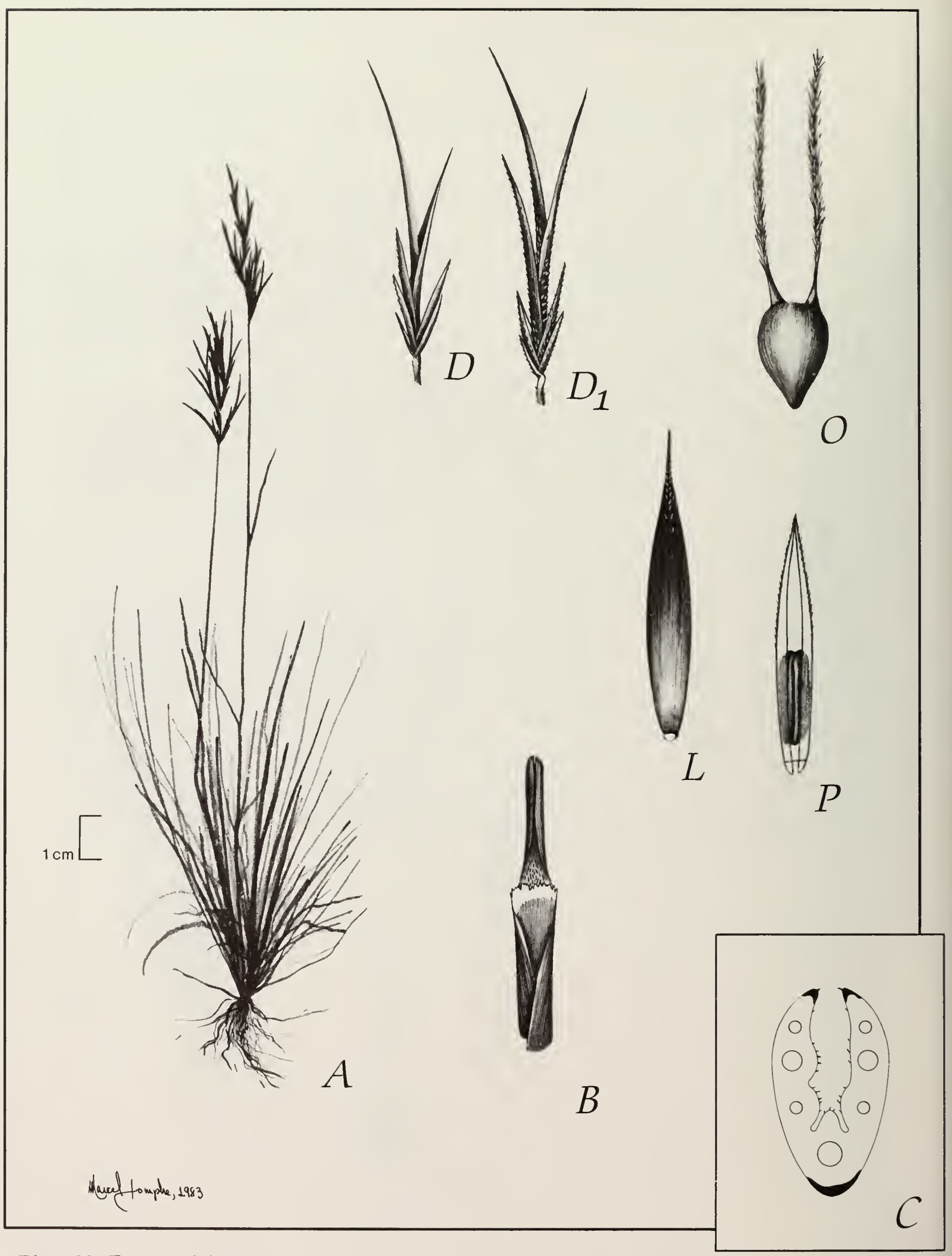

Plate 29 Festuca vivipara. 


\title{
Festuca vivipara
}

\author{
Festuca vivipara (L.) Smith, Fl. Brit. 1:114. 1800. \\ F. ovina var. vivipara L., Sp. Pl. ed. 2:108. 1762. \\ F. viviparoidea Krajina ex Pavlick, Can. J. Bot. 62:2454. 1984. \\ F. frederikseniae Alexeev, Novst. Sist Vyssh. Rast. 22:28. 1985.
}

\section{Plate 29; Maps 24, 25}

Plants densely tufted, without rhizomes, bluish or grey green. Culms (5-)10-35(-43) cm high; nodes usually exposed; internodes glabrous or sparsely puberulent. Shoots intravaginal. Dead sheaths persisting, not splitting into fibers. Living sheaths without, or with slight purple pigmentation, open for half their length (vegetatively proliferating plants of $F$. vivipara $\times F$. rubra have closed sheaths), glabrous or glabrescent; midvein prominent. Position of auricle with or without a distinct swelling. Ligule $0.2-0.5 \mathrm{~mm}$ long, higher at sides, distinctly erose. Blade stiffish, setaceous; blade of flag leaf $0.5-2.5(-5) \mathrm{cm}$ long. Anatomy of leaf in cross section, $0.25-0.6 \times 0.5-0.9 \mathrm{~mm}$, with sclerenchyma in 3 large and 0-4 small bundles; ribs 1-4; adaxial sclerenchyma from poorly developed along $10 \%$ of outer margin to a more-or-less continuous subepidermal band.

Panicle compact, 2-8 cm long; branches short, erect, scabrous. Spikelets often purplish, $0.7-3.5 \mathrm{~cm}$ long (varying with extent of vegetative proliferation). Glumes and commonly 1 or 2 adjacent florets normally developed; glumes much shorter than spikelet, unequal, rounded on the back; margins erose; lower glume 2.0-4.5 mm long, 1 vein; upper glume 3.8-5.2 mm long, 3 veins. Lemmas almost glabrous to hirsute, varying from short and awned (like $F$. trachyphylla) to awnless and leaflike in structure with ligule. Paleas usually absent or reduced. Lodicules toothed when present, without trichomes. Anthers rarely present, to about $2 \mathrm{~mm}$ long; pollen mostly sterile. Apex of ovary glabrous. $2 n=28,49,56,63$ (Frederiksen 1981). Many other counts have also been reported under the name $F$. vivipara, including $2 n=21,35$, and 42.

Distribution outside Canada: Holarctic.

\section{Discussion}

The name $F$. vivipara has been applied by authors in various ways. For example, Hitchcock and Chase (1951), Boivin (1967), and Scoggan (1978) applied it to any fescue of the ovina group with proliferating spikelets. Other authors, including Frederiksen (1981), Pavlick (1984), and Alexeev (1984, 1985), recognized and named various entities at subspecific or specific ranks. Frederiksen (1981) and Alexeev (1985) recognized two taxa, $F$. vivipara $\mathrm{ssp}$. glabra Frederiksen ( $F$. viviparoidea Krajina ex Pavlick sensu Alexeev) and $F$. vivipara ssp. hirsuta (Scholander in Devold \& Scholander) Frederiksen $(F$. frederikseniae Alexeev). The former taxon is holarctic and is present in Canada on Ellesmere Island and alpine habitats of the western cordillera. The latter taxon is found from the northwestern Atlantic area in southern Greenland, western Newfoundland, eastern Quebec, and southeastern Labrador. Pavlick (1984) further recognized two entities within $F$. viviparoidea. The typical subspecies, ssp. viviparoidea, is circumpolar with Canadian collections only from Ellesmere Island. The form found in alpine sites in the western cordillera (Alberta, British Columbia, Yukon, and the Northwest Territories) is referred to ssp. krajinae Pavlick. Festuca vivipara ssp. vivipara is an old-world taxon not known from North America except eastern Greenland.

The diversity of morphological form and chromosome number indicate a polyphyletic origin for $F$. vivipara (sensu amplissima). Several authors have suggested that the viviparous $F$ estuca may be species complexes of hybrid origin that have become stabilized by means of vivipary (Flovik 1938, Löve and Löve 1956, Tzvelev 1972b, Siplivinskii 1973, 
Frederiksen 1981, Pavlick 1984). Pavlick (1984) speculated on the hybrid origin, $F$. brachyphylla $\times F$. baffinensis, for ssp. glabra (F. viviparoidea). Siplivinskii (1973) stated that plants in which the features of vivipary and a continuous band of sclerenchyma are combined should be considered to have resulted from hybridization of viviparous fescues with $F$. ovina sensu lato. Although an almost continuous band of sclerenchyma is found in some specimens of $F$. vivipara ssp. hirsuta, the sclerenchyma in $F$. vivipara ssp. glabra is in well-separated strands, mainly at the midrib and blade margins (Frederiksen 1981, Pavlick 1984, Aiken et al. 1985).

Taxonomic classification is always problematical among essentially clonal organisms. Having summarized the differing opinions and problems, the present authors prefer the broader species concepts for this entity, which recognizes the various types as subspecific taxa. Also to be noted is the confusing nature of facultative, ephemeral, vegetative proliferation that can be environmentally induced in fescues under adverse conditions (see section on Vegetative proliferation or pseudovivipary). Identification of this condition on herbarium sheets can be virtually impossible (compare Aiken et al. 1988).

Another complicating factor is the occasional production of viable gametes in $F$. vivipara that allows hybridization with members of the $F$. ovina and $F$. rubra complexes. Frederiksen (1981) reported that the hybrids between $F$. rubra and either
$F$. vivipara ssp. vivipara or ssp. hirsuta are highly variable but can usually be identified by the presence of a number of characters in common with $F$. rubra, including the larger size of the plants, extravaginal shoots, entire sheaths, and the leaf blade anatomy. These plants have been named $F$. $\times$ villosa-vivipara (Rosenvinge) Alexeev. Löve and Löve (1956) report $2 n=35$ for these hybrids in Iceland. They are usually collected in areas where $F$. vivipara sensu stricto does not seems to occur (Porsild 1966).

In "viviparous" species of Festuca the spikelets are conspicuously modified into bulbils that weigh 10 times as much as seeds of $F$. ovina (Jenkin 1922; Wycherley 1953a, b; Harmer and Lee 1978). Normally, adventitious roots are formed in the lower part of the bulbil before it is shed. Under favorable conditions, new plants develop quickly from the bulbils. The weight of bulbils, and their inability to withstand drought, has been thought to indicate that they are not adapted for longdistance dispersal (Frederiksen 1981). Elven (1980) and Heide (1988), working in Norway, suggested that the bulbils are well adapted for dispersal and become established even under conditions prevailing in the proximity of glaciers. These workers observed that bulbils are moved by wind for substantial distances across smooth surfaces of packed snow, ice, or rocks and that they have been known to pass ice barriers of several kilometres. The desiccating effects of high-velocity, arctic and alpine winds, however, would likely limit the viability of bulbils exposed for long periods. 


\section{Key to F. vivipara complex in Canada (after Frederiksen 1981 and Paulick 1984)}

1 Culm internodes puberulent, at least near the inflorescence. Position of auricle with a distinct erect swelling. Branches of rachis densely pubescent over entire surface. Glumes and lemmas densely hirsute over entire surface. $2 n=28$.

Newfoundland, Labrador, and southern Greenland .... ssp. hirsuta

1 Culm internodes glabrous to puberulent. Position of auricle rounded or with an indistinct swelling. Branches of rachis usually with trichomes mainly on angles. Glumes and lemmas glabrous, sparsely scabrous or scabrid towards the apex. $2 n=49$, 56,63. High Arctic and Rocky Mountains .... (ssp.glabra) ... 2

2 Plants densely caespitose. Leaf sheaths stramineous.

Leaves in cross section with wide bands of sclerenchyma; width of bands $>2 \times$ to $<3 \times$ depth. Culms immediately below inflorescence densely to sparsely puberulent. Glumes and lemmas glabrous to scabrid at apices ........... viviparoidea ssp. viviparoidea

2 Plants more or less loosely caespitose. Leaf sheaths brownish, often splitting into fibers. Leaves in cross section with narrow bands of sclerenchyma; width of bands $<2 \times$ depth. Culms immediately below inflorescence usually glabrous, sometimes sparsely puberulent. Glumes and lemmas scabrous to scabrous apically .................... viviparoideassp. krajinae 


\section{Concluding remarks}

Although all species in the genus Festuca have spikelets like those of the hypothetical, primitive grass, many show considerable adaptation in vegetative growth form, breeding systems, and physiology. Some economically important species have been planted widely around the world, whereas many others occur in specialized habitats in temperate, boreal, and polar regions of both hemispheres. While overall morphological differences are slight and discontinuities sometimes vague, the genus is rich in subtle degrees of variation that, in some sections, tend to resist satisfactory

classification.

In this treatment we have recognized 24 species of Festuca as occurring in Canada. Most of the major decisions on the taxonomy used were taken before 1984. New information is continually being made available, and, in the future, finer resolution of taxa or reevaluation of the ranking of presently recognized taxa may be warranted. Some taxa have been more or less consistently recognized; those native to Canada include $F$. altaica sensu stricto, $F$. occidentalis, $F$. subulata, $F$. subuliflora, $F$. subverticillata ( $F$.obtusa), and $F$. viridula. Three species complexes, representing a number of important economic species will require further study.

\section{The rough fescue complex We have} followed the treatment of Pavlick and Looman (1984) and recognized three species among the Canadian rough fescue complex: $F$. altaica, $F$. campestris, and $F$. hallii. Few morphological characters separate these three and more research may provide a better understanding of the group.

\section{The sheep fescue complex Seven of the 24} species that we recognize are closely related arctic or alpine members of this complex, namely $F$. baffinensis, $F$. brachyphylla, $F$. brevissima, $F$. hyperborea, $F$. lenensis, $F$. minutiflora, and $F$. vivipara. The occurrence of $F$. hyperborea in Canada has been extensively documented from field experience and many herbarium specimens. Festuca brevissima and $F$. lenensis are now recognized a Beringian species that occur in northwestern Canada and Alaska. Many good collections of $F$. lenensis now exist, but $F$. brevissima, especially in Canada, is undercollected. Following the treatment of Frederiksen (1982), we recognize $F$. vivipara ssp. glabra and ssp hirsuta in Canada, but these taxa still need more study to be fully understood. The previously overlooked $F$. minutiflora is a distinct Cordilleran taxon that has been collected in Alberta, British Columbia, and the Yukon.

Among the sheep fescues that grow in southern Canada are the native taxa $F$. occidentalis, $F$. idahoensis, $F$. saximontana, and $F$. viridula and the introduced Eurasian species $F$. filiformis and $F$. trachyphylla. Throughout its range in North America the $F$. idahoensis complex is rather variable. More study is needed to decide whether to recognize further species or infrataxa and if intergradation with other species occurs.

Festuca saximontana is treated as specifically distinct from $F$. brachyphylla following current treatments. Occasionally these two taxa are difficult to distinguish. Festuca brachyphylla may be hybridizing with $F$. saximontana, or clinal variation may be involved.

The red fescue complex Aiken et al. (1988) suggested that the phenomenon of vegetative proliferation in this complex should not be given taxonomic status; but they now accept that it may be convenient to recognize specimens with proliferating spikelets as a forma. Festuca richardsonii is treated as a species distinct from $F$. rubra with some reservations. Although the period 1970-1990 has seen much resolution in the $F$. ovina complex, little progress has been made in resolving taxonomic problems among the red fescues. 


\section{Collection sites}

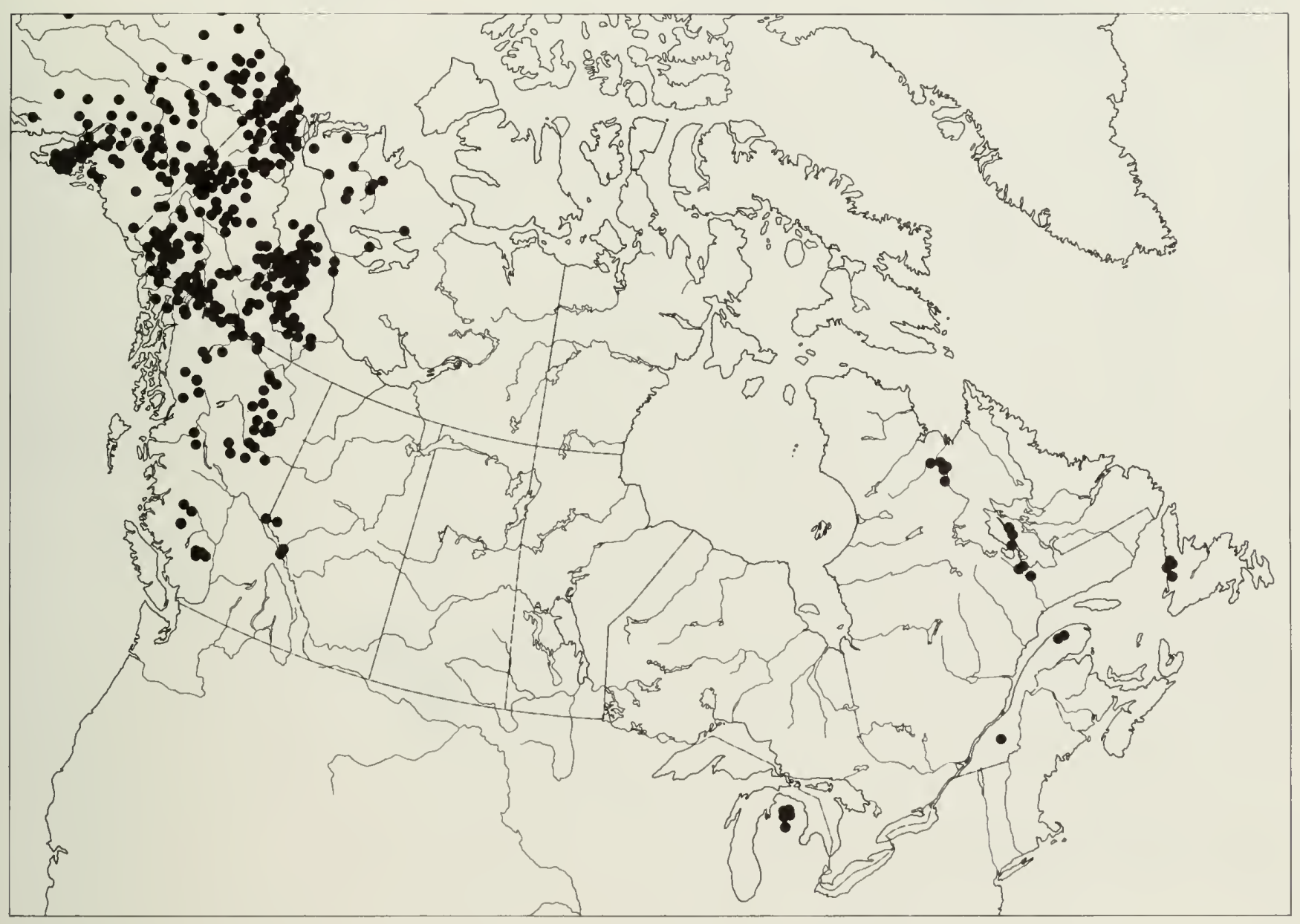

Map 1 Festuca altaica. 


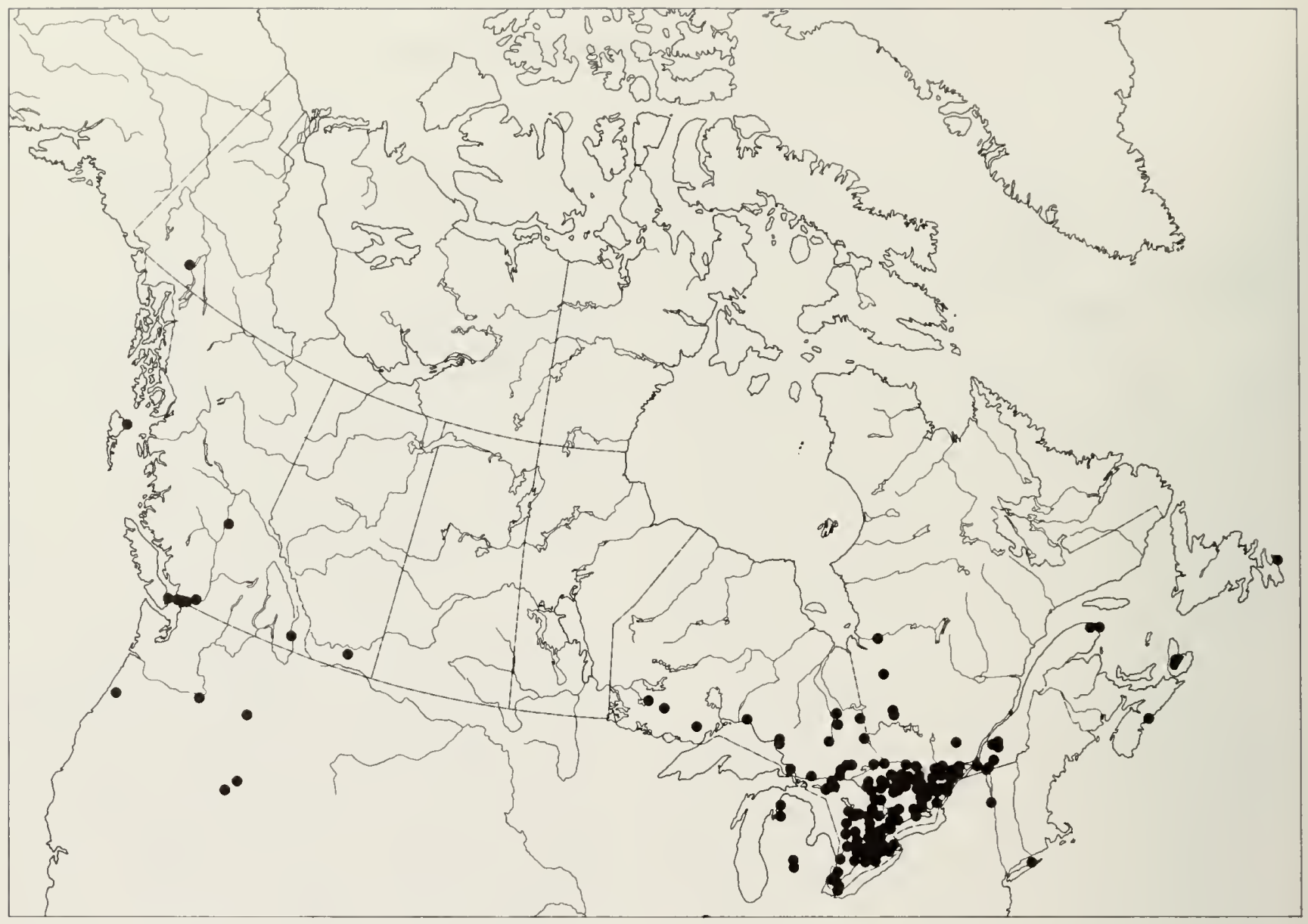

Map 2 Festuca arundinacea. 


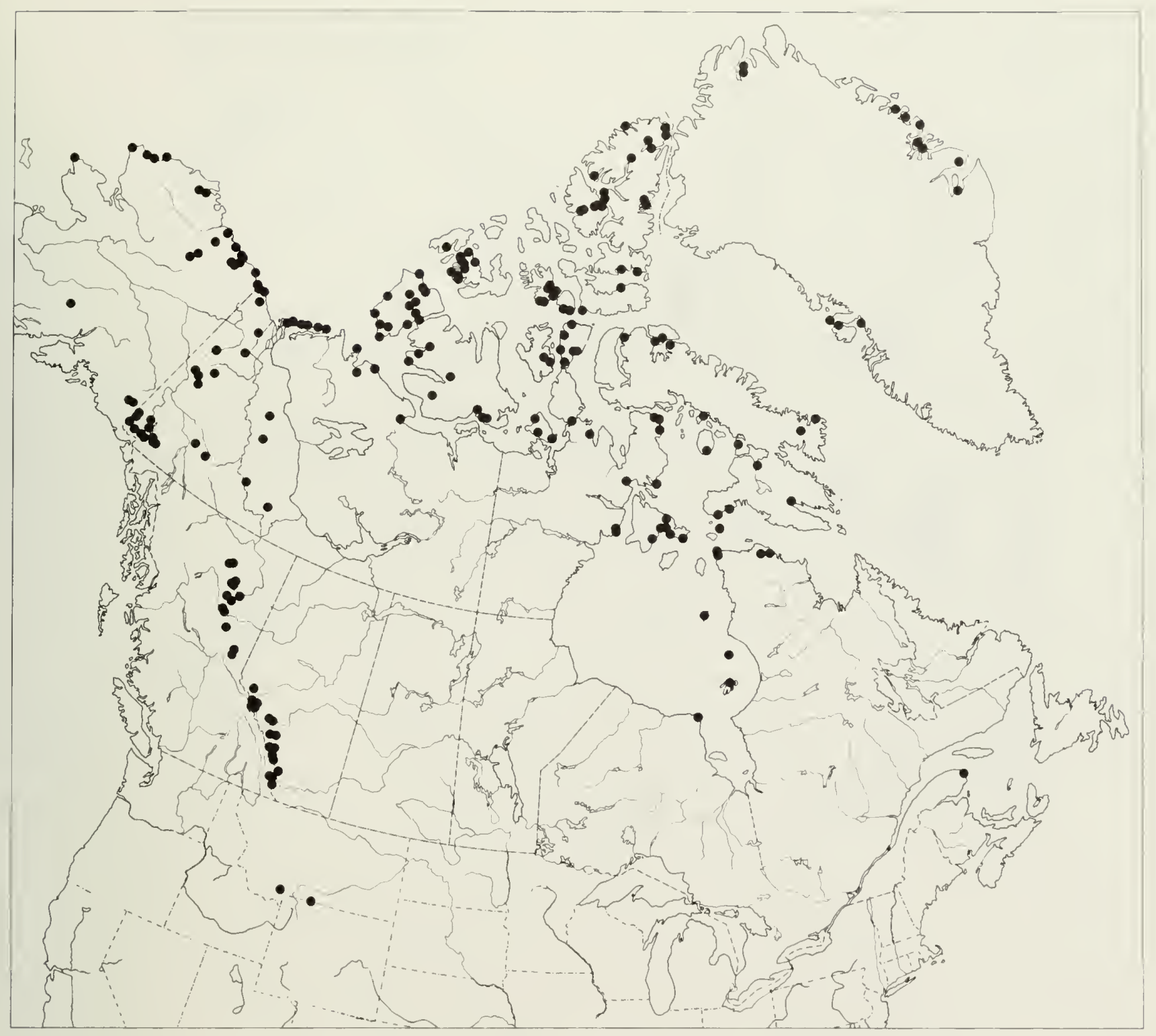

Map 3 Festuca baffinensis. 


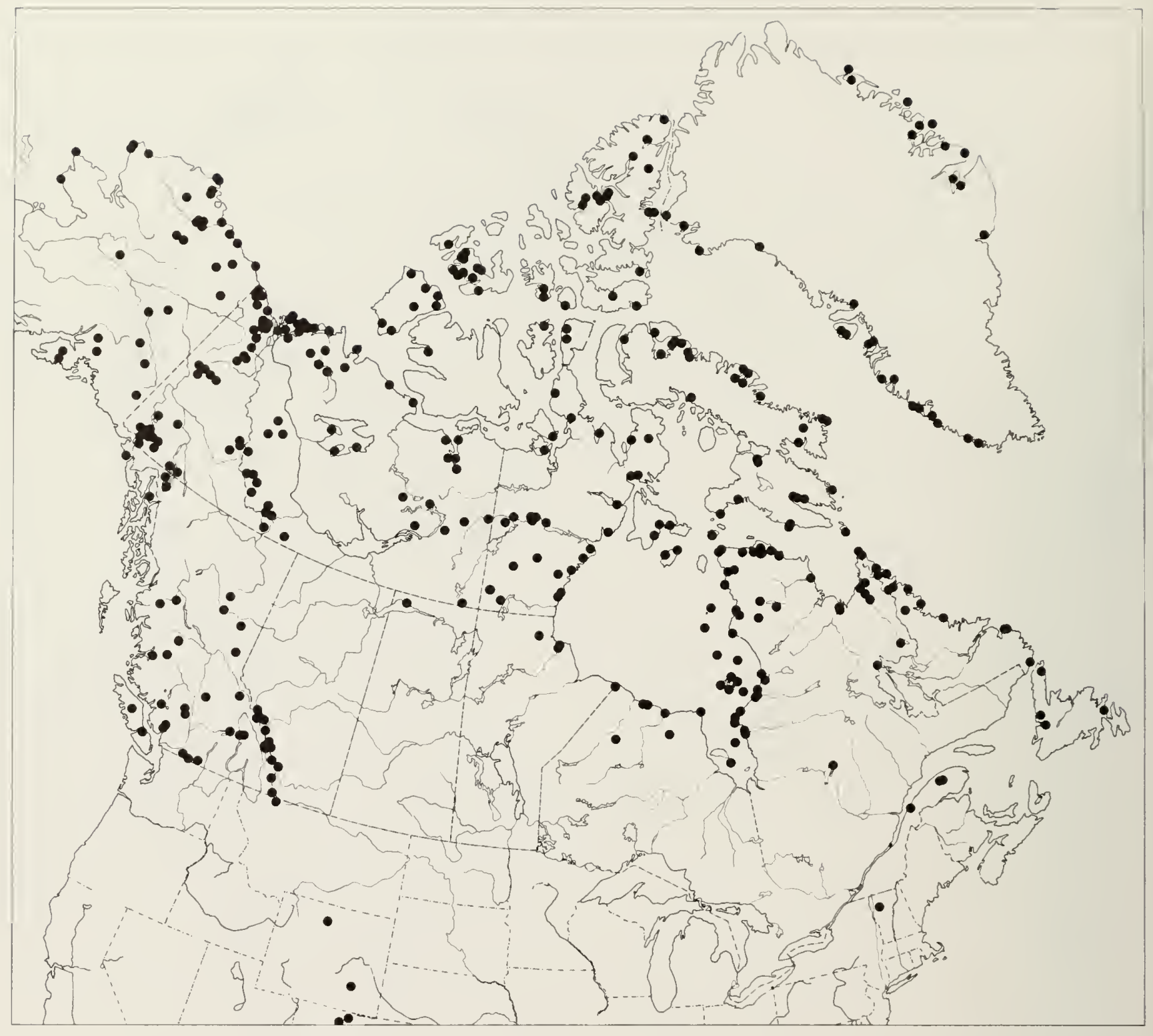

Map 4 Festuca brachyphylla. 


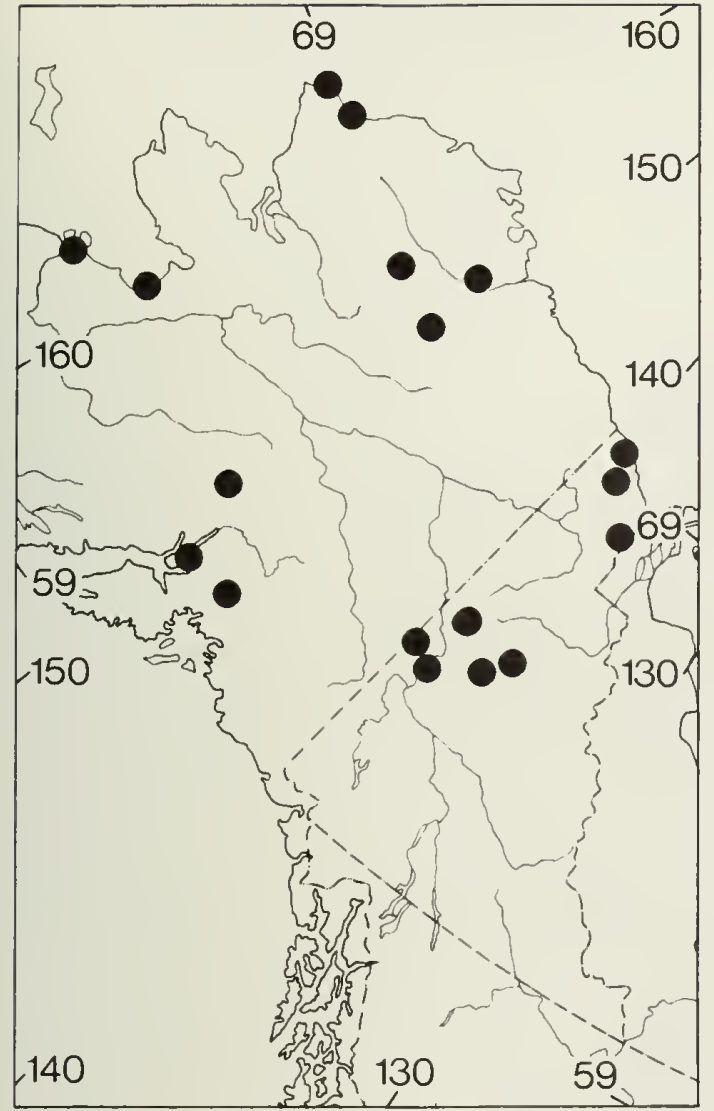

Map 5 Festuca brevissima.

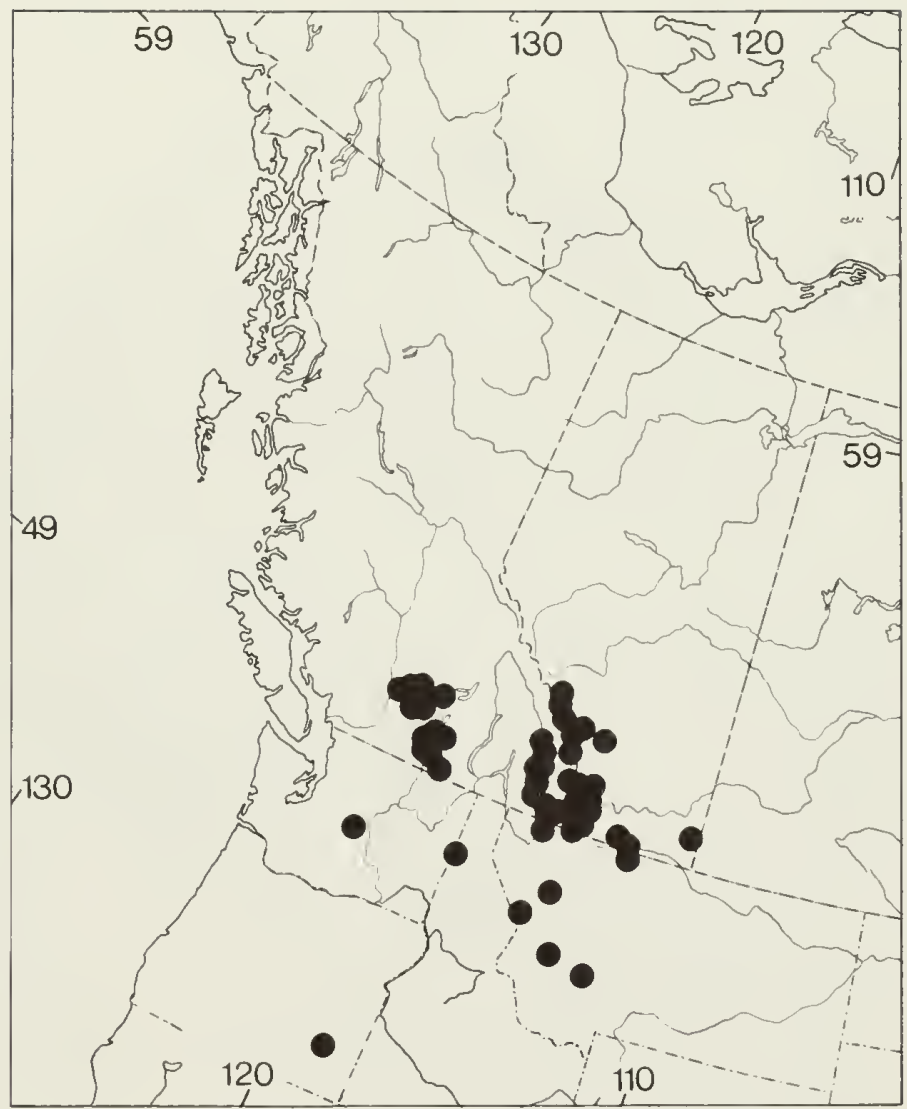

Map 6 Festuca campestris.

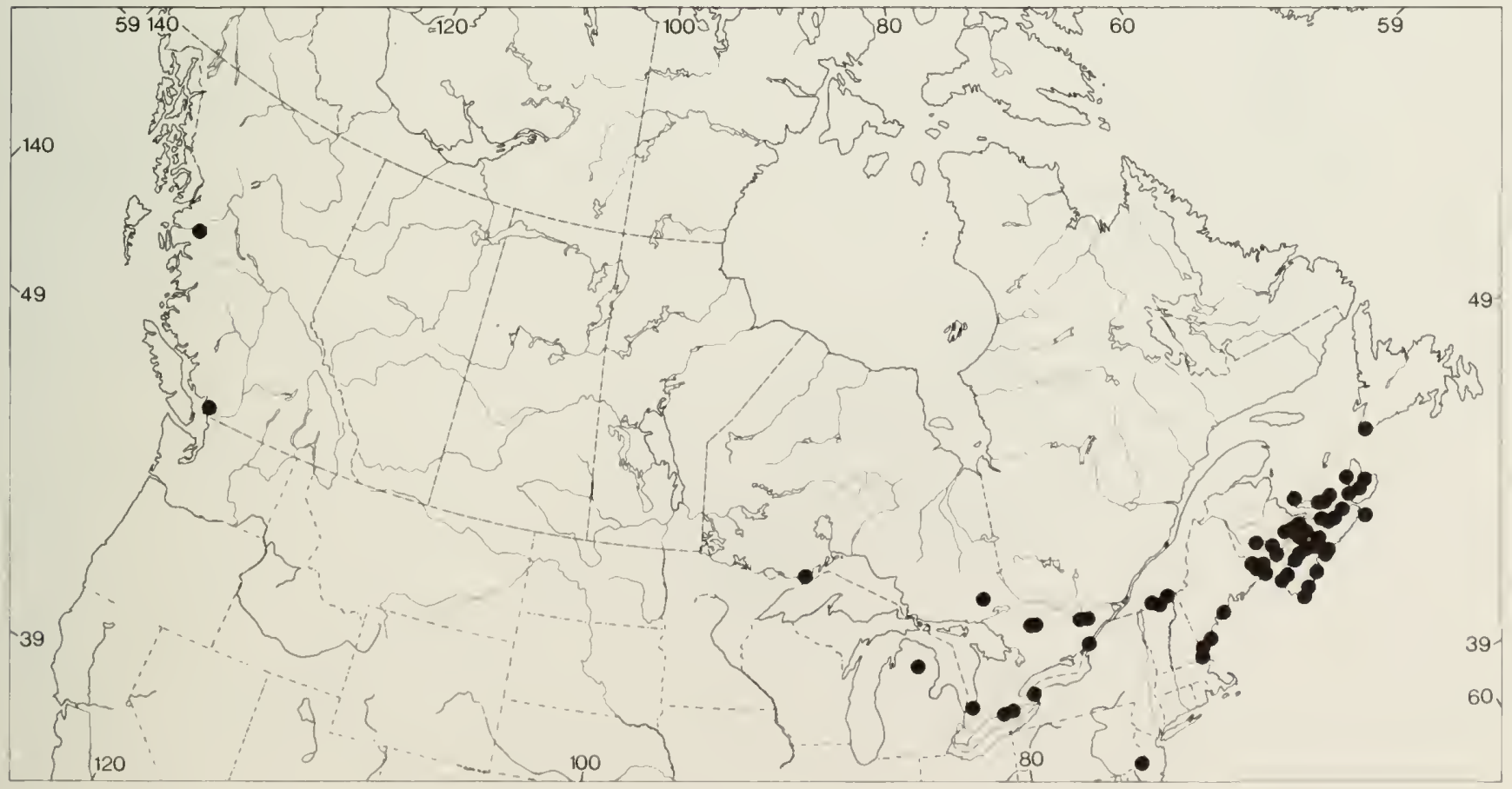

Map 7 Festuca filiformis. 


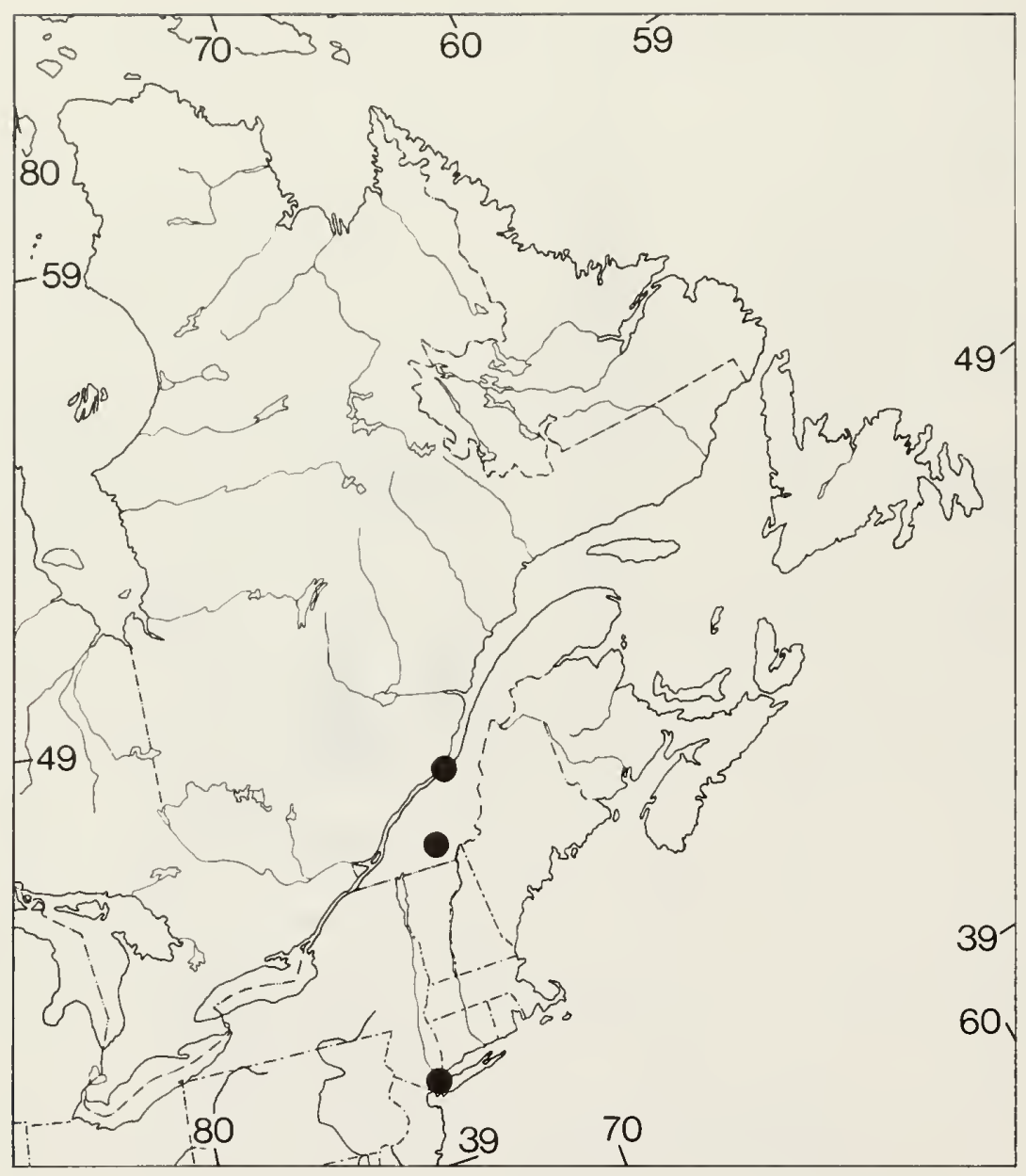

Map 8 Festuca gigantea.

Map 9 Festuca hallii.

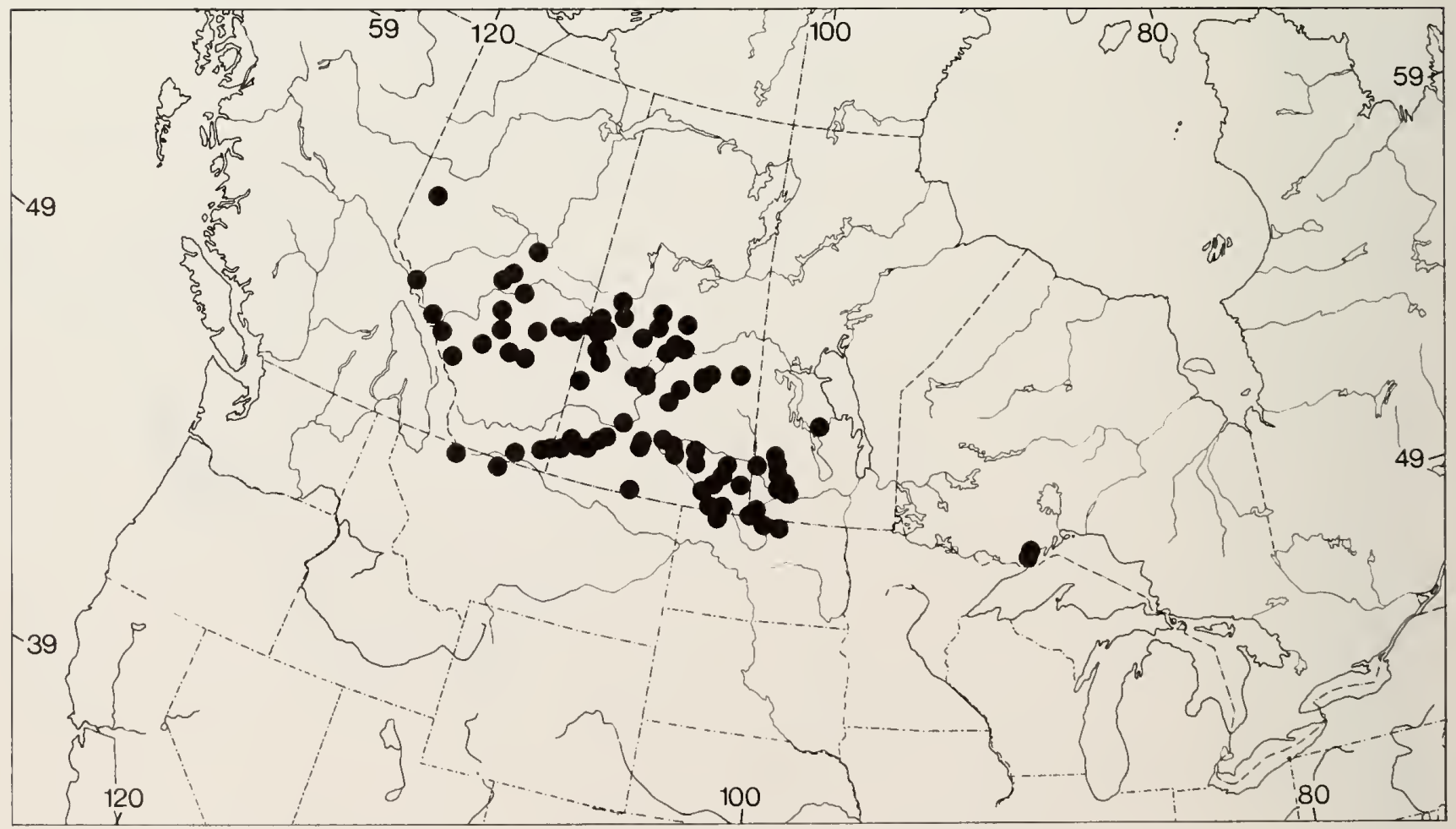




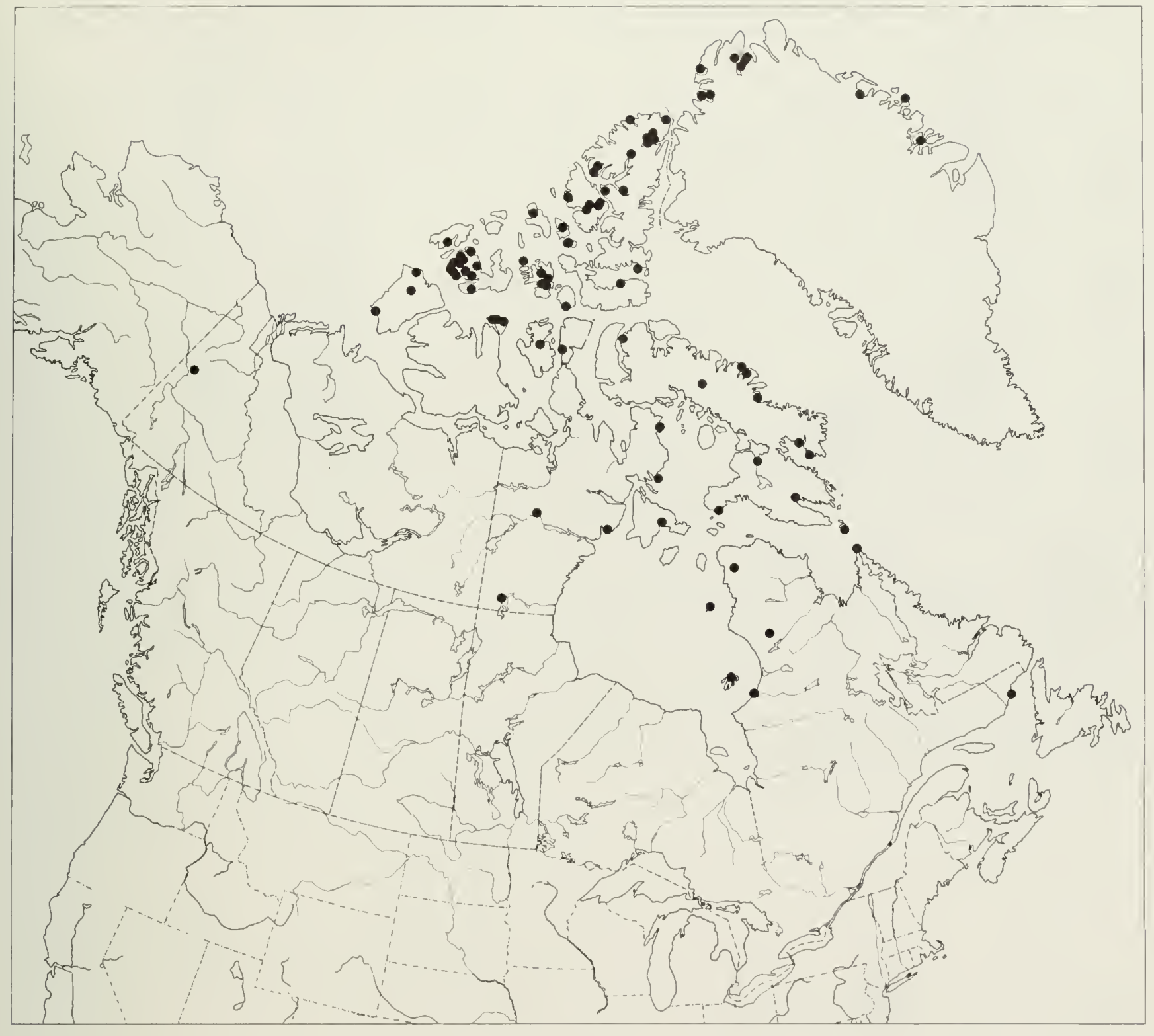

Map 10 Festuca hyperborea.

85 


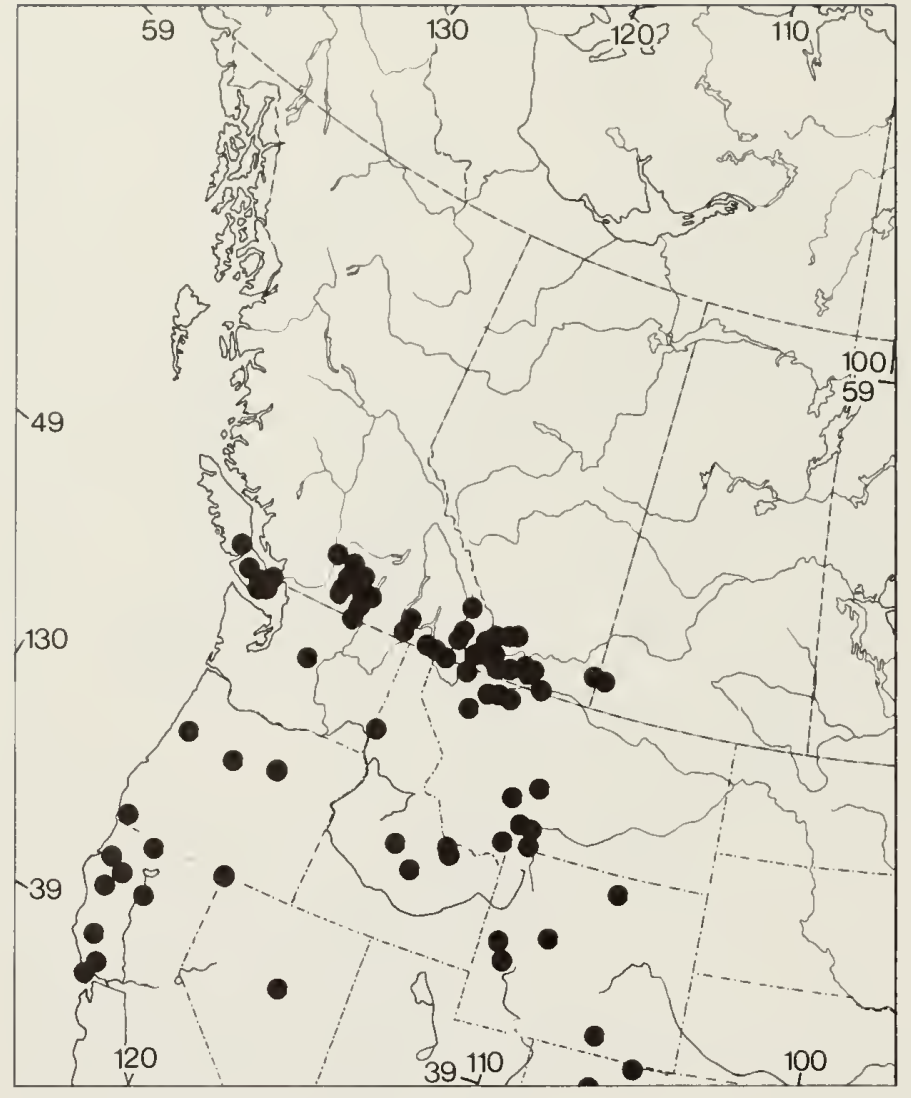

Map 11 Festuca idahoensis.

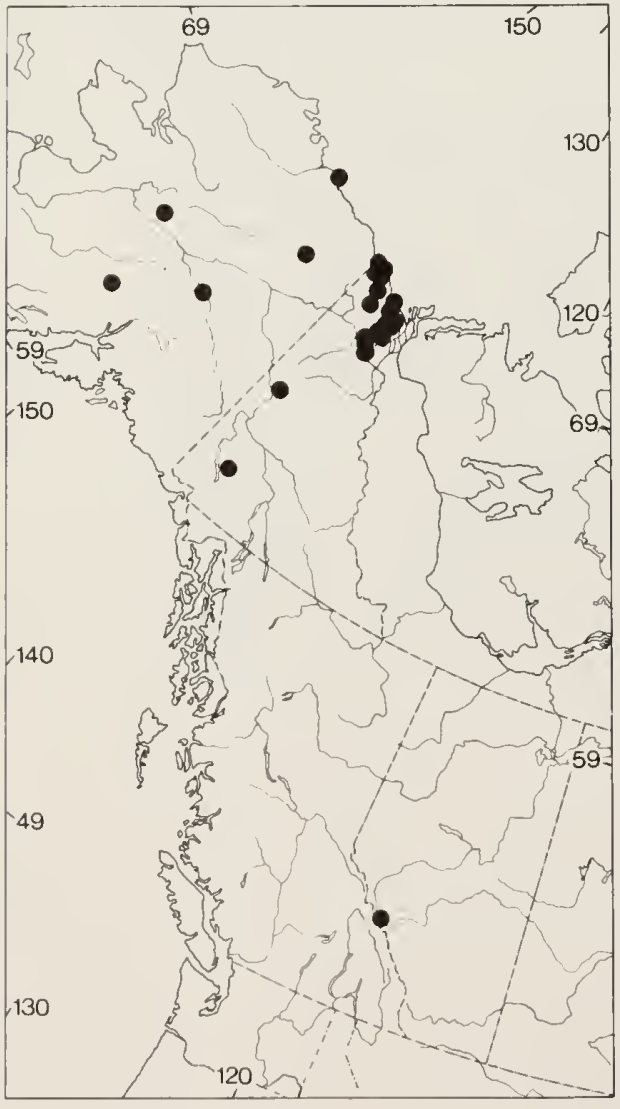

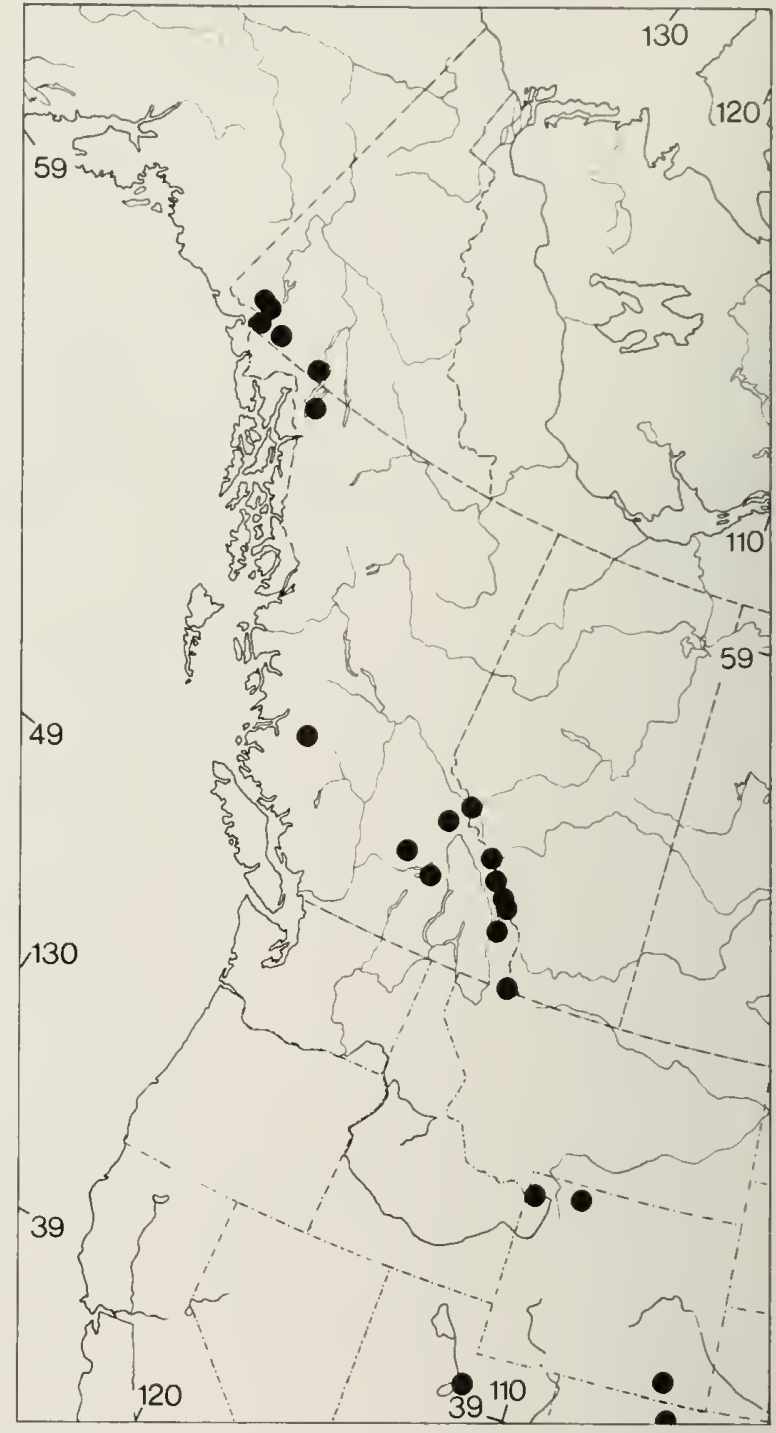

Map 13 Festuca minutiflora.

Map 12 Festucalenensis. 


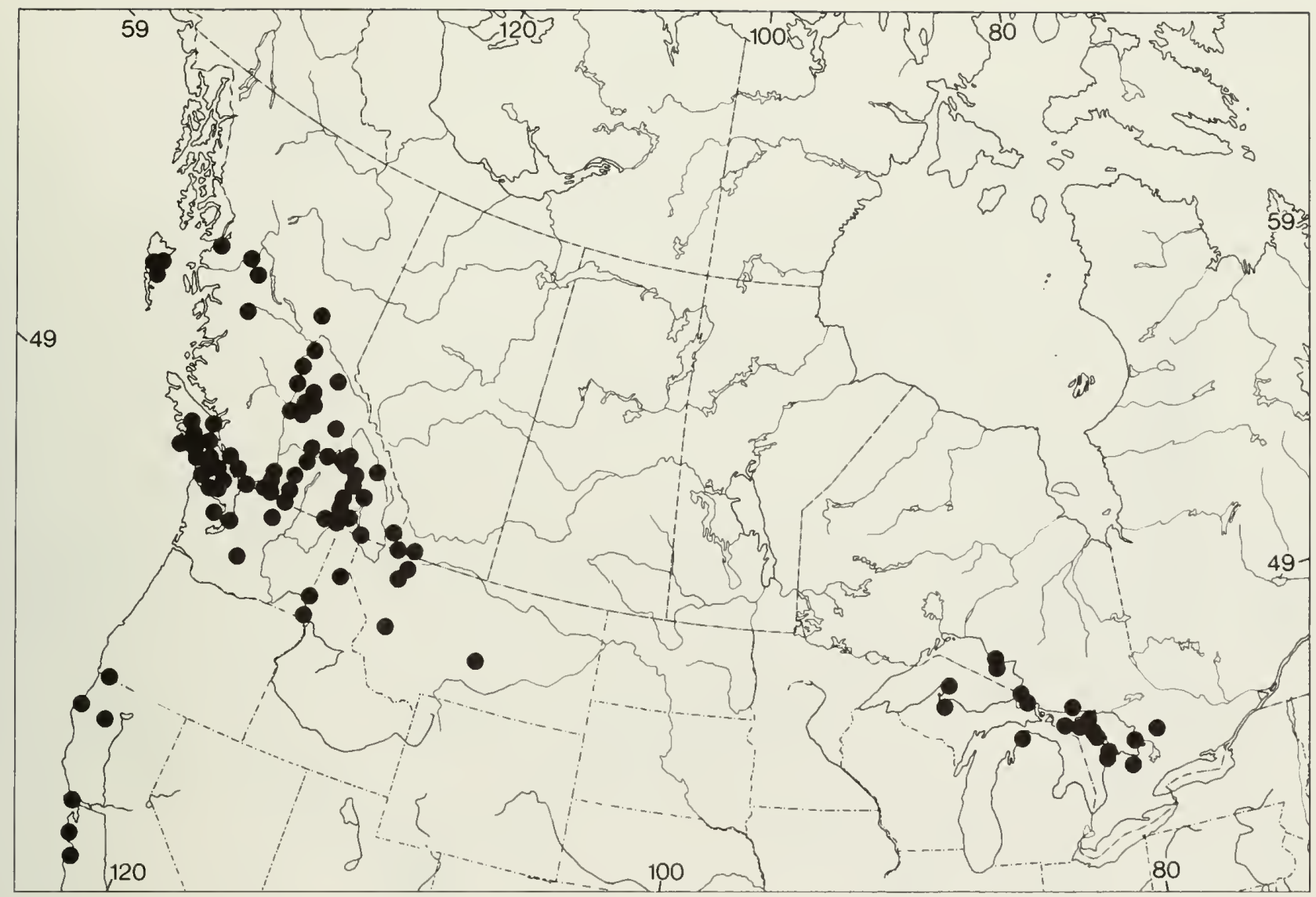

Map 14 Festuca occidentalis. 


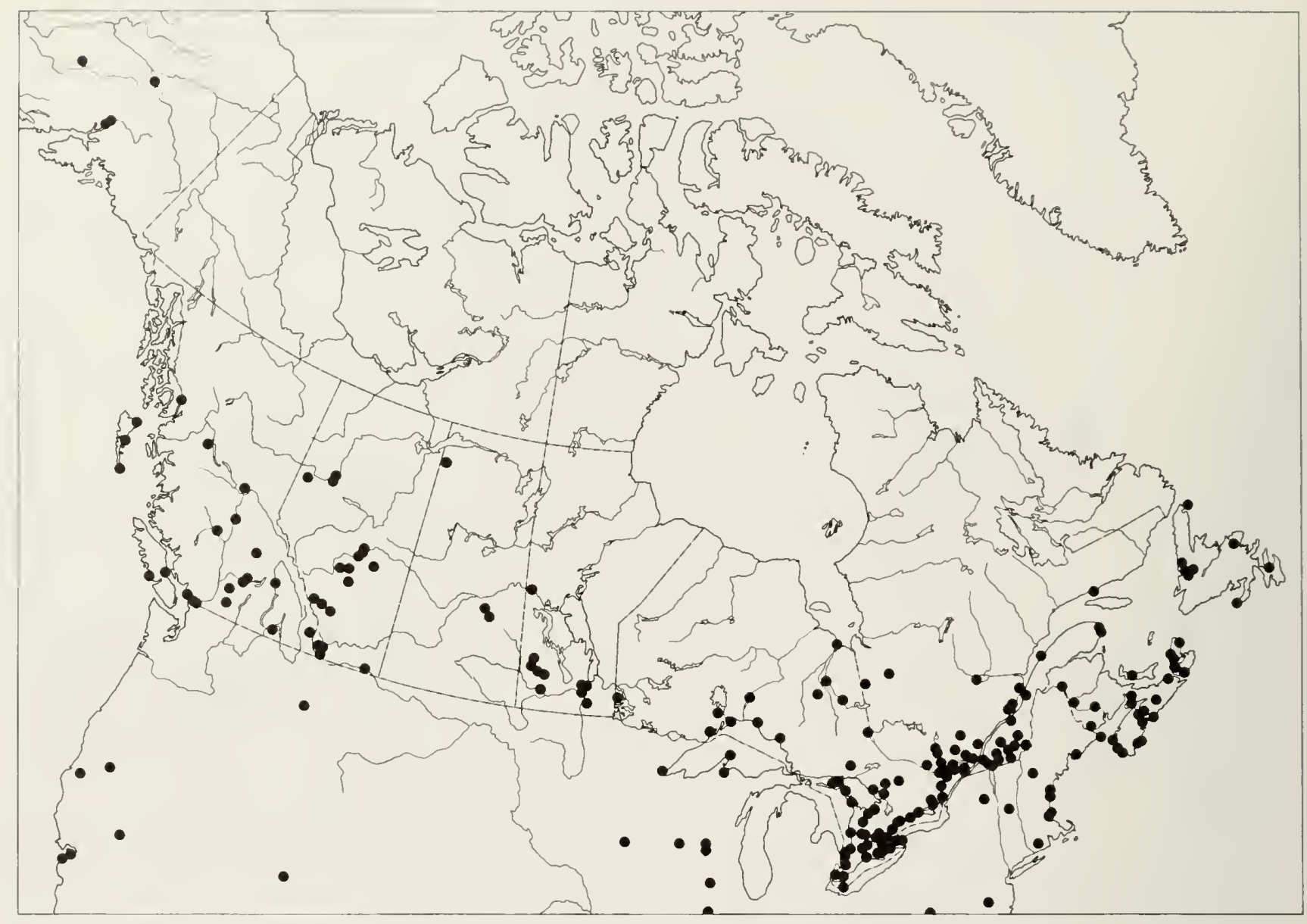

Map 15 Festuca pratensis. 


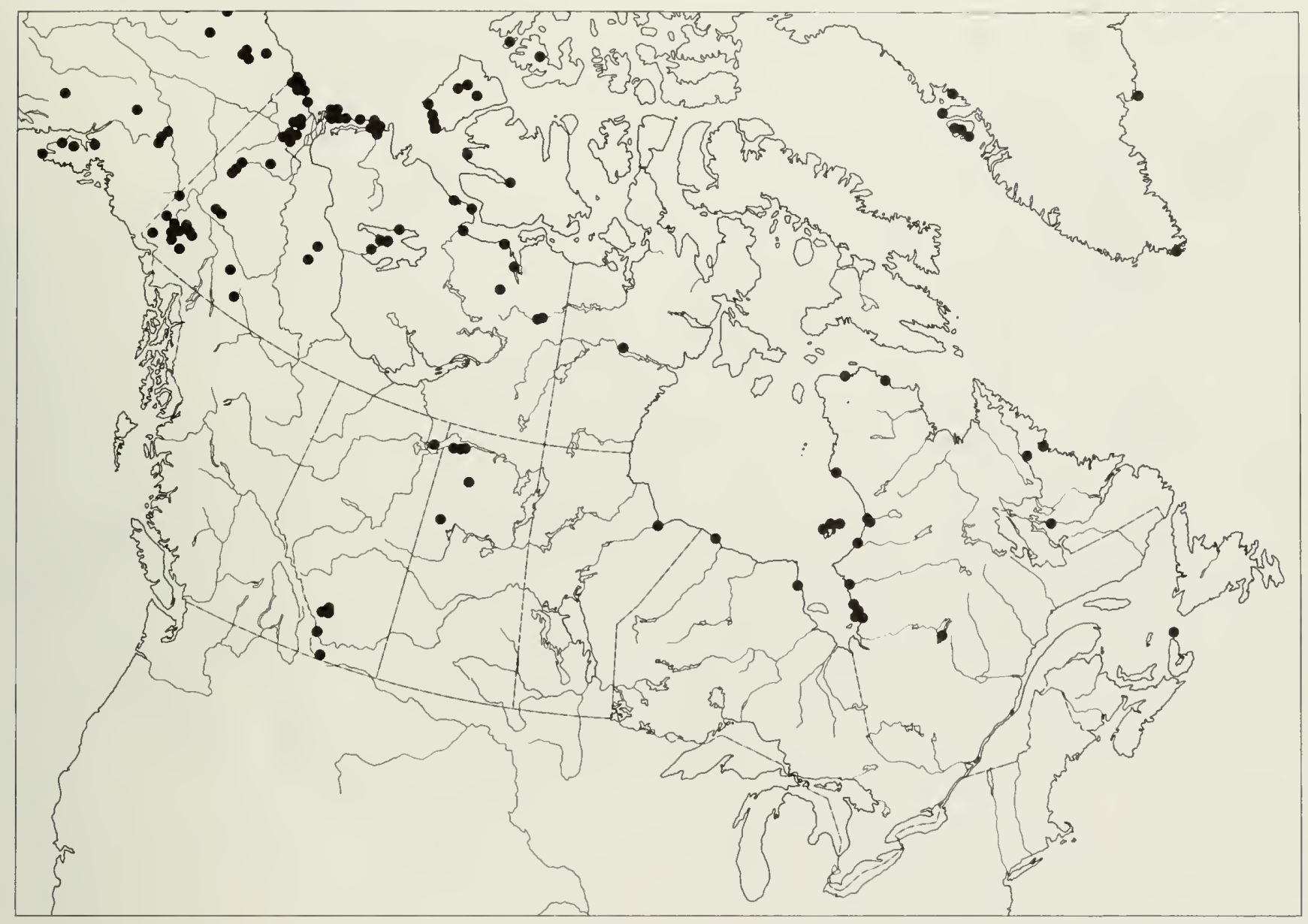

Map 16 Festuca richardsonii.

89 


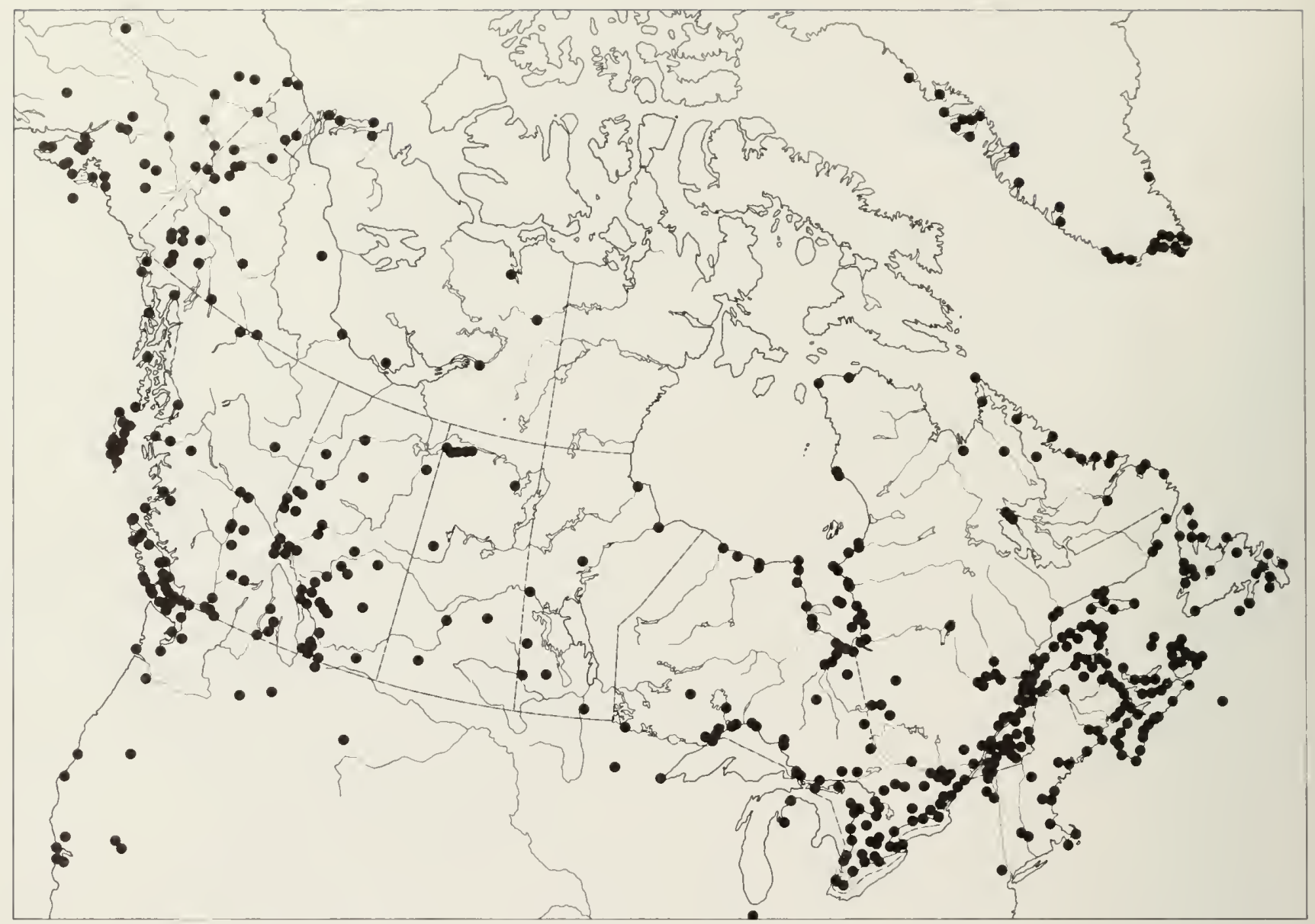

Map 17 Festuca rubra. 


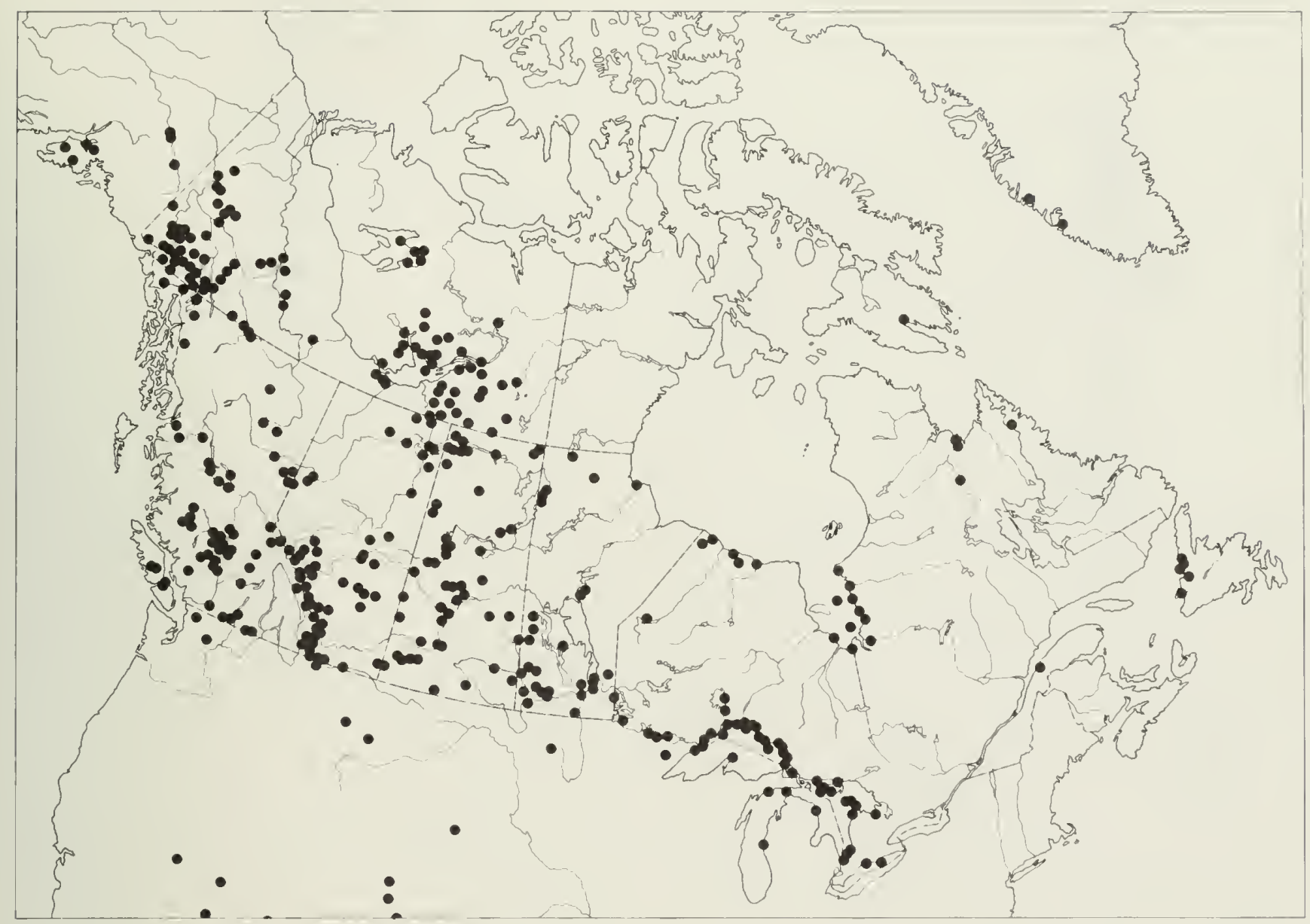

Map 18 Festuca saximontana. 


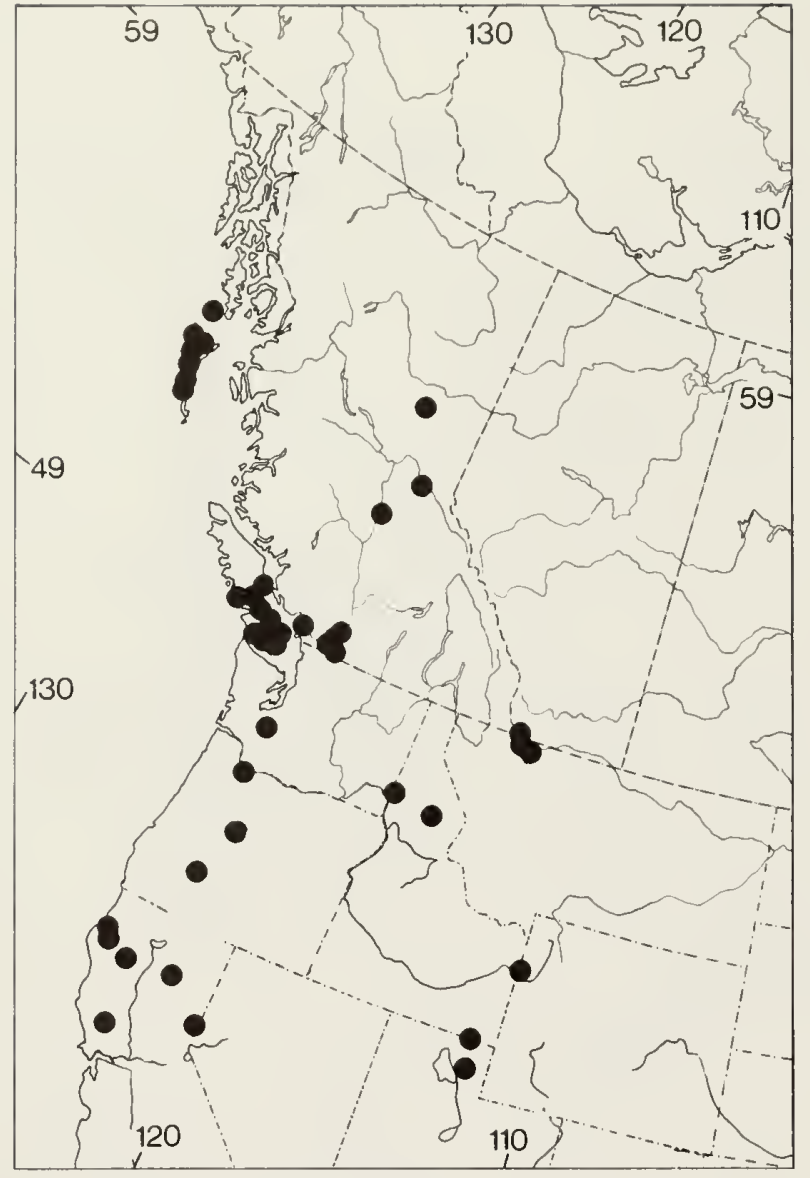

Map 19 Festuca subulata.

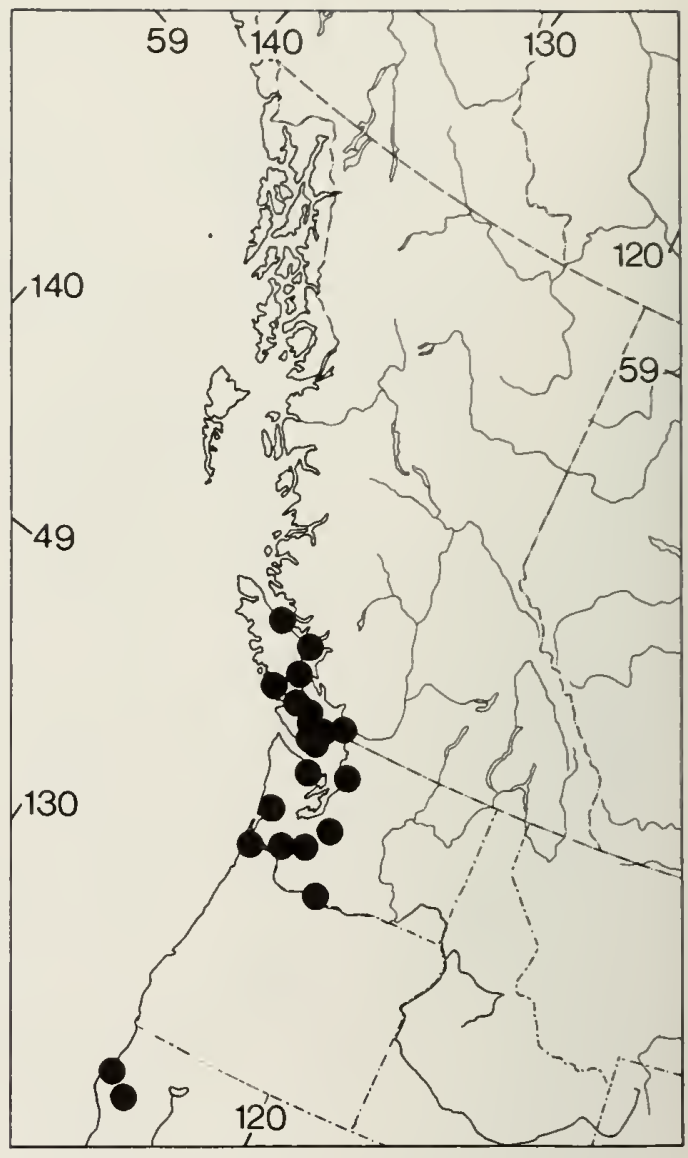

Map 20 Festuca subuliflora.

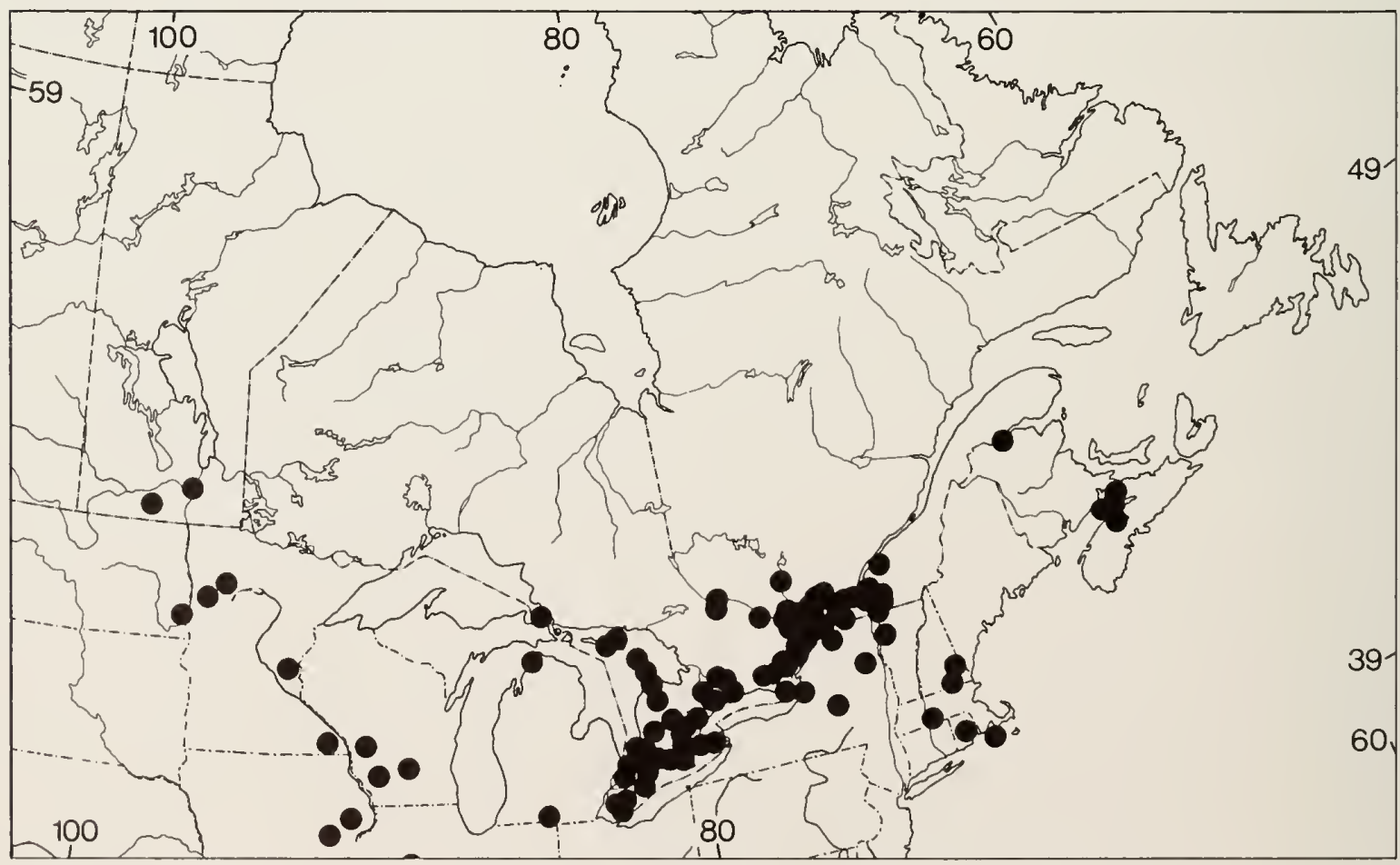

Map 21 Festuca subverticillata. 


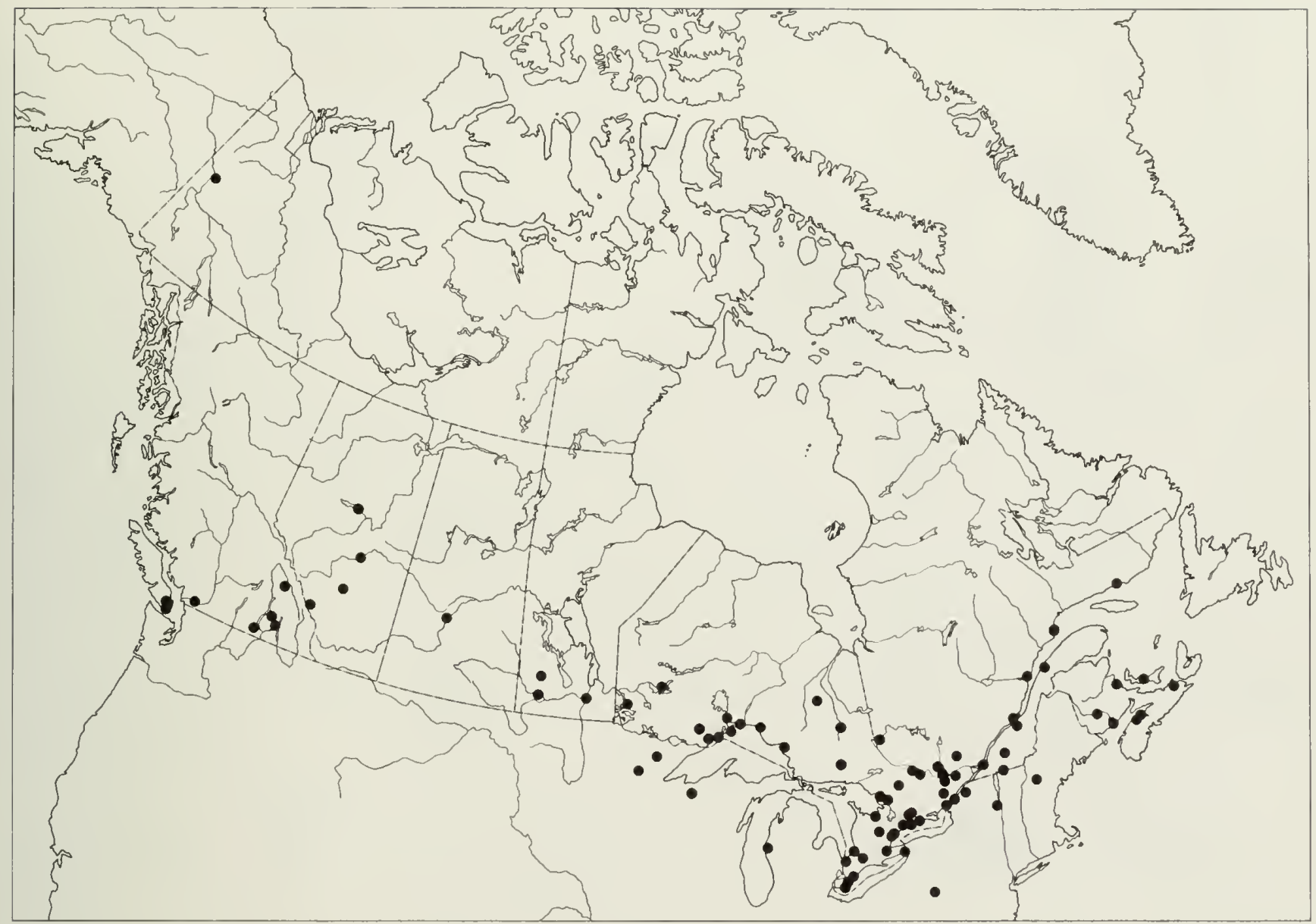

Map 22 Festuca trachyphylla. 


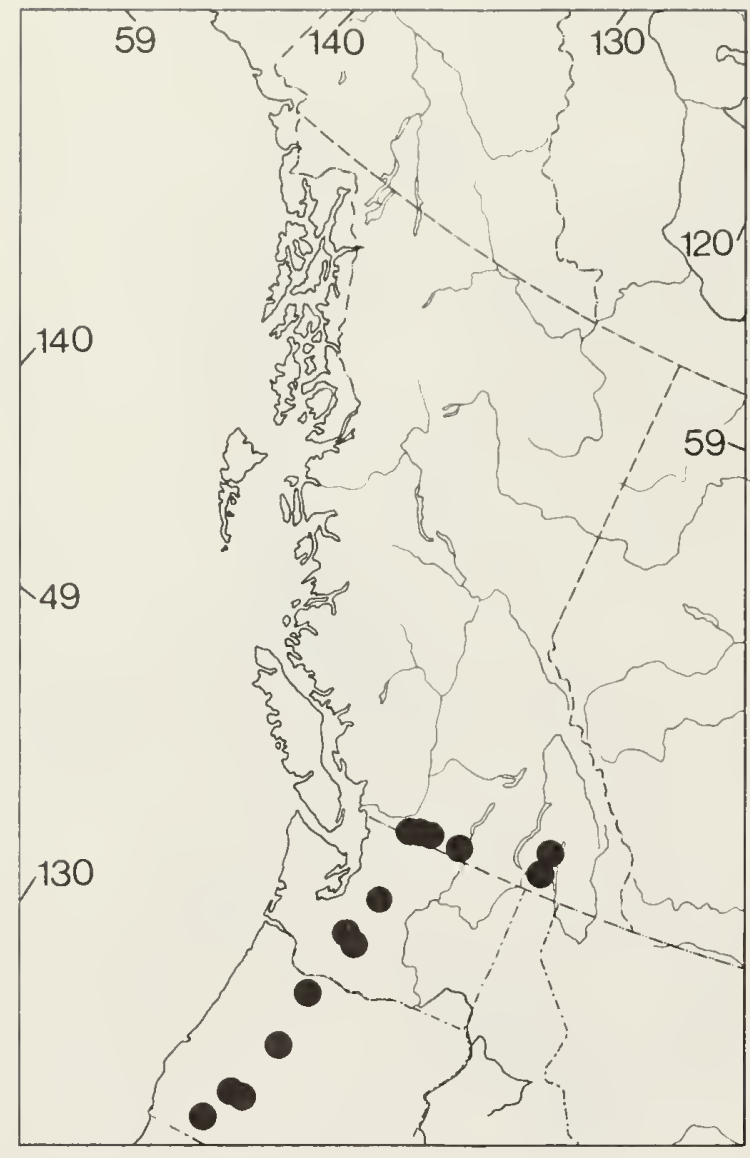

Map 23 Festuca viridula.

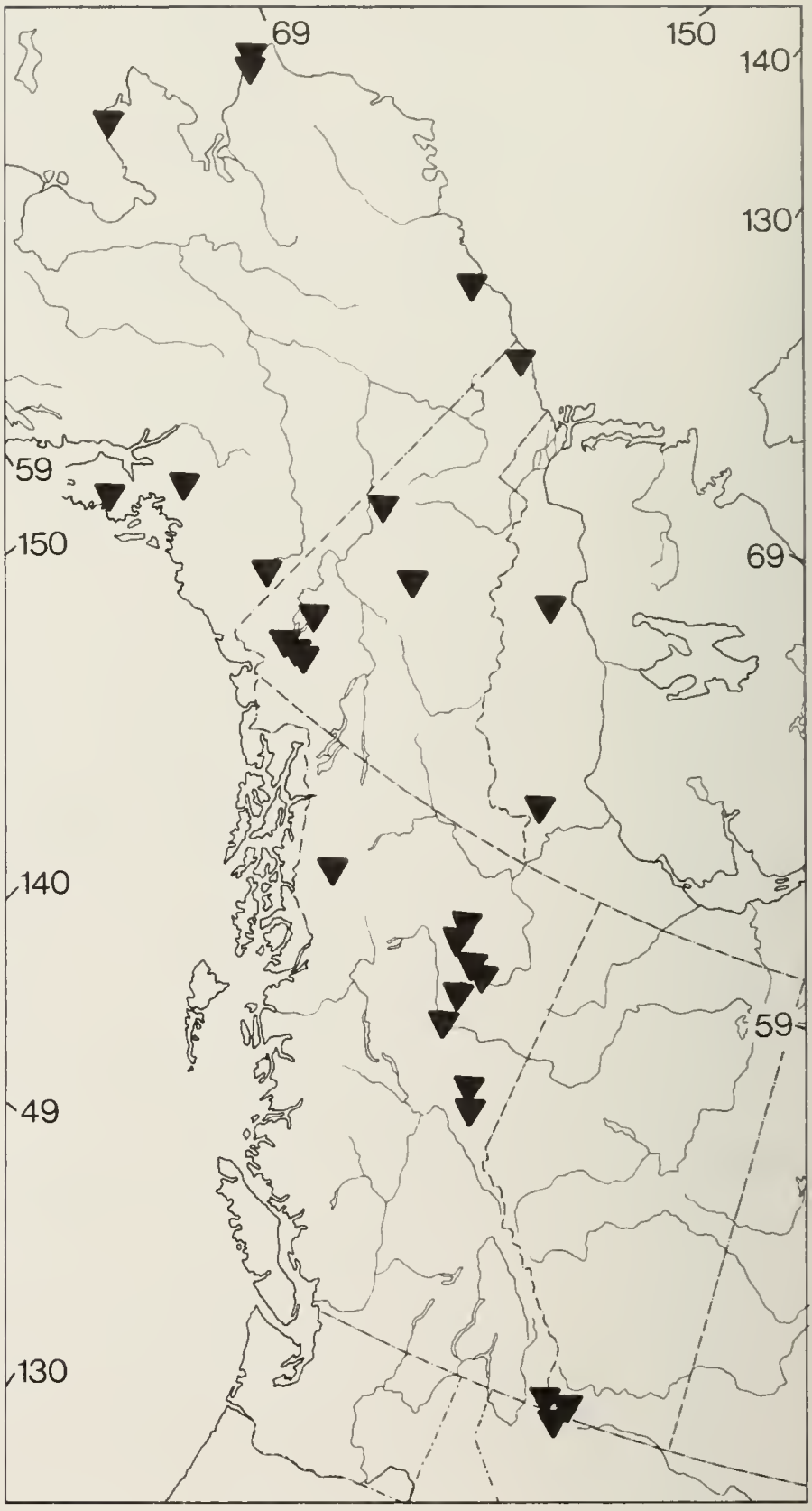

Map 24 Festuca vivipara ssp. glabra. 


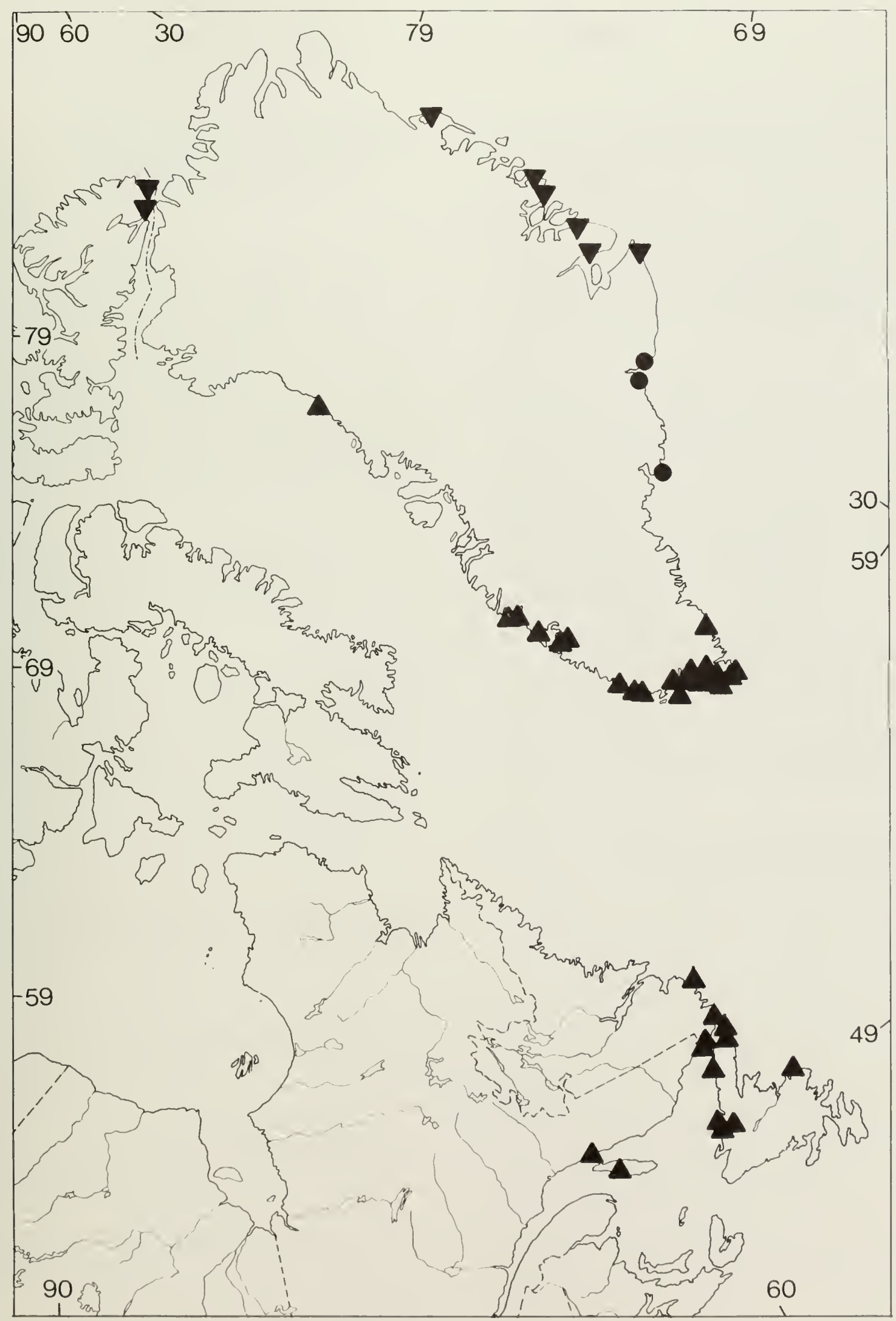

Map 25 Festuca vivipara ssp. vivipara $(\bullet)$, ssp. glabra $(\boldsymbol{\nabla})$, and ssp. hirsuta $(\boldsymbol{\Delta})$. 



\section{Literature cited}

Aiken, S.G.; Darbyshire, S.J.; Lefkovitch, L.P. 1985. Restricted taxonomic value of leaf sections in Canadian narrow-leaved Festuca (Poaceae). Can. J. Bot. 63:995-1007.

Aiken, S.G.; Lefkovitch, L.P. 1984. The taxonomic value of using epidermal characteristics in the Canadian rough fescue complex (Festuca altaica, $F$. campestris, $F$. hallii, " $F$. scabrella"). Can. J. Bot. 62:1864-1870.

Aiken, S.G.; Lefkovitch, L.E.; Darbyshire, S.J.; Armstrong, K.C. 1988. Vegetative proliferation in inflorescences of red fescue (Festuca rubra s.l., Poaceae). Can. J. Bot. 66:1-10

Ainscough, M.M.; Barker, C.M.; Stace, C.A. 1986. Natural hybrids between Festuca and species of Vulpia section Vulpia. Watsonia 16:143-151.

Alexeev, E.B. 1972. The significance of degree of integration of leaf vaginae of vegetative shoots in the systematism of Fescues of the group Festuca ovina L. s.1. Vestn. Mosk Univ. Ser. XVI Biol. 5:48-51 [in Russian].

Alexeev, E.B. 1975. Generis Festuca L. species angustifoliae partis Europaeae U.S.S.R. Novst. Sist. Vyssh. Rast. 12:11-43 [in Russian]

Alexeev, E.B. 1980. Festuca L. Subgenera et sections novae ex America boreali et Mexica. Novst. Sist. Vyssh. Rast. 17: 42-53 [in Russian].

Alexeev, E.B. 1982. New and little known Festuca of North America. Byull. Mosk. OVa Ispyt. Prir. Otd. Biol. 87:109-118 [in Russian].

Alexeev, E.B. 1984. Viviparous fescues (Festuca L., Gramineae) of South America. Byull. Mosk. O-Va Ispyt. Prir. Otd. Biol. 89:111-117 [in Russian].

Alexeev, E.B. 1985. Festuca L. (Poaceae) in Alaska et Canada. Novst. Sist. Vyssh. Rast. 22:5-35 [in Russian].

Arber, A. 1934. The Gramineae: A study of cereal, bamboo and grass. Camb. Univ. Press, Cambridge, U.K. 480 p.
Argus, G.W.; White, D.J. 1977. The rare vascular plants of Ontario./ Les plantes vasculaires rares de l'Ontario. Syllogeus 14. $63 / 66 \mathrm{p}$

Auquier, P. 1973. Festuca. Pages 683-691 in J.-E. de Langhe et al. Nouvelle flore de la Belgique, du Grand-Duché de Luxembourg, du Nord de la France et des régions voisines. Jard. Bot. Natl. Belg., Brussels. $821 \mathrm{p}$

Bacon, C.W.; Porter, J.K.; Robbins, J.D.; Luttrell, E.S. 1977. Epichloe typhina from toxic tall fescue grasses. Appl. Environ. Microbiol. 34:576-581.

Badoux, S. 1971. Sur l'anatomie de la feuille de Festuca arundinacea Schreb., Festuca pratensis Huds., Lolium multiflorum Lam. et leurs hybrides. Bull. Soc. Vaudoise Sci. Nat. 71:15-22.

Barker, C.M.; Stace, C.A. 1982. Hybridization in the genera Vulpia and Festuca; the production of artificial $F_{1}$ plants. Nord. J. Bot. 2:435-444.

Beetle, A.A. 1980. Vivipary, proliferation and phyllody in grasses. J. Range Manage. 33:256-261.

Berg, C.C.; Webster, G.U.; Jauhar, P.Q. 1979. Cytogenetics and genetics. Pages 93-109 in Buckner, R.C.; Bush, L.P. eds. Tall fescue. Am. Soc. Agronomy, Crop. Sci. Soc. Am., and Soil Sci. Soc. Am., Madison, Wis.

Bews, J.W. 1929. The World's grasses. Longmans, Green and Co., Toronto, Ont. 408 p.

Boivin, B. 1967. Enumération des plantes du Canada VI. Monopsides. Nat. Can. (Qué.) 94:471-528.

Boivin, B. 1981. Flora of the Prairie Provinces. A handbook to the flora of the Provinces of Manitoba, Saskatchewan, and Alberta. Part V. Gramineae.

Provancheria $12.108 \mathrm{p}$.

Borrill, M.C.; Tyler, B.; Lloyd-Jones, M. 1971. Studies in Festuca I. A chromosome atlas of Bovinae and Scariosae. Cytologia 36:1-14. 
Bowden, W.M. 1960. Chromosome notes and taxonomic notes on northern grasses. II.

Tribe Festuceae. Can. J. Bot. 38:541-557.

Buckner, R.C.; Bush, L.P. 1979. Tall fescue. Am. Soc. Agronomy, Crop. Sci. Soc. Am., and Soil Sci. Soc. Am., Madison, Wis. $351 \mathrm{p}$.

Burns, J.C.; Chamblee, D.S. 1979. Adaptation. Pages 9-30 in Buckner, R.C.; Bush L.P. eds. Tall fescue. Am. Soc. Agronomy, Crop. Sci. Soc. Am., and Soil Sci. Soc. Am., Madison, Wis.

Butkute, B.L.; Konarev, A.V. 1982. Studies of the seed proteins in the genera Lolium and Festuca (Poaceae) in relation to their phylogeny. Bot. Zh. (Leningr.) 67:812-819 [in Russian].

Clay, K. 1988. Fungal endophytes of grasses: A defensive mutualism between plants and fungi. Ecology 69:10-16.

Clayton, W.D.; Renvoize, S.A. 1986. Genera Graminum. Grasses of the World. Kew Bull. Addit. Ser. 13. 389 p.

Cohen, C.J.; Chilcote, D.O.; Frakes, R.V. 1982a. Leaf anatomy and stomatal characteristics of four tall fescue selections differing in forage yield. Crop Sci. 22:704-708.

Cohen, C.J.; Chilcote, D.O.; Frakes, R.V. 1982b. Gas exchange and leaf area characteristics of four tall fescue selections differing in forage yield. Crop Sci. 22:709-711.

Conners, I.L. 1967. An annotated index of plant disease fungi in Canada and fungi recorded on plants in Alaska, Canada and Greenland. Can. Dep. Agric. Publ. 1251. $381 \mathrm{p}$.

Crompton, C.W.; McNeill, J.; Stahevitch, A.E.; Wojtas, W.A. 1988. Preliminary inventory of Canadian weeds. Agric. Can. Tech. Bull. 1988-9E. 292 p.

Cronquist, A.; Holmgren, A.H.; Holmgren, N.H.; Reveal, J.L.; Holmgren, P.K. 1977. Intermountain flora. Vascular plants of Intermountain West, U.S.A. Vol. 6. Columbia Univ. Press, New York, N.Y. $584 \mathrm{p}$.

Crowder, L.V. 1953. A survey of meiotic chromosome behaviour in tall fescue grass. Am. J. Bot. 40:348-354.
Crowder, L.V. 1956. Morphological and cytological studies in tall fescue (Festuca arundinacea Schreb.) and meadow fescue (F. elatior L.). Bot. Gaz. 117:214-223.

Diehl, W.W. 1950. Balansia and the Balansiae in America. U.S. Dep. Agric. Monogr. No. 4.82 p.

Dore, W.G.; McNeill, J. 1980. Grasses of Ontario. Agric. Can. Monogr. 26. 566 p.

Dubé, M. 1983. Addition de Festuca gigantea (L.) Vill. (Poaceae) à la flore du Canada. Nat. Can. (Qué.) 110:213-215.

Dubé, M.; Morisset, P. 1987. Morphological and leaf anatomical variation in Festuca rubra sensu lato (Poaceae) from eastern Quebec. Can. J. Bot. 65:1065-1077.

Dubé, M.; Morisset, P.; Murdock, J. 1985. Races chromosomiques chez Festuca rubra sensu lato (Poaceae) dans l'est du Québec. Can. J. Bot. 63:227-231.

Duke, J.A.; Terrell, E.E. 1974. Crop diversification matrix: Introduction. Taxon 23:759-799.

Duyvendak, R.; Luesink, B.; Vos, H. 1981. Delimitation of taxa and cultivars of red fescue (Festuca rubra L. sensu lato). Rasen 3:53-61.

Elven, R. 1980. The Omnsbreen Glacier nunataks-A case history of plant immigration. Norw. J. Bot. 27:1-16.

Evans, G.M.; Asay, K.H.; Jenkins, R.G. 1973. Meiotic irregularities in hybrids between diverse genotypes of tall fescue (Festuca arundinacea Schreb.). Crop Sci. 13:373-379.

Fernald, M.L. 1950. Gray's manual of botany. 8th ed. Am. Book Co., New York, N.Y. $1632 \mathrm{p}$.

Flovik, K. 1938. Cytological studies on arctic grasses. Hereditas 24: 265-376.

Frederiksen, S. 1977. The Festuca brachyphylla group in Greenland. Bot. Not. 130:269-277.

Frederiksen, S. 1978. Festuca brevissima Jurtz. in Alaska. Bot. Not. 131: 409-410.

Frederiksen, S. 1979. Festuca minutiflora Rydb., a neglected species. Bot. Not. 132:315-318.

Frederiksen, S. 1981. Festuca vivipara (Poaceae) in the North Atlantic area. Nord. J. Bot. 1:277-292. 
Frederiksen, S. 1982 [1983]. Festuca brachyphylla, $F$. saximontana and related species in North America. Nord. J. Bot. 2:525-536.

Frederiksen, S. 1983. Festuca auriculata in North America. Nord. J. Bot. 3: 629-632.

Ginns, J.H. 1986. Compendium of plant disease and decay fungi in Canada. 1960-1980. Agric. Can. Publ. 1813. 416 p.

Gould, F.W.; Shaw, R.B. 1983. Grass systematics. 2nd. ed. Texas A \& M Univ. Press, College Station, Tex. 397 p.

Hackel, E. 1882. Monographia Festucarum Europaerum. Theodor Fischer, Berlin, Germany. $216 \mathrm{p}$.

Harmer, R. 1984. Vegetative proliferation and vivipary in Scottish grasses. Bot. Soc. Edinb. Trans. 44:261-268.

Harmer, R.; Lee, J.A. 1978. The growth and nutrient content of Festuca vivipara (L.) Sm. plantlets. New Phytol. 80:99-106.

Harms, V.L. 1985. A reconsideration of the nomenclature and taxonomy of the Festuca altaica complex in North America. Madroño 32:1-10.

Hedberg, O. 1967. Chromosome numbers of vascular plants from arctic and subarctic North America. Ark. Bot. Ser. 2. 6:309-326.

Heide, O.H. 1988. Environmental modification of flowering and viviparous proliferation in Festuca vivipara and F. ovina. Oikos 51:171-178.

Hitchcock, A.S. 1935. Manual of the grasses of the United States. U.S. Dep. Agric. Misc. Publ. 200. 1040 p.

Hitchcock, A.S.; Chase, A. 1951. Manual of the grasses of the United States, 2nd. ed. U.S. Dep. Agric. Misc. Publ. 200. 1051 p.

Hitchcock, C.L.; Cronquist, A.; Ownbey, M.; Thompson, J.W. 1969. Vascular plants of the Pacific Northwest. Univ. of Wash. Press, Seattle, Wash. Part 1. 914 p.

Holmen, K. 1952. Cytological studies in the flora of Peary Land North Greenland. Medd. Grønl. 128:1-40.

Holmen, K. 1964. Cytotaxonomical studies in the Arctic Alaskan flora. Bot. Not. 117:109-118.

Holmgren, P.K.; Keuken, W.; Schofield, E.K. 1981. Index Herbariorum. Bohn, Scheltema and Holkema, Utrecht. 455 p.
Hooker, W.J. 1840. Festuca. Pages 249-252 in Flora Boreali-Americana vol. 2. Henry G. Bohn, London.

Howarth, W.D. 1924. Festuca rubra in Britain. J. Linn. Soc. Lond. Bot. 46:29-39.

Howarth, W.D. 1925. On the occurrence and distribution of Festuca ovina L. sensu amplis, in Britain. J. Linn. Lond. Soc. Bot. 47:313-331.

Howe, G.M. 1987. Forage cultivar trials1987. Agric. Can. Beaverlodge, Alta. $28 \mathrm{p}$.

Hultén, E. 1942. Flora of Alaska and Yukon. II. Lunds. Univ. Arsskr. N.F., Avd. 2, Bde. 38:131-412.

Hultén, E. 1968. Flora of Alaska and neighboring territories. Stanford Univ. Press, Stanford, Calif. 1008 p.

Hunt, K.L.; Sleper, D.A. 1981. Fertility of hybrids between two geographic races of tall fescue. Crop Sci. 21:400-404.

Huon, A. 1965. Caractères épidermiques distinctifs des ssp. arundinacea (Schreb.) Hack. et pratensis (L.) Hack. du Festuca elatior (L.) Hack. Bull. Soc. Bot. Fr. 112:37-42.

Jenkin, T.J. 1922. Notes on vivipary in Festuca ovina. Bot. Exch. Club. Rep. 6:418-432.

Johnston, A.; Cosby, H.E. 1966. Rhizomatous form of Festuca scabrella. Can. J. Plant Sci. 46:211-212.

Johnson, A.W.; Packer, J.G. 1968.

Chromosome numbers in the flora of Ogotoruk Creek, N.W. Alaska. Bot. Not. 121:403-456.

Jordal, L.H. 1952. Some new entities in the flora of the Brooks Range region, Alaska. Rhodora 54:35-39.

Jurtzev, B.A.; Zhukova, P.G. 1978. The cytotaxonomical survey of the monocots of the eastern most Chukchi Peninsula. Bot. Zh. (Leningr.) 63:1132-1144 [in Russian].

Kerguélen, M. 1975. Les Gramineae (Poaceae) de la flore française: essai de mise au point taxonomique et nomenclaturale. Lejeunia ser. 2, 75:1-343. 
Latch, G.C.M.; Christensen, M.J.; Samuerls, G.J. 1984. Five endophytes of Lolium and Festuca in New Zealand. Mycotaxon 20:535-550.

Latch, G.C.M.; Potter, L.R.; Tyler, B.F. 1987. Incidence of endophytes in seeds from collections of Lolium and Festuca species. Ann. Appl. Biol. 111:59-64.

Lehväslaiho, H.; Saura, A.; Lokki, J. 1987. Chloroplast DNA variation in the grass tribe Festuceae. Theor. Appl. Genet. 74:298-302.

Lewis, E.J. 1963. Hybrids between geographical races of Festuca arundinacea Schreb. Rep. Welsh Plant Breeding Stn. 1962. pp. 26-27.

Lhamby, J.C. 1978. Physiological characteristics of different forage yielding tall fescue (Festuca arundinacea Schreb.) selections under field sward conditions. M.S. thesis, Oregon State Univ.

Lonard, R.I.; Gould, F.W. 1974. The North American species of Vulpia (Gramineae). Madroño 22:217-280.

Looman, J. 1969. The fescue grasslands of western Canada. Vegetatio 19: 129-145.

Looman, J. 1982. Grasslands of western North America: Fescue grasslands. Pages 209221 in Nicholson, A.C.; McLean, A.; Baker, T.E. eds. Grassland ecology and classification Symposium Proceedings. Kamloops, B.C.

Looman, J.; Best, K.G. 1979. Budd's flora of the Canadian Prairie Provinces. Agric. Can. Publ. 1662. 862 p.

Löve, Á.; Löve, D. 1956. Cytotaxonomical conspectus of the Icelandic flora. Acta Horti Gotob. 20:65-291.

Löve, Á.; Löve, D. 1975. Cytotaxonomical atlas of the arctic flora. J. Cramer, Vaduz. $598 \mathrm{p}$.

Macoun, J. 1890. Catalogue of Canadian plants. Additions and corrections to parts I-IV. Pages 249-428 in Vol. 2, part V. Acrogens. Dawson Bros., Montreal, Que.

Markgraf-Dannenberg, I. 1980. Festuca. Pages 125-153 in Tutin, T.G.; Heywood, V.H.; Burges, N.A.; Moore, D.M.; Valentine, D.H.; Walters, S.M.; Webb, D.A. eds. Flora Europaea 5. Camb. Univ. Press, Cambridge, U.K.
Maude, P.F. 1940. Chromosome numbers in some British Plants. New Phytol. 39:17-32.

McNeill, J.; Dore, W.G. 1976 [1977]. Taxonomic and nomenclatural notes on Ontario grasses. Nat. Can. (Qué.) 103:553-567.

Moore, D.M.; Doggett, M.C. 1976. Pseudovivipary in Fuegian and Falkland Islands grasses. Br. Antarct. Surv. Bull. 43:103-110.

Mosquin, T.; Hayley, D.E. 1966. Chromosome numbers and taxonomy of some Canadian Arctic plants. Can. J. Bot. 44:1209-1217.

Mulligan, G.A.; Porsild, A.E. 1970. IOPB chromosome number reports XXV. Taxon 19:102-113.

Myers, W.N. 1947. Cytology and genetics of forage grasses. Bot. Rev. 13: 319-421.

Nygren, A. 1950. A preliminary note on cytological and embryological studies in arctic Poeae. Hereditas 36:231-232.

Pavlick, L.E. 1983a. Notes on the taxonomy and nomenclature of Festuca occidentalis and $F$. idahoensis. Can. J. Bot. 61:337-344.

Pavlick, L.E. 1983b. The taxonomy and distribution of Festuca idahoensis in British Columbia and northwestern Washington. Can. J. Bot. 61:345-353.

Pavlick, L.E. 1983c. Festuca viridula Vasey (Poaceae): Reestablishment of its original lectotype. Taxon 32:117-119.

Pavlick, L.E. 1984. Studies on the Festuca ovina complex in the Canadian Cordillera. Can. J. Bot. 62:2448-2462.

Pavlick, L.E. 1985. A new taxonomy of the Festuca rubra complex in northwestern North America, with emphasis on British Columbia. Phytologia 57:1-17.

Pavlick, L.E.; Looman, J. 1984. Taxonomy and nomenclature of rough fescues, Festuca altaica, $F$. campestris ( $F$. scabrella var. major), and $F$. hallii, in Canada and the adjacent part of the United States. Can. J. Bot. 62:1739-1749.

Pils, G. 1985. Das Festuca vivipara problem in den Alpen. Plant Syst. Evol. 149:19-45.

Piper, C.V. 1906. North American species of Festuca. Contrib. U.S. Natl. Herb. 10:1-48.

Polunin, N. 1940. Botany of the Canadian Eastern Arctic, Pt. 1. Natl. Mus. Can. Bull. 92. (Biol. Ser. 24). 408 p. 
Porsild, A.E. 1951. Botany of the southeastern Yukon adjacent to the Canol Road. Natl. Mus. Can. Bull. 121. 400 p.

Porsild, A.E. 1966. Contributions to the flora of southwestern Yukon Territory. Natl. Mus. Can. Bull. 216. 86 p.

Porsild, A.E.; Cody, W.J. 1980. Vascular plants of continental Northwest

Territories, Canada. Natl. Mus. Nat. Sci., Ottawa, Ont. 666 p.

Robson, M.J. 1967. A comparison of British and North African varieties of tall fescue (Festuca arundinacea). I. Leaf growth during winter and effects on it of temperature and day length. J. Appl. Ecol. 4:475-478.

Rydberg, P.A. 1905. Studies on the Rocky Mountain flora. 15. Bull. Torrey Bot. Club 32:597-610.

Rydberg, P.A. 1909. Studies on the Rocky Mountain flora. 19. Bull. Torrey Bot. Club 36:531-541.

Saint-Yves, A. 1925. Contribution à l'étude des Festuca (subgen. Eu-Festuca) de l'Amérique du Nord et du Mexique. Candollea 2:229-316.

Sampson, K. 1933. The systematic infection of grasses by Epichloe typhina (Pers.) Tul. Trans. Br. Mycol. Soc. 18:30-47.

Scoggan, H.J. 1978. The flora of Canada. Part II. Natl. Mus. Nat. Sci. (Ott.) Publ. Bot. $7: 93-545$.

Sharman, B.C. 1945. Leaf and bud initiation in the Gramineae. Bot. Gaz. 106:269-289.

Siplivinskii, V.N. 1973. Viviparous fescues (Festuca L.) of Siberia outside of the Arctic. Novst. Syst. Vyssh. Rast. 10:11-18 [in Russian].

Smoliak, S.; Adams, B.W.; Schuler, B.G.; Wroe, R.A.; Klumph, S.G.; Willms, W.D. 1985.

Forage production on selected native prairie sites in southern Alberta. Agric. Can. Tech. Bull. 1985-3E. 46 p.

Taylor, R.L.; Mulligan, G.A. 1968. Flora of the Queen Charlotte Islands. Part 2. Cytological aspects of the vascular plants. Can. Dep. Agric. Res. Branch Monogr. 4, part 2. $148 \mathrm{p}$.
Terrell, E.E. 1979. Taxonomy, morphology and phylogeny. Pages 31-97 in Buckner, R.C.; Bush, L.P.eds. Tall fescue. Am. Soc. Agronomy, Crop. Sci. Soc. Am., and Soil Sci. Soc. Am., Madison, Wis.

Toynbee, K. 1987. Prolific flowering year for Plains Rough Fescue at the Kernen Prairie. Blue Jay 45:142-143.

Tzvelev, N.N. 1971. On the taxonomy and phylogeny of the genus Festuca L. of the U.S.S.R. flora. I. The system of the genus and the main trends of evolution. Bot. Zh. (Leningr.) 56:1252-1262 [in Russian].

Tzvelev, N.N. 1972a. On the taxonomy and phylogeny of the genus Festuca L. of the U.S.S.R. flora. II. Evolution of the subgenus Festuca. Bot. Zh. (Leningr.) 57:161-172 [in Russian].

Tzvelev, N.N. 1972b. Genus Festuca in USSR. Novst. Sist. Vyssh. Rast. 9:15-46 [in Russian].

Tzvelev, N.N. 1976. Poaceae URSS. Nauka, Leningrad. 788 p. [in Russian] and Grasses of the Soviet Union. Zlaki SSSR. Nauka, Leningrad, Parts 1 and 2. Published for Smithsonian Institution Libraries and National Science Foundation, Washington, DC, by Oxonian, New Delhi (1983).

Vasey, G. 1893a. Descriptions of new or noteworthy grasses from the United States. Contrib. U.S. Natl. Herb. 1:267-280.

Vasey, G. 1893b. Grasses of the Pacific Slope including Alaska and the adjacent islands. Bull. U.S. Dep. Agric. Div. Bot. 13 Part 2.

Voss, E.G. 1972. Michigan flora. Part 1. Cranbrook Inst. Sci., Bloomfield, Mich. and Univ. Mich. Herb., Ann Arbor, Mich. 488 p.

Watson, L.; Aiken, S.G.; Dallwitz, M.J.; Lefkovitch, L.P.; Dubé, M. 1986. Canadian grass genera: Keys and descriptions in English and French from an automated data bank. Can. J. Bot. 64:53-70.

Watson, L.; Dallwitz, M.J. 1988. Grass genera of the World. Aust. Nat. Univ., Canberra.

White, J.F., Jr. 1987. The widespread distribution of endophytes in the Poaceae. Plant Dis. 71:340-342. 
White, J.F., Jr.; Cole, G.T. 1985. Endophytehost associations in forage grasses. I.

Distribution of fungal endophytes in some species of Lolium and Festuca. Mycotaxon 77:323-327.

White, J.F., Jr.; Cole, G.T. 1986. Endophytehost associations in forage grasses. IV. The endophyte of Festuca versuta. Mycologia 78:102-107.

White, J.F., Jr.; Cole, G.T.; Morgan-Jones, G. 1987. Endophyte-host associations in forage grasses. VI. A new species of Acremonium isolated from Festuca arizonica. Mycologia 79:148-152.
Woodward, W.U.W.; Frakes, R.V. 1977. Meiotic irregularities in tall fescue genotypes and their $F_{1}$ hybrids. Oreg. Agric. Exp. Stn. Tech. Bull. 139:1-56.

Wycherley, P.S. 1953a. Proliferation of spikelets in British grasses. I. The taxonomy of the viviparous races. Watsonia 3:41-56.

Wycherley, P.S. $1953 b$. The distribution of viviparous grasses in Great Britain. J. Ecol. 41:275-288. 


\section{Appendix}

Basic characteristics examined in the compilation of species descriptions

Characteristic Description of state Example species Figure reference

\begin{tabular}{|c|c|c|c|}
\hline Plant color & $\begin{array}{l}\text { Yellowish green } \\
\text { Bluish gray green } \\
\text { Deep green }\end{array}$ & & \\
\hline Plant height & $\begin{array}{l}1-30 \mathrm{~cm} \text { (arctic and } \\
\text { alpine taxa) } \\
>30 \mathrm{~cm}\end{array}$ & & \\
\hline $\begin{array}{l}\text { Habit at base } \\
\text { of plant }\end{array}$ & $\begin{array}{l}\text { Caespitose or densely tufted } \\
\text { Not caespitose or densely tufted }\end{array}$ & $\begin{array}{l}\text { F. altaica } \\
\text { F. subuliflora }\end{array}$ & \\
\hline $\begin{array}{l}\text { Color at base } \\
\text { of plant }\end{array}$ & $\begin{array}{l}\text { Purplish with anthocyanin } \\
\text { Not purplish with anthocyanin }\end{array}$ & & \\
\hline $\begin{array}{l}\text { Rhizomes or } \\
\text { stolons }\end{array}$ & $\begin{array}{l}\text { Present } \\
\text { Absent }\end{array}$ & $\begin{array}{l}\text { F. rubra } \\
\text { F. saximontana }\end{array}$ & \\
\hline Tiller bases & $\begin{array}{l}\text { Stiffly erect } \\
\text { Not stiffly erect, loosely } \\
\text { curving or decumbent }\end{array}$ & $\begin{array}{l}\text { F. idahoensis } \\
\text { F.rubra }\end{array}$ & \\
\hline $\begin{array}{l}\text { Culm internode } \\
\text { vestiture }\end{array}$ & $\begin{array}{l}\text { Glabrous } \\
\text { Scaberulous, scabrous, } \\
\text { or pubescent }\end{array}$ & F. baffinensis & \\
\hline Culm nodes & $\begin{array}{l}\text { Exposed } \\
\text { Never exposed }\end{array}$ & $\begin{array}{l}\text { F. richardsonii } \\
\text { F. campestris }\end{array}$ & \\
\hline New shoots & $\begin{array}{l}\text { Arising from within existing } \\
\text { sheaths } \\
\text { Arising outside or breaking } \\
\text { through the base of existing } \\
\text { sheaths }\end{array}$ & & $\begin{array}{l}\text { Plate 1, Figs. 3-4 } \\
\text { Plate 1, Figs. 1-2 }\end{array}$ \\
\hline $\begin{array}{l}\text { Sheaths of } \\
\text { vegetative } \\
\text { shoots }\end{array}$ & $\begin{array}{l}\text { Closed half or more } \\
\text { of their length } \\
\text { Open half or more } \\
\text { of their length }\end{array}$ & $\begin{array}{l}\text { F.rubra } \\
\text { F. saximontana }\end{array}$ & \\
\hline Sheaths & $\begin{array}{l}\text { Keeled } \\
\text { Rounded }\end{array}$ & & \\
\hline
\end{tabular}




\begin{tabular}{lll} 
Characteristic & Description of state & Example species \\
\hline $\begin{array}{l}\text { Sheaths } \\
\text { persistence }\end{array}$ & $\begin{array}{l}\text { Not prominent at base of plant } \\
\text { Prominent at base of plant, } \\
\text { persisting for more than 1 y } \\
\text { (marescent) }\end{array}$ & $\begin{array}{l}\text { F. subverticillata } \\
\text { F.campestris }\end{array}$ \\
\hline
\end{tabular}

Dead sheaths On drying splitting at membranous tissue between

veins (fibrillose)

Remaining entire, not conspicuously splitting between veins

$\begin{array}{ll}\text { Sheath } & \text { Glabrous } \\ \text { pubescence } & \text { Glabrescent } \\ & \text { With trichomes }\end{array}$

Auricles

Clawlike

$F$. gigantea

Auricle position with distinct

$F$. hallii, $F$. idahoensis erect swelling

Auricle position rounded, without distinct swelling

F. hyperborea, $F$. occidentalis

Auricle

With ciliate trichomes

F. arundinacea

trichomes

Auricle position without ciliate trichomes

F. pratensis

Ligule length

$0.1-0.5 \mathrm{~mm}$

$>0.5 \mathrm{~mm}$

Ligule

pubescence

Erose, ciliate

Without cilia

Blade texture of

Erect, stiffish mature leaf

More or less lax

F. campestris

blade

Blade shape

Adaxial blade vestiture

Abaxial blade vestiture
Usually plicate Plicate or flat

Always flat

Glabrous

With trichomes

Glabrous

With trichomes
F. subverticillata

F. saximontana

F. subulata

$F$. gigantea

F. campestris

F. brachyphylla

$F$. lenensis 
Basic characteristics examined in the compilation of species descriptions (continued)

Characteristic

Description of state

Example species

Figure reference

Width at widest $\quad<2 \mathrm{~mm}$

point of cross $\quad>2 \mathrm{~mm}$

Plate 3, position 1

section

Length of vertical $\quad<0.75 \mathrm{~mm}$

Plate 3, position 2

line between $\quad \geq 0.75 \mathrm{~mm}$

midrib adaxial

epidermis and

most distal cell in a

plicate leaf

Total number of large

Plate 3

and small

vascular bundles

in a plicate

leaf

Adaxial to

abaxial

sclerenchyma

strands

Development of sclerenchyma tissue in plicate leaves

Character of sclerenchyma strands

Panicle shape

Panicle length
Present

Absent

Poorly developed, usually only at outer leaf margin and midrib, along $<10 \%$ of leaf surface

Well-developed, present opposite large bundles, always along $>10 \%$ of margin

In discrete, relatively narrow strands opposite vascular bundles; 3 or more welldefined ribs

In broad strands or marginally continuous; with or without well-defined ribs

F. saximontana, $F$. filiformis

F. brachyphylla

F. campestris

F. altaica,

F. arundinacea

Plate 3

F. rubra

Branches erect (stiffish, usually $F$. brachyphylla each branch $<2 \mathrm{~cm}$ long)

Branches spreading (at least some branches $>2 \mathrm{~cm}$ long)

$\leq 5 \mathrm{~cm}$

$>5 \mathrm{~cm}$ 
Basic characteristics examined in the compilation of species descriptions (continued)

\begin{tabular}{|c|c|c|}
\hline Characteristic & Description of state & Example speci \\
\hline $\begin{array}{l}\text { Number of } \\
\text { branches } \\
\text { at lowest } \\
\text { panicle node }\end{array}$ & $\begin{array}{l}1 \text { or } 2 \\
3 \text { or more branches }\end{array}$ & F. subuliflora \\
\hline $\begin{array}{l}\text { Rachis branch } \\
\text { shape in cross } \\
\text { section }\end{array}$ & $\begin{array}{l}\text { Rounded } \\
\text { Angular }\end{array}$ & \\
\hline Rachis vestiture & $\begin{array}{l}\text { With trichomes mainly on } \\
\text { ridges } \\
\text { With trichomes over entire } \\
\text { surface }\end{array}$ & \\
\hline Callus & $\begin{array}{l}\text { Callus elongated so that } \\
\text { rachilla appears jointed } \\
\text { between florets } \\
\text { Callus not elongated, short }\end{array}$ & F. subuliflora \\
\hline $\begin{array}{l}\text { Spikelet length } \\
\text { range }\end{array}$ & $\begin{array}{l}\leq 6 \mathrm{~mm} \\
>6 \mathrm{~mm}\end{array}$ & \\
\hline $\begin{array}{l}\text { Number of } \\
\text { fertile florets } \\
\text { per spikelet }\end{array}$ & $\begin{array}{l}3 \text { or fewer } \\
4 \text { or more }\end{array}$ & \\
\hline $\begin{array}{l}\text { Glume length } \\
\text { relative } \\
\text { to first } \\
\text { lemma }\end{array}$ & $\begin{array}{l}\text { Much shorter } \\
\text { As long, or almost as long, as } \\
\text { first lemma }\end{array}$ & $\begin{array}{l}F . \text { baffinensis } \\
F . \text { hallii }\end{array}$ \\
\hline $\begin{array}{l}\text { Relative length } \\
\text { of glumes }\end{array}$ & $\begin{array}{l}\text { Subequal } \\
\text { Unequal }\end{array}$ & $\begin{array}{l}\text { F. hallii } \\
\text { F. altaica }\end{array}$ \\
\hline $\begin{array}{l}\text { Number of veins } \\
\text { in lower glume }\end{array}$ & $\begin{array}{l}1 \\
2 \text { or more }\end{array}$ & \\
\hline $\begin{array}{l}\text { Lower glume } \\
\text { length }\end{array}$ & $\begin{array}{l}1-4 \mathrm{~mm} \\
>4 \mathrm{~mm}\end{array}$ & \\
\hline $\begin{array}{l}\text { Number of veins } \\
\text { in upper glume }\end{array}$ & $\begin{array}{l}1-3 \\
4 \text { or more }\end{array}$ & \\
\hline $\begin{array}{l}\text { Upper glume } \\
\text { length }\end{array}$ & $\begin{array}{l}1-5 \mathrm{~mm} \\
>5 \mathrm{~mm}\end{array}$ & \\
\hline
\end{tabular}

Number of

branches

at lowest

shape in cross

Rachis vestiture

ridges

With trichomes over entire

between florets

Callus not elongated, short

Much shorter

As long, or almost as long, as

first lemma

Subequal

F. hallii

F. altaica

(continued) 


$\begin{array}{ll}\text { Glume vestiture } & \begin{array}{l}\text { Glabrous } \\ \text { Scaberulous or puberulent }\end{array} \\ \begin{array}{l}\text { Position of } \\ \text { glume }\end{array} & \begin{array}{l}\text { Glume vestiture at apex only } \\ \text { Gestiture }\end{array} \\ \text { outer surface }\end{array}$

Glume margins Glume margins erose, ciliate Glume margins entire

$\begin{array}{ll}\begin{array}{l}\text { Lemma } \\ \text { venation }\end{array} & \begin{array}{l}5 \text { distinc } \\ \text { Nerveles } \\ \text { only cent }\end{array} \\ \begin{array}{l}\text { Lemma } \\ \text { vestiture }\end{array} & \begin{array}{l}\text { Glabrous } \\ \text { With tric }\end{array} \\ \begin{array}{l}\text { Position of } \\ \text { lemma } \\ \text { vestiture }\end{array} & \begin{array}{l}\text { On upper } \\ \text { Similar }\end{array} \\ \text { Lemma length } & 2-7 \mathrm{~mm} \\ & >7 \mathrm{~mm} \\ & \leq 2 \mathrm{~mm} \\ \text { Lemma awn } & >2 \mathrm{~mm}\end{array}$

Palea vestiture Distinctly pubescent between keels

Glabrous (not distinctly pubescent) between keels

Lodicules Without marginal teeth With one or more marginal teeth

$$
\begin{aligned}
& \text { F. altaica } \\
& \text { F. campestris, } \\
& \text { F. hallii } \\
& \text { F. subverticillata } \\
& \text { F. richardsonii }
\end{aligned}
$$

F. arundinacea

F. hallii
Lodicule trichomes

Anther length
Absent

One or more marginal trichomes

$0.2-1.5 \mathrm{~mm}$ $>1.5 \mathrm{~mm}$
Plate 4, Figs. 1-3

Plate 4, Figs. 4-6

Plate 5, Fig. 5

Plate 5, Fig. 5

(continued) 
Basic characteristics examined in the compilation of species descriptions (concluded)

Characteristic

Description of state

Top of anthers lying at about one-third of the length of paleas

or less

Top of anthers lying at about

half the length of paleas

Top of anthers lying at more than half the length of paleas

Ovary

pubescence

Ovary apex

pubescence

density
Apex glabrous

Apex pubescent

Apex with fewer than

20 trichomes

Apex with more than

20 trichomes
Example species

F. baffinensis

F. campestris

Figure reference

Plate 5, Fig. 1

Plate 5, Figs. 2-5

Plate 5, Fig. 5

Plate 5, Figs. 2-3

Chromosome number

Northern

distribution

Southern

Canadian

distribution
Greenland

Franklin District

Keewatin District

Mackenzie District

Yukon

Alaska

Labrador

Newfoundland

Nova Scotia

Prince Edward Island

New Brunswick

Quebec

Ontario

Manitoba

Saskatchewan

Alberta

British Columbia

Status in

Canada

Habitat
Native grass

Established introduced species

Arctic or alpine

Forest or woodland

Range, prairie, or dry habitats

Eastern or western meadows

Wet habitats

Saline habitats

Cultivated crop

Cultivated ornamental

Limited, probably accidental introduction

Grown experimentally 


\section{Index}

Adopted names are set in boldface. Synonyms are set in light italics. Principal entries appear in boldface; figure page numbers are in italics; and the notation $k$ after a number indicates that the name occurs in a key.

Acremonium coenophialum Morgan-Jones \& Gams 5

Agropyron spicatum (Pursh) Scribner \& J.G. Smith 44

Balansiae (fungi) 5

bearded fescue $\mathbf{6 5}$

$\times$ Bromofestuca cojocnensis Prodan 3

Bromus L. 2

giganteus L. 37

Pnigma Dumortier (section) 2

Chewing's fescue 1,58

Claviceps Tul. 5

creeping red fescue complex $1,3,57-58$

crinkle awn fescue 65,67

Dactylis glomerata L. 58

Dover grass $\mathbf{5 3}$

English bluegrass $\mathbf{5 3}$

Epichloe typhina (Pers.) Tul. 5

Ergot-see Claviceps

\section{Festuca}

altaica Trinius in Ledebour $1,2,12,14 k, 20,21,33,78,103,105,106$, 107, map 1

ssp. hallii (Vasey) Harms 39

subvar. hallii (Vasey) Saint-Yves 39

var. major (Vasey) Gleason 33

f. pallida Jordal 21

ssp. scabrella (Torrey in Hooker) Hultén 33

var. scabrella (Torrey in Hooker) Breitung 33

f. vivipara Jordal 21

ambigua Vasey 67

americana (Persoon) F.G. Dietrich 53

arundinacea Schreber $2,3,5,10,16 k, 22,23-24,53,104,105,107$, map 2 hybrids 3

$\times$ aschersoniana Dorfler 3,24

aucta Kreczetowicz \& Bobrov 58

auriculata Drobov 47

ssp. choinobia (Egorova \& Siplivinsky) Tzvelev 47

f. pilosa Vodopjanova 47

baffinensis Polunin $1,2,11,17 k, 26,27,29,78,103,106,108$, map 3

$\times F$. brachyphylla 76 
brachyphylla Schultes \& Schultes fil. 1, 2, 11, 18k, 27, 28, 29, 31, 41, 47, 49,

$61-62,78,104,105, \operatorname{map} 4$

$\times F$. baffinensis 76

ssp. saximontana (Rydberg) Hultén 61

Breviaristatae Krivot (section) 1, 2,

brevifolia R. Brown 29

var. arctica Saint-Yves subvar. pubiculmis Saint-Yves 27

var. endotera Saint-Yves 49

var. utahensis Saint-Yves 49

brevipila Tracey 71

brevissima Jurtzev $1,2,19 k, 29,30,31,41,47,78$, map 5

f. pallida (Holmen) Frederiksen 31

campestris Rydberg $2,14 k, 21,32,33,39,44,78,103,104,105,107$,

108 , map 6

canadensis Alexeev 61-62

capillata Lamark 35

confinis ssp. rabiosa Piper 39

$\times$ czarnohorensis Zapalowicz 3

denticulata Beal 67

diffusa Dumort 58

doreana Looman 33

duriuscula auct. 71

elatior L. 23-24, 53

ssp. arundinacea (Schreber) Čelakovský 23

var. arundinacea (Schreber) Wimmer 23

ssp. pratensis (Hudson) Hackel 53

var. pratensis (Hudson) A. Gray 53

extremiorientalis Ohwi 65

Festuca (subgenus) 2, 24

filiformis Pourret $2,3,16 k, 34,35,78,105$, map 7

hybrids 3

$\times$ flischeri Rohlena 3

frederikseniae Alexeev 75

gigantea (L.) Villars $2,3,10,15 k, 36,37,104$, map 8

hybrids 3

$\times$ gigas Holmberg 3

hallii (Vasey) Piper 2, 10, 15k, 21,33, 38, 39, 78, 104, 106, 107, map 9

$\times$ herocynica Wien 4

howelli Hackel in Beal 73

hyperborea Holmen ex Frederiksen $1,2,4,10,19 k, 27,29,31,40,41,78$, 104, map 10

hybrids 4

idahoensis Elmer $1,2,9,11,17 k, 42,43-44,51,62,78,103,104$, map 11

var. roemeri Pavlick 44

ingrata (Hackel in Beal) Rydberg 43

jenseni Gjaerevoll \& Ryvarden 29

jonesii Vasey 65

lenensis Drobov $1,2,10,17 k-18 k, 31,46,47,78,104$, map 12

Leucopoa (Grisebach) Hackel (subgenus) 2

longifolia Thuillier 71

minutiflora Rydberg $1,2,11,18 k, 29,48,49,78$, map 13

$\times$ moyana Erdner 3

nigrescens Lamark 58

nutans auct. 69 
obtusa Biehler 69,78

f. pilosifolia Dore 69

Obtusae Alexeev (subgenus) 2

occidentalis Hooker $1,2,10,11,12,17 k, 43,50,51,78,104$, map 14

var. ingrata (Hackel in Beal) Boivin 43

ovina L. 13, 71

ssp. alaskana Holmen 31, 47

var. brachyphylla (Schultes \& Schultes fil) Piper 29

var. capillata (Lamark) Alefeld 35

var. columbiana Beal 43

complex $2,3,13,43,75-76,78$

var. duriuscula auct. 71

ssp. ingrata (Hackel in Beal) Piper 43

var. ingrata Hackel in Beal 43

var. minutiflora (Rydberg) Howell 49

var. oregona Hackel in Beal 43

var. polyphylla Vasey in Beal 51

ssp. saximontana (Rydberg) Saint-Yves 61

var. saximontana (Rydberg) Gleason 61

var. tenuifolia (Sibthorp) Roemer \& Schultes 35

var. vivipara $\mathrm{L} .75$

Plantynia (Dumortier) Tzvelev (section) 2

pratensis Hudson $2,4,10,16 k, 24,52,53,105$, map 15

hybrids 4

prolifera (Piper ex Robinson) Fernald 57

pseudovina auct. 61

purpusiana (Saint-Yves) Tzvelev 61-62

richardsonii Hooker $2,3,4,16 k, 41,54,55,57,78,103,107$, map 16

hybrids 4

roemeri (Pavlick) Alexeev 43-44

rubra L. $\quad 2-3,4,5,6,8,9-11,16 k, 55,56,57-58,78,103,105$, map 17

ssp. arctica (Hackel) Govoruchin 3, 55, 57

ssp. aucta (Kreczetowicz \& Bobrov) Hultén $57-58$

f. pseudovivipara Pavlick 58

var. commutata Gaudin 58

complex $2-3,4,76$

cultivars 58

$\times F$. vivipara 75

hybrids 4

f. prolifera (Piper ex Robinson) Hylander 4

ssp. pruinosa (Hackel) Piper 57

ssp. richardsonii (Hooker) Hultén 55

var. glabrata Hultén 55

ssp. rubra 57,58

saximontana Rydberg $2,6,8,9,11,12,18 k, 29,35,43-44,60,61-62,78,103$, 104,105 , map 18

var. purpusiana (Saint-Yves) Frederiksen \& Pavlick 61-62

var. robertsiana Pavlick 62

var. saximontana $61-62$

scabrella Torrey in Hooker 21, 33

ssp. hallii (Vasey) W.A. Weber 39

var. major Vasey 33

Schedonorus (Beauvois) Koch (section) 2

Schedonorus (Beauvois) Peterman (subgenus) 2, 10, 24 


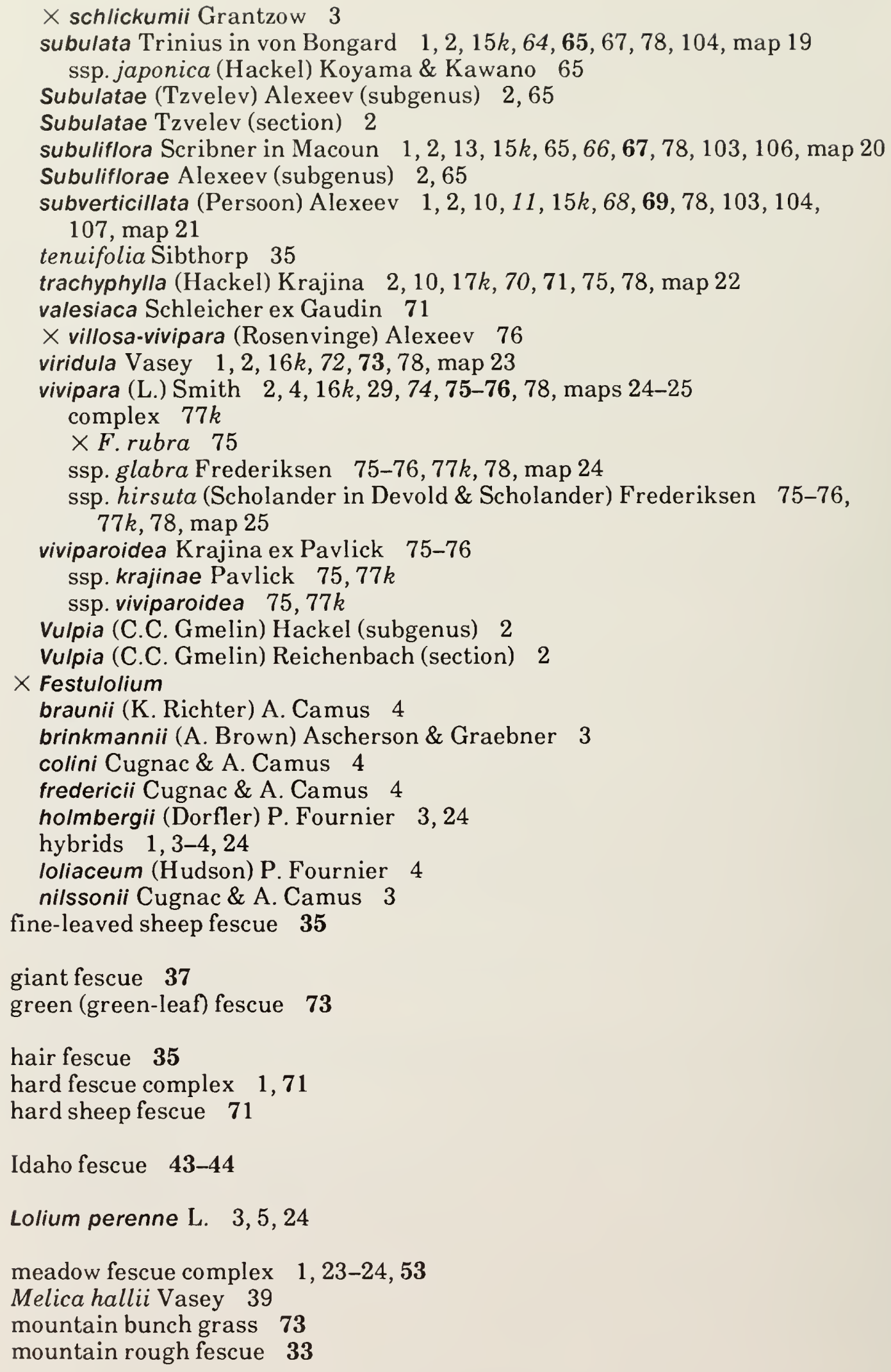




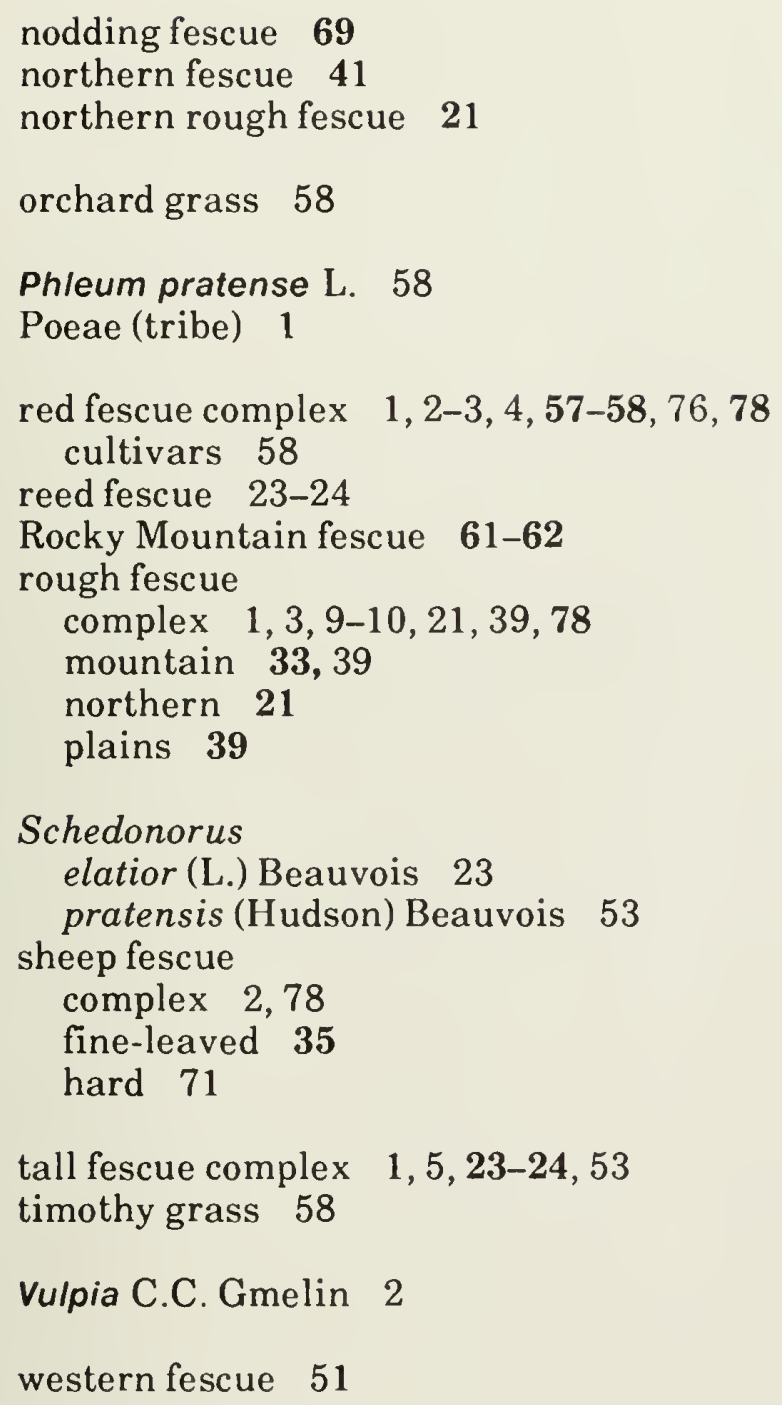






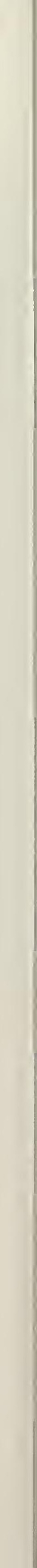



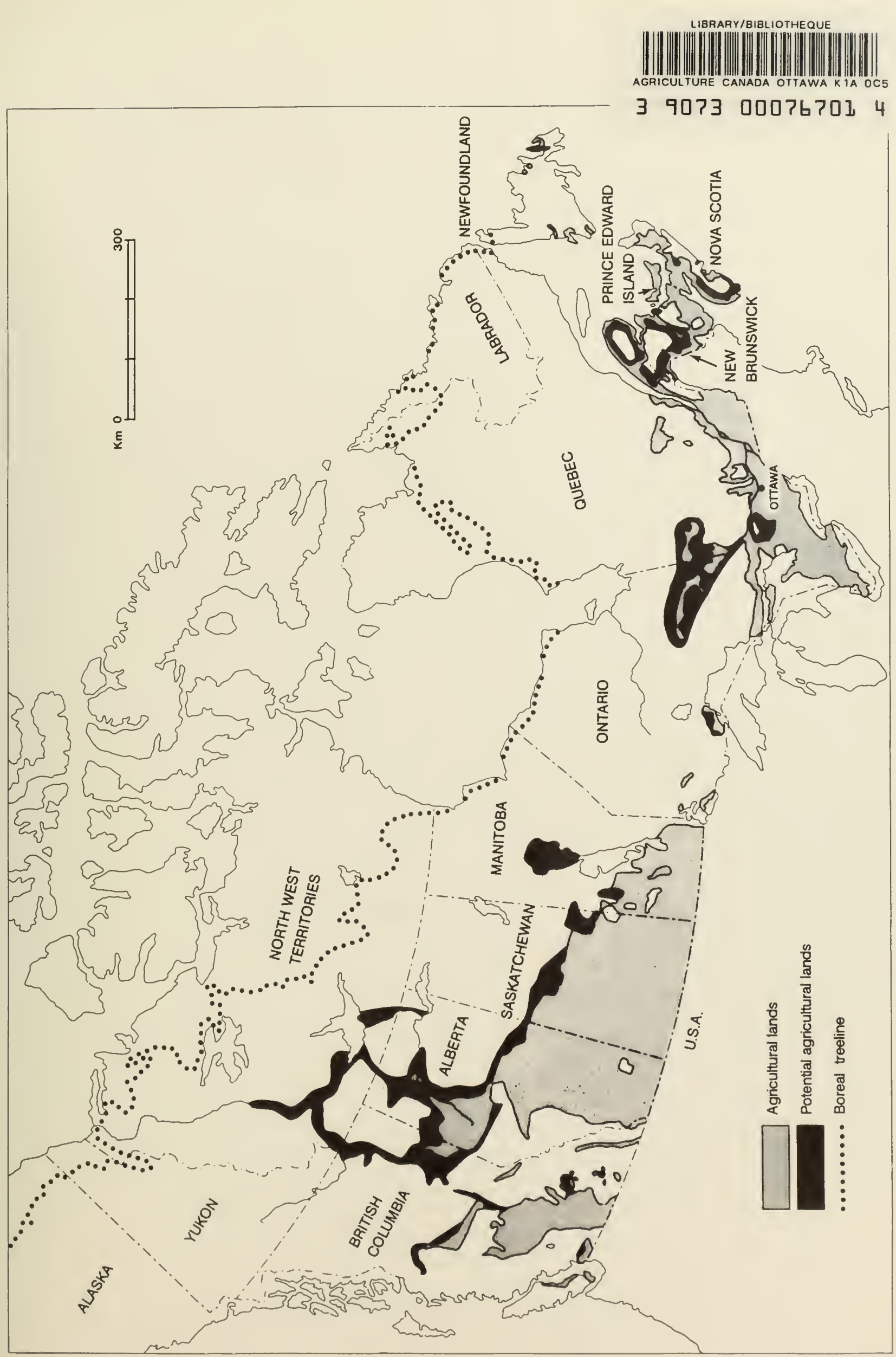


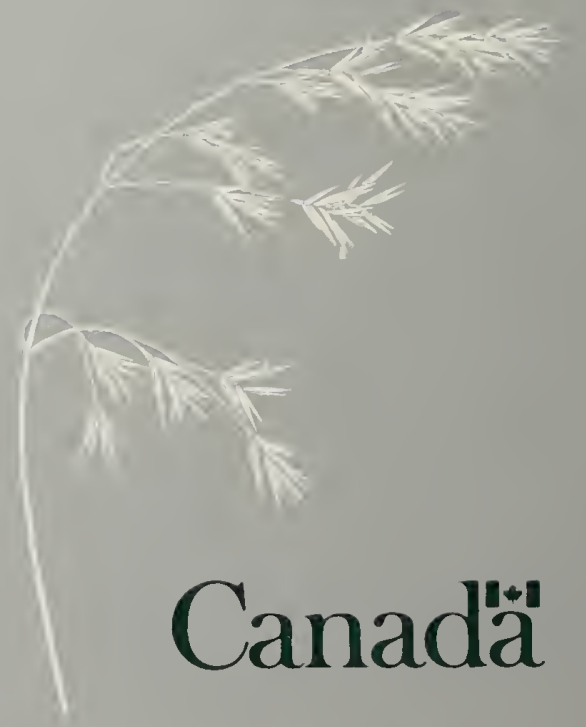

